\title{
Problems, threats and challenges for peace and conflict resolution
}

Edited by

Joanna Marszałek-Kawa Maria Ochwat 


\author{
Series \\ Asia-Pacific Library \\ Editor-in-Chief \\ Joanna Marszałek-Kawa
}

Secretary

Bartosz Ptotka

\begin{abstract}
The Editorial Board
Kamal M. Abdulla (Azerbaijan), Daulet L. Baideldinov (Kazakhstan), Marceli Burdelski (Poland), He Yaomin (China), Hassan A. Jamsheer (Poland), Vasyl Marchuk (Ukraine), Joanna Marszałek-Kawa (Poland), Miao Huashou (China), Vladimir I. Nifadiev (Kyrgyzstan), Ewa Oziewicz (Poland), Zdzistaw Puślecki (Poland), Akmal Saidov (Uzbekistan), Grażyna Strnad (Poland), Peter Vorel (Czech Republic)
\end{abstract}

\author{
Reviewers \\ Professor Renata Podgórzańska \\ Professor Andrzej Stelmach \\ Publishing editor: Daniel Kawa \\ Technical editing: Ryszard Kurasz \\ Proofreading: Team \\ Cover design: Krzysztof Galus \\ (c) Copyright by Wydawnictwo Adam Marszałek
}

All rights reserved. The book you have purchased is the work of the author and the publisher. No part of it may be reproduced in any manner whatsoever without permission in writing from the copyright owner. In case of brief quotations of the work do not change the contents and make sure to note whose it is

Toruń 2020

\title{
ISBN 978-83-8180-509-4
}

The $7^{\text {th }}$ International Asian Congress "Building the Future of the State: Tradition, Reality, Progress” - a task co-financed under contract no. DNK/SP/466246/2020 from the Ministry of Science and Education funds allocated to the dissemination of science

Sales Department: tel. +48 5666422 35, marketing@marszalek.com.pl

Adam Marszałek Publishing House, ul. Lubicka 44, 87-100 Toruń tel. +48 5666422 35, e-mail: info@marszalek.com.pl, www.marszalek.com.pl Printing House, ul. Warszawska 54, 87-148 Łysomice, tel. +48 566783478 


\section{Table of Contents}

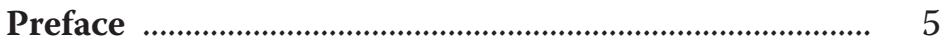

Phill Gittins, Sayako Aizeki-Nevins, Christine Odera, Alejandra Rodriguez, Daria Pakhomova, Laiba Khan Flipping the script: Youth perspectives on peace and war from five continents

\section{Anna Adamus Matuszyńska}

A new perspective on conflict resolution.

Does the concept of conflict resolution help

to resolve disputes in Asian countries?

\section{Monica A. Fennell}

Using peace and conflict analysis to spur innovation in access to justice in the U.S.

\section{Helen Tanner}

Searching for Peace: Finding Forgiveness

\section{Sudarat Tuntivivat}

Vocational Education for Sustainable Peace

in Southern Thailand 


\section{Vanessa Tinker}

The Role of Education in Turkey's Intractable

Conflict and Failed Peace Process

\section{Kishu Daswani}

The Citizenship (Amendment) Act 2019, India:

A Crisis of Statelessness

\section{Dickson Ogbonnaya Igwe}

Conflict of Interests and Demilitarisation Process 


\section{Preface}

President Ronald Reagan said: "Peace is not absence of conflict, it is the ability to handle conflict by peaceful means." The primary goals of international conflict resolution are to use means other than violence to settle both interstate and intrastate disputes, and to transform the relationships of disputing parties such that resort to violence is less likely in the future. It incorporates not only negotiation but moves beyond it and include education, training, improving intergroup relations, and creating intercultural awareness. War is often the cost of failure in international conflict resolution (ICR) efforts, making the stakes quite high for all concerned. The field of ICR came of age in the 1990s, but it blossomed after the fall of the Berlin Wall in 1991 and the end of the Cold War.

The book entitled "Problems, threats and challenges for peace and conflict resolution" is the fruit of collaboration of distinguished scientists and practitioners from different countries such as the United States, the United Kingdom, Columbia, Kenya, Nigeria, Thailand, India, Russia, and Poland, who present various issues concerning respect for peace and conflict resolution in the world. This publication is intended for scholars and professionals working in the field of security, peacekeeping and conflict resolution. The field is extremely dynamic, therefore we consider to continue the topic in further publications. 
Phill Gittins and his co-authors - Sayako Aizeki-Nevins, Christine Odera, Alejandra Rodriguez, Daria Pakhomova and Laiba Khan claim that most texts about peace, war, and youth are written by adults. The purpose of their article is for young people to produce their own reflections on their experience of peace and war. Using the words and ideas of young people, the article offers personal reflections on peace and war from the U.S., Kenya, Colombia, Russia, and India. The analysis centers on the main opportunities and barriers for building peace in the said contexts and what steps might be taken to move us toward a world beyond war.

Anna Adamus-Matuszyńska discusses a new perspective on conflict resolution. She wonders whether the concept of conflict resolution will help to resolve disputes in Asian countries? Conflict is a universal social phenomenon. Therefore, each society develops its own norms, rules, laws, and institutionalized forms leading to its resolution. Solving the conflict means revealing the causes of a given situation and choosing one of the many alternative options to organize the relations between the parties of the conflict situation. Conflict resolution is a process developed by researchers and practitioners to de-escalate and reconciliate difficult relationships between at least two parties for constructive settlement. The paper considers whether such an approach can be successfully practiced in the Asian countries, which are culturally, politically, socially, and ideologically diverse societies.

Monica Fennell talks about four main types of delivery models for civil legal assistance for low-income people in the U.S.: legal aid organizations with a staff attorney model, pro bono programs, self-represented litigant initiatives, and alternative dispute resolution programs. In her opinion 
these programs often fail to collaborate, resulting in low-income people who need legal help being bounced from place to place and increasing the time to reach resolution or increasing the number of people who give up on a resolution. Many of those who have access to justice programs are interested in increasing funding for access to justice, and they denigrate other models in order to promote their own. Using Johan Galtung's conflict analysis triangle can help break down the conflict to shed some light on how the conflict in access to justice delivery models can be resolved.

Helen Tanner explores forgiveness and its potential role within the peacebuilding arena, and also invites activists as peacebuilders to embrace forgiveness as a personal practice enabling us, as Ghandi suggested, "to be the change we wish to see in the world."

Sudarat Tuntivivat writes about vocational education for sustainable peace in Southern Thailand. The purpose of her research is to investigate the underlying conditions influencing the decisions of students to pursue vocational education for sustainable peace in southern Thailand. The article also offers some policy implications on vocational education for sustainable peace.

Vanessa Tinker discusses the role of education in Turkey's intractable conflict and failed peace process. Hopes of ending three decades of intractable conflict that has impeded the country's modernization and democratization efforts and resolving the Kurdish Question were dashed in 2015 when the peace process collapsed and violence renewed between the Republic of Turkey led by the Justice and Development Party (AKP) and the Kurdistan Workers' Party (PKK). Literature has covered different aspects of Turkey's peace process and identified reasons for its collapse, but has paid scant atten- 
tion to its crucial dimension - education. This article seeks to address this overlooked and yet vital issue.

Kishu Daswani writes about the citizenship (amendment) act 2019, India: a crisis of statelessness. The author says that in theory, India is a secular democracy. In practice, it is becoming to be decidedly less so. The controversial Citizenship (Amendment) Act, 2019 enacted by the right wing government has been seen as exclusionary, discriminatory and plain neglectful of the considerable Muslim population that India is home to. This paper explores the tenuous ways in which it has radically changed the nature of citizenship laws in India. It then focuses on its socio-political necessity, brought about by illegal mass migration in Assam. More worryingly, the CAA introduces religion as a qualifier to Indian citizenship in an unprecedented departure from the laws hitherto formulated.

Dickson Ogbonnaya Igwe analyses conflict of interests and demilitarization process against insurgency in sub-Saharan Africa. In his view demilitarization explores human capital, capacity and capability to unleash creative engagement and innovative compromise that provides common ground that does no harm to the interest of the contending parties. Therefore the author affirms the need for demilitarization that deepens sustainable human security option.

We encourage you to read the book.

Joanna Marszałek-Kawa

Maria Ochwat 


\section{Phill Gittins}

Education Director for World BEYOND War, the United Kingdom Sayako Aizeki-Nevins

Member of the World BEYOND War Youth Network, the United States

\section{Christine Odera}

Member of the World BEYOND War Youth Network, Kenya

\section{Alejandra Rodriguez}

Member of the World BEYOND War Youth Network,

\section{Colombia}

\section{Daria Pakhomova}

Member of the World BEYOND War Youth Network, Russia

\section{Laiba Khan}

Member of the World BEYOND War Youth Network, India

\section{Flipping the Script: Youth Perspectives on Peace and War from Five Continents}

\section{Introduction}

Most texts about peace, war, and youth are written by adults. These works tend to speak about or for young people; they do not produce work that is written with, for, or by them. Such analyses tend to be decontextualized and top-down. This is problematic, not only because it can lead to a limited understanding of youth's lived experiences and situated knowledge(s) of peace and war, but also because it lends itself to a framing of young people as they "cannot represent themselves, they must be represented". ${ }^{1}$ Currently,

1 E. Said, Orientalism, London 1995. 
there is far too little acknowledgement in the peacebuilding literature that young people can and should produce their own accounts of peace and war, and even less reflection on what this looks like in practice. ${ }^{2}$

To address this gap, the main task of this chapter is to coauthor with young people. Rather than extracting information from youth to 'tell their stories' for them, we designed this work to flip the script, so that youth use their own words to speak for themselves and make their own cases about peace and war in the societies in which they live. In doing so, the chapter is based on the following premise: that all voices matter in the global discourse on war-to-peace transitions, and that more attention needs to be given to supporting young people to produce their own accounts of peace, war, and related issues. This chimes with Foucault's (2001) notion of 'parrhesia,", when parrhesia is understood as the capacity and need for all people to speak their truth with integrity.

The chapter proceeds in three main sections. The first section sets the scene by outlining how the chapter's contributions can be contextualized within broader debates in peacebuilding around youth agency, voice, and inclusion in peace work. It offers working definitions for peace, war, and youth, followed by some background information about the peace-war-youth nexus. It also raises the idea of youth as scholars - making the argument that young people should be supported to produce their accounts of peace and war - an

2 Notable exceptions include: S.B. Martin, J.H. Burbach, L.L. Benitez, I. Ramiz, Participatory action research and co-researching as a tool for situating youth knowledge at the centre of research, London Review of Education, 2019, Vol. 17 (3), pp. 297-313, DOI/doi.org/10.18546/LRE [access: 17.03.2005].

3 M. Foucault, Fearless speech, Los Angeles 2001. 
idea which is not, up until the present moment, part of the common peacebuilding discourse. The second section exemplifies this argument through the perspectives of the (young) co-authors of this chapter who reflect on issues of peace and war in the societies where they live. The first is from the U.S. (Sayako Aizeki-Nevins), the second from Kenya (Christine Odera), the third from Colombia (Alejandra Rodriguez), the fourth is from Russia (Daria Pakhomova), and the fifth is from India (Laiba Khan). The third section discusses what all of this implies for the scholarship and practice of peace and war more generally.

\section{A note on terminology}

The main task of this chapter is to provide a set of personal reflections on peace and war from the point of view of young people from five different contexts. Before proceeding directly to this task, it is necessary to define and discuss what is meant by 'peace' 'war', and 'youth'

The term 'peace' is understood here as both a means and an end - something that has inner (personal) and outer (social and political) dimensions and includes, but takes on much more, than the absence of war and direct violence. ${ }^{4}$ Specifically, the chapter makes a distinction between negative peace (the absence of direct violence and absence of the fear of violence) and positive peace (the presence of attitudes, institutions and structures that sustain a peaceful society). ${ }^{5}$

4 See: P. Gittins, Peace and peace education, for a more thorough overview of the different definitions of peace, [in:] Gittins, Velázquez-Castellanos, Peace and conflict in Bolivia, Bolivia 2016.

5 IEP (Institute for Economics and Peace), Global peace index, 2016, New York: IEP. 
By 'war' a commonly used definition is 1,000 or more "battlefield" related deaths. ${ }^{6}$ This definition does not include victims who die through indirect violence such as disease and famine. As such, we adopt a broad definition of war that includes, but goes beyond, what happens on the battlefields 'out there' in far-away countries. We include in our definition both the ongoing preparations for war and the remnants of war. The former refers to activities that are prepared in advance, such as the recruitment, training, and deployment of troops; the acquisition, storage, and distribution of arms and ammunition; and the making and legitimization of specific war plans. The latter refers to the aftermath of war including both the physical (malnutrition, illness, and disability) and the emotional downsides (post-traumatic stress disorder, depression, and anxiety). ${ }^{7}$

Regarding 'youth' there is no universally agreed upon definition of what constitutes a young person ${ }^{8}$. However, there are a number of commonly used definitions. For example, the UN and World Bank (2007) consider youth as the age between 15 and 25, in line with the "United Nations, General Assembly Resolution 50/81 of 13 March 1996. For the purposes of this chapter, we are using the concept 'youth' to refer to "those within the second and third decade of life".

6 T. Lotta, Wallensteen, Armed conflict, 1946-2012, "Journal of Peace Research" 2013, Vol. 50 (4), pp. 509-521.

7 V. Dennen, On war: Concepts, definitions, research data: A short literature review and bibliography, 2005.

8 Read more at: P. Gittins, Introduction, 2016, [in:] Gittins, VelázquezCastellanos, Peace and Conflict in Bolivia, Konrad Adenauer Foundation, 2016.

9 M.L.J., Lopes Cardozo, S. Higgins, M.L.J. Le Mat, Youth agency and peacebuilding: an analysis of the role of formal and non-formal education Synthesis report on findings from Myanmar, Pakistan, South Africa and Uganda. Research Consortium Education and Peacebuilding, Amsterdam, 2015. 


\section{The peace-war-youth nexus}

There is a lot to be said about the peace-war-youth nexus, but we will note three main things here.

First, peace is fundamental to human progress. Recent research shows that peace has become an essential ingredient for social, environmental, political, and economic development. ${ }^{10}$ The interrelationship between peace and development has led us to our present moment in which there is a broad consensus that "There can be no sustainable development without peace and no peace without sustainable development." ${ }^{11}$ The issue here is that the world is less peaceful today than at any time in the last 10 years ago and that we are now at a 30-year high in violence. The evidence shows that a major source of this violence is war, which brings us to our second point.

Second, many stories are told about war: that it is inevitable, just, necessary, and beneficial, ${ }^{12}$ or that it is immoral, endangers us, erodes civil liberties, promotes bigotry, wastes resources, threatens our environment, and impoverishes us. ${ }^{13}$ On balance, most agree that war is development in reverse. It

10 Read more at P. Gittins, The role of youth in peace and security, [in:] idem (ed.) A global security system: An alternative to war, $5^{\text {th }}$ ed. World BEYOND War, Charlottesville, 2020.

11 Bouzar K., No Peace, No Sustainable Development: A Vicious Cycle that We Can Break, United Nations Chronicle, www.un.org/en/ chronicle/article/no-peace-no-sustainable-development-vicious-cyclewe-can-break [access: 19.05.2021].

12 Myths, World BEYOND War, worldbeyondwar.org/myths/ [access: 19.05.2021].

13 Why, World BEYOND War, worldbeyondwar.org/why/ [access: 19.05.2021]. 
destroys lives, communities, and property; undermines economic well-being; and perpetuates the climate emergency. Some 180 million people died in wars in the 20th century. ${ }^{14}$ Today, over 1.5 billion people live in a community affected by war, violence, or high levels of crime, and over 526,000 people die each year as a result of violence or conflict; approximately one per minute. ${ }^{15}$ And, for the first time in history, worldwide displacement tops 70 million people, $90 \%$ of whom are fleeing war, violence, and persecution. ${ }^{16}$ Aside from the human costs, wars are devastating to the economy. Research shows that wars cost the world about \$10 trillion each year, or \$4 a day, every single day, for each person on the planet. ${ }^{17}$ This is money that could be better spent on healthcare, education, mitigating climate change, COVID-19 recovery, and so much more. Abolishing the institution of war will not only save lives and livelihoods. It may also help to save our planet, since militarism is a top contributor to the global climate crisis. ${ }^{18}$ The United States army, for example, is the world's biggest polluter. ${ }^{19}$

14 Introduction to World Beyond War, World BEYOND War, worldbeyondwar.org/video/ [access: 19.05.2021].

15 World Report on Violence and Health, World Health Organization Geneva, 2002, www.who.int/violence_injury_prevention/violence/ world_report/en/abstract_en.pdf [access: 19.05.2021].

16 Worldwide displacement tops 70 million, UN Refugee Chief urges greater solidarity in response, UNHCR, 2021, www.unhcr.org/ news/press/2019/6/5d03b22b4/worldwide-displacement-tops-70-million-un-refugee-chief-urges-greater-solidarity.html [access: 19.05.2021].

17 S. Auteserre, The frontlines of peace: An insider's guide to changing the world, Oxford 2021, www.visionofhumanity.org/wp-content/uploads/2021/01/EVP-2021-web-1.pdf [access: 19.05.2021].

18 The US military is a bigger polluter than more than 100 countries combined, Quartz, 2019, qz.com/1655268/us-military-is-a-bigger-polluter-than-140-countries-combined/ [access: 19.05.2021].

19 B. Neimark, O. Belcher, P. Bigger, The US military is a bigger 
Third, while debates on the most effective ways of transitioning from war to peace continue, there is no viable approach to ending war and sustaining peace that does not include the meaningful and full participation of young people. Gandhi and other world leaders have long argued that if we are to achieve real peace in the world then we have to start with children and youth. In theory, there are three main ways of looking at the role that youth play in peace work; that of victims of violence, that of preparators of violence, and that of peacebuilders. ${ }^{20}$ In reality, the role of youth in peace work has historically been on the margins of mainstream peacebuilding practice. As a result, young people tend to be seen (and see themselves) more as problems to be solved and less as solutions to today's problems. That being said, interest in the role of youth as a positive force for peace has grown rapidly in the last five years. This interest is influenced by the fact that young people (ages 15-25) are the largest and fastest growing demographic on the planet today ${ }^{21}$ with more than half of the population under the age of 25 . It is also influenced by the fact that one in four young people are subjected to violence. In recent years, new policy frameworks along with scholarly and programming interventions have influenced the delivery of youth peace work, including the call, among other things, to mainstream youth inclusion in

polluter than more than 100 countries combined, Quartz, 28.01.2019, qz.com/1655268/us-military-is-a-bigger-polluter-than-140-countriescombined/ [access: 19.05.2021].

20 Read more at: G. Simpson, The missing peace: Independent progress study on youth, peace and security, 2018, www.youth4peace.info/ UNSCR2250/Introduction [access: 19.05.2021].

21 World youth report 2018: Youth and the 2030 agenda for sustainable development, United Nations, 2019, New York, doi:10.18356/ 0c6f53e0-en [access: 19.05.2021]. 
all peace processes. These include three UN Security Council Resolutions on Youth, Peace, and Security (YPS), a global analysis from the UN, and a 2020 report by the UN Secretary-General. They also include a proliferation of research centers, working groups, programs, and projects dedicated to the global YPS agenda. These initiatives represent attempts to consider young people more as partners for peace and less as passive recipients of programming, victims, or perpetrators or violence. Acknowledging the progress made, there is a clear need to narrow the gap between rhetoric and reality when it comes to putting youth at the center of peacebuilding efforts. Youth have experienced, and continue to experience, what they describe as their 'violence of exclusion.22 The result is that young people too often remain untapped resources when it comes to the study and practice of peace.

For the purposes of this chapter, we highlight and respond to one feature of contemporary peacebuilding scholarly works which we think is sorely underdeveloped; that is, the role of young people as knowledge creators. The majority of texts on peace, war, and youth are written by university-based academics; hence while there is a wealth of literature calling for young people to 'tell their stories' there is a dearth of attention given to young people producing their own explanations or critical analyses of peace and war. Therefore, besides supporting young people to apply other people's peace knowledge to research and practice, much more can be done to also support young people to create and apply their own knowledge. But this means rethinking our notions and practices of scholarship, so that we can begin to look at young people as scholars.

22 See G. Simpson, The missing peace: Independent progress study on youth, peace and security, 2018. 
These are some of the factors that led us to write this chapter. Against this backdrop, the following section takes further the idea of youth as scholars. Specifically, it offers personal reflections on peace and war from the point of view of young people from five contexts, each providing a different perspective and together helping to paint a broader picture of what youth think are the main challenges and opportunities for peace and war in the societies where they live.

\section{Youth perspectives on peace and war in five different continents}

The five co-authors who are featured in this section are all part of the World BEYOND War Youth Network (WBWYN) - a global community of youth and youth-serving organizations working toward the abolishment of war and the establishment of just and sustainable peace. They write in different styles and come from different worldviews, but have all been involved in peacebuilding efforts in diverse contexts and studied peace-related matters in different educational settings. They were invited to co-author this chapter and provide an insider perspective on peace and war from the societies in which they live. More specifically, they were invited to articulate answers to the following questions, 'What are the main opportunities and barriers for building sustainable peace in your context?' and, 'What steps can be taken to move us toward a world beyond war?'

The chapter was written collaboratively over the space of five months. We began the process by discussing what the focus of the chapter might be, before crafting the questions to explore. As we moved through the writing process, 
the challenge became how to find a middle ground between enabling youth to tell their valuable inside stories, on the one hand, and ensuring that such work could be considered as legitimate scholarship, on the other. To this end, the first author, Phill, sent his co-authors advice on how to produce a quality text, including how to:

- Work towards developing explanatory accounts such as, "My country is this peaceful or violent because..." as opposed to descriptive accounts such as, "My country is peaceful or violent".

- Demonstrate critical engagement with their own and other people's thinking. Examples were given of how their accounts could be influenced by and grounded in the relevant literature.

Each co-author sent Phill drafts of their work for comment on conceptualization, form of expression, and editorial support. ${ }^{23}$ They were also invited to provide feedback on each other's work. The purpose of the following section is not to describe the complexities of peace and war in each context, but to bring new perspectives on the universal concerns of peace and war - written with and by youth about the localities in which they live. In brief, it aims to add to contemporary debates in the peacebuilding field and highlight the contributions of youth as scholars.

\section{Sayako Aizeki-Nevins on peace and war in the United States of America}

I am a high-school student from New York, United States of America (U.S.). For the past two years, I have worked

23 J. McNiff, Writing and doing action research, London, Sage 2014. 
on issues of climate and racial justice, which led me to the fields of peace-building and war abolition. Today, my main interests revolve around the intersections between climate change, militarism, and war. I pursue these interests through my work with the WBWYN.

The U.S. has the most-funded military in the world. Its military budget, an estimated $\$ 1.25$ trillion in total ${ }^{24}$, is greater than the next 10 countries combined. ${ }^{25}$ The U.S. also maintains about eight hundred military bases around the world. ${ }^{26}$ This spending and global presence is both a cause and a result of the U.S.' long history of violent conflict: the country has been engaged in war continuously since its founding. ${ }^{27}$ The dominant narrative in the U.S. is that the military preserves democracy, despite its actual role in supporting oppressive dictatorships ${ }^{28}$ and waging violent conflicts for fossil fuels. ${ }^{29}$ This narrative is perpetuated in

24 M. Smithberger, W. Hartung, Making sense of the \$1.25 trillion national security state budget, Project on Government Oversight, 7 May 2019, pogo.org/analysis/2019/05/making-sense-of-the-1-25-trillion-national-security-state-budget/ [access: 5.10.2021].

25 The United States spends more on defense than the next 10 countries combined, Peter G. Peterson Foundation, 15 May 2020, www.pgpf. org/blog/2020/05/the-united-states-spends-more-on-defense-than-thenext-10-countries-combined [access: 23.01.2021].

26 Hjelmgaard, Kim, 'A Reckoning Is Near': America Has a Vast Overseas Military Empire. Does It Still Need It?, "U.S. Today, Gannett Satellite Information Network”, 25.02.2021, www.U.S.today.com/in-depth/news/ world/2021/02/25/us-military-budget-what-can-global-bases-do-vscovid-cyber-attacks/6419013002/ [access: 28.02.2021].

27 S. Shah, The US Has Been at War 225 out of 243 Years since 1776, “The News International”, 9.01.2020, www.thenews.com.pk/print/ 595752-the-us-has-been-at-war-225-out-of-243-years-since-1776 [access: 20.02.2021].

28 N. Lakhani, Who Killed Berta Cáceres?: Dams, Death Squads, and an Indigenous Defender's Battle for the Planet, Verso Books, 2020.

29 N. Crawford, Pentagon Fuel Use, Climate Change, and the Costs 
many primary and secondary schools that teach a largely uncritical history of the country's role in global conflicts ${ }^{30}$ and allow the military to recruit students in schools. ${ }^{31}$ While this indoctrination of youth has posed a significant barrier to building a movement to resist militarism, it can be addressed through connecting peacebuilding efforts to the youth-led climate and racial justice movements.

Beginning in World War II, the U.S. government mobilized education as a tool to instill patriotism and "American values" in students. During the Cold War (1947-1991), those who taught content even remotely critical of American institutions were threatened and often fired. ${ }^{32}$ This legacy is visible today, as history textbooks spend little time discussing the harms of modern wars. Instead, many textbooks emphasize the role the U.S. military has played to uphold democracy around the globe by challenging communist threats. ${ }^{33}$

At the same time, recruiters in secondary schools use material incentives to attract students to the military. According to a 2017 Department of Defense poll, the majority

of War, "Costs of War Project", 13.11.2019, https://watson.brown.edu/ costsofwar/files/cow/imce/papers/2019/Summary_Pentagon\%20Fuel\%20 Use $\% 2$ C $\%$ 20Climate $\% 20$ Change $\% 2$ C $\% 20$ and $\% 20$ the $\% 20$ Costs $\% 20$ of $\% 20$ War\%20(1).pdf [access: 28.02.2021].

30 J. Loewen, Lies My Teacher Told Me: Everything Your American History Textbook Got Wrong, "The New Press", 2019.

31 A. Corcione, Why Poor Youth Are Targeted for Military Recruitment, “Teen Vogue”, 22.01.2019, www.teenvogue.com/story/the-military-targets-youth-for-recruitment [access: 23.01.2021].

32 C. Conner, C. Bohan, The Second World War's impact on the progressive educational movement: Assessing its role, Middle and Secondary Education Faculty Publications, 2014, scholarworks.gsu.edu/mse_facpub/74 [access: 23.01.2021].

33 J. Loewen, Lies My Teacher Told Me: Everything Your American History Textbook Got Wrong, “The New Press”, 2019. 
(eight-six percent) of teenagers responded that they would not be likely to serve in the military in the next few years. ${ }^{34}$ To address this, recruiters try to attract students by primarily targeting working-class school districts. They promote the incentives of free college or, for non-citizens, a path to citizenship that can come from military service with honorable discharge. In the past, recruiters have also used video games, such as virtual reality helicopter games, to create a sense of excitement and fun around military activities. ${ }^{35}$ These incentives not only cultivate a deceptively innocuous image of the military, but also take advantage of young people - especially undocumented youth, racial minorities, and those from working-class backgrounds. These practices, in addition to the biased curriculum, ensure that many young people are not equipped to participate critically in debates surrounding the U.S. military and war as a practice.

To work towards peace, globally and locally, it is imperative that young people mobilize against the war system. Since the War on Terror, there have been periods of mass mobilization against U.S. military involvement abroad, but the anti-war movement has increasingly lost its visibility since then. ${ }^{36}$ Even though the U.S. has been continually involved in military conflicts over the past twenty years, there

34 Spring 2017 Propensity Update, Office of People Analytics, 2017, jamrs.defense.gov/Portals/20/Futures-Survey-Spring-2017.pdf [access: 23.01.2021].

35 A. Corcione, Why Poor Youth Are Targeted for Military Recruitment, Teen Vogue, 22 Jan. 2019, www.teenvogue.com/story/the-military-targets-youth-for-recruitment [access: 23.01.2021].

36 M. Engler, Anti-War Movements, From Vietnam to Today, Morningside Center for Teaching Social Responsibility, 1.04.2017, www.morningsidecenter.org/teachable-moment/lessons/anti-war-movements-vietnam-today [access: 25.02.2021]. 
is little awareness or mobilization against this among young people; this is a major barrier to peace.

For the past couple of years, I have been organizing as a high school student around the climate crisis as well as racial injustice. Even though war and militarism are deeply intertwined with climate change and ecological devastation, war abolition is not raised as an issue in the movement for environmental justice. The U.S. military is the single largest institutional polluter in the world. ${ }^{37}$ To reach the goal of reducing global $\mathrm{CO} 2$ emissions by 15 million tons per year, the U.S. military must significantly reduce its greenhouse gas emissions, which is already over four times that goal annually. ${ }^{38}$ Despite this fact, many major environmental organizations, such as the Sierra Club, the Natural Resources Defense Council, and the Nature Conservancy do not take anti-war stances on the national level. ${ }^{39}$

In order to more effectively challenge war and militarism, we must build links between the anti-war movement and the growing movements for climate and racial justice. At the grassroots level, there is much more potential to integrate peacebuilding into the climate justice movement. For example, Extinction Rebellion, an international organization with

37 U.S. Military Is World's Biggest Polluter, “EcoWatch”, 11.11.2019, www.ecowatch.com/military-largest-polluter-2408760609.html [access: 23.01.2021].

38 C. Fournier, Reducing Global CO2 Emissions In The '20s: The Changes Needed In Energy, Transportation And Agriculture, YouMatter, 6.01.2020, youmatter.world/en/reduction-co2-emissions-targets-20s/ [access: 23.01.2021]..

39 The Nature Conservancy, The Nature Conservancy, www.nature. org/en-us/ [access: 23.01.2021]. Natural Resources Defense Council, Natural Resources Defense Council, www.nrdc.org [access: 23.01.2021], Sierra Club, Sierra Club, www.sierraclub.org [access: 23.01.2021]. 
strong youth chapters, has a Peace Group that organizes for demilitarization and climate justice. ${ }^{40}$ Similarly, groups within the racial justice movement have challenged U.S. imperialism and military domination abroad. As Robin D.G. Kelley details in the Movement for Black Lives' "A Vision for Black Lives," much of the "funds and resources needed to realize domestic demands are currently used for wars and violence destroying communities abroad." ${ }^{41}$ By realizing the connections between issues of militarism, climate injustice, and systemic racism, we can build a larger coalition of youth-led movements working for peace and social justice.

\section{Christine Odera on peace and war in Kenya}

I am a YPS practitioner who studied peace and conflict related issues at the United States International University Africa (USIU-A). My work currently centers on YPS with a focus on developing policies, programs, knowledge, best practices, and tools. Through capacity building workshops and mentoring, I work to strengthen the capacity of young people and youth-serving organizations to advance local, national, regional, and global peacebuilding strategies.

Kenya is a country in East Africa, with a population of $53,771,296$ people, median age of 20.1 years $^{42}$, and over 70 distinct ethnic groups. ${ }^{43}$ Over the last 10 years, Kenya has

40 Extinction Rebellion Peace, "Extinction Rebellion Peace", 21.01.2021, xrpeace.org/ [access: 23.01.2021].

41 R. Kelley, What Does Black Lives Matter Want?, "Boston Review”, 4.06.2020, bostonreview.net/books-ideas/robin-d-g-kelley-movementblack-lives-vision [access: 23.01.2021].

42 Worldometer, Kenya Demography 2020, 2020, www.worldometers. info/demographics/kenya-demographics/ [access: 14.03.2021].

43 East Africa living Encyclopedia, African studies center, Univer- 
made significant economic, political and social developments. In 2010, a new Constitution was approved in Kenya, giving way to a new political and economic governance system. ${ }^{44}$ The Constitution introduced a decentralized system of 47 devolved county governments, a constitutionally tenured judiciary and electoral body and a bicameral legislature. Despite these advances, Kenya still experiences increasing levels of poverty, ongoing internal and external conflicts that continue to make the economy vulnerable, and high levels of corruption and unemployment. ${ }^{45}$ Kenya's relatively youthful population (70\% of Kenya's population) is critical to economic growth, but the so-called youth bulge continues to be a challenge for the country. This is partly because of the dynamics of elite leadership across the country made up of older people and high unemployment rates. These dynamics contribute to increasing numbers of young people turning to other means to meet the high standards of living. Violence and crime are among the other means of meeting the high standard of living, which in turn affects the country's pursuit of peace.

When it comes to peace, Kenya is ranked number 125 in 2020 in the Global Peace Index (GPI), which is a decline from 122 in $2019 .{ }^{46}$ Being 125 by the GPI out of 172 independent states is a bad position and the recent decline only suggests

sity of Pennsylvania, www.africa.upenn.edu/NEH/kethnic.htm [access: 14.03.2021].

44 Kenya's new constitution brings political change, "Oxford Business Group" 2021, oxfordbusinessgroup.com/overview/moving-forward-new-constitution-has-ushered-era-political-change [access: 14.03.2021].

45 The World Bank in Kenya, "The World Bank", 31.01.2020, www. worldbank.org/en/country/kenya/overview4 [access: 14.03.2021].

46 Global Peace Index, "Vision of Humanity", 11.01.2020, www.visionofhumanity.org/maps/\#/ [access: 14.03.2021]. 
that the levels of peace in the country are getting worse. Electoral conflicts, that have been amplified by ethnic conflicts, have had a negative effect on Kenya's pursuit of peace. The need to address historical injustices since the colonial era still needs to be looked at more closely. This is because it continues to be a root cause of many local communities' marginalization and inadequate access to resources. There is also a growing need for institutional strengthening to help address these root causes - especially because the institutional failures to mitigate such injustices continue to exacerbate conflict in Kenya. These dynamics need to be addressed as a matter of urgency for the country to enjoy peace. While Kenya has experienced a lack of trust with its Independent Electoral and Boundaries Commission (IEBC) it has seen a decrease in military expenditure over the years. Notably, between 1970-2019, military expenditure as a share of Gross Domestic Product (GDP) was $1.2 \%$ in Kenya. Military spending is not among the productive activities that contribute positively to a country's GDP but it is considered a major expenditure in many countries. To spend $1.2 \%$ of the GDP is still on the high side for Kenya, considering that the expenditure could indirectly affect the economy by increasing income levels and the country is still struggling with youth unemployment.

In Africa, civil wars, misappropriation of resources, inequality and the proceeds used to undermine the justice system have long been a cause for insecurity and conflict. ${ }^{47}$ There are many factors that contribute to civil wars. Firstly, economic imbalance, especially because according to the World Bank in 2018, 40\% of Africa's population languish in poverty and cannot afford basic needs. Secondly, ethnic

47 J. Anyanwu, Economic and Political Causes of Civil war in Africa: some Econometric results. Abidjan: Africa Development bank, 2002. 
marginalization in the allocation of resources, political representation and human rights violations have been on the rise through police brutality and access to proper health care services which contribute to gender-based violence. Thirdly, the power of the government to control the country. Treaties are signed to safeguard the interests of a handful of politicians at the expense of the citizens, through trade and illegal mining of natural resources among many other issues. These issues, over the years, have been worrying, so much so that the 2020 African Union theme was on "Silencing the Guns".48

In the week of January 26th, 2021, there was blood shed among the people living in Kapedo in Turkana county in Kenya, as military troops were deployed to fight the bandits. This ongoing conflict is between different ethnic groups (Pokot and Turkanah) who are pastoralists and have, for a long time, fought over water and pasture and, more recently, over the border area that separates the two communities. ${ }^{49}$ This ongoing conflict has forced schools to close, and there is very little economic activity happening because of insecurity. Families have been displaced and are left to seek humanitarian support and pick up arms to protect themselves. This conflict is one of the barriers for building peace in Kenya and to an extent the greater Horn of Africa. Another is inter-communal violence that continues to destabilize the country. The youth play multiple roles in inter-

48 Silencing the guns is Africa Union campaign to ending all wars, civil conflicts, gender-based violence, violent conflicts and preventing genocide in the continent by 2020 .

49 N. Cheploen, Alternative conflict resolution 'could heal troubled Kapedo', "People Daily", 4.02.2020, www.pd.co.ke/news/national/alternative-conflict-resolution-could-heal-troubled-kapedo-23128 [access: 14.03.2021]. 
communal violence including both victims and perpetrators of violence as well as actors for peace. Some youth, because of unemployment, are lured in to cause belligerence and are given handouts. This does not, however, imply that a lack of income makes youth violent. Some cultural practices, like "Moranism ${ }^{50 "}$, mobilize youth to engage in violence because it is seen as pride and protecting the community.

Youth inclusion in decision making is an opportunity for peace in Kenya and Africa at large. According to Worldometer, the Median age in Africa is currently 19.7 years of age, and it is forecasted to be 24.8 years of age by 2050.Tthis number could go up but chances are it will still be within the youth bracket (15-35). Meanwhile, when Africans will be commemorating the 2030 Sustainable Development Goals, 10 years from now, the median age is anticipated to be 21.1. ${ }^{51}$ In numbers alone, it shows that African youth cannot be excluded in national building - mobilizing against anti-civil war systems, anti-military history - and therefore peacebuilding and security efforts. In this context, the exclusion of young people would be harmful not only for young people themselves but also for the communities of which they are a part.

Digital literacy is a must-have skill as a step to move us beyond war. This is not just the ability to access the internet, social media, or zoom, but also the ability to navigate safely, securely, and privately online. ${ }^{52}$ Enhancing digital literacy

50 E. Wamwitha Wandaka, Moranism, "Legal Scholar Site”, 27.01.2019, legalscholarsite.com/moranism/ [access: 21.05.2021].

51 Worldometer, Africa population, www.worldometers.info/worldpopulation/africa-population/ [access: 21.05.2021].

52 Digitally-enabled Peace and Security: Reflections for the Youth, Peace and Security Agenda, SecDev Group, November 2017, www.youth4peace.info/system/files/2018-04/2.\%20TP_Social\%20Media_SecDev.pdf [access: 21.05.2021]. 
can help the continent address some of the small arms and light weapons proliferation and make progress towards the 'Silencing the Guns' regional movement. This is because the generation of Digital IDs on the licensed gun holders, handlers and traders to track the weapons, know when it was fired and where. This will also help young people find new possibilities within cyberspace to help themselves learn about what other young people are doing to better their communities. This will also create more opportunities for employment and ensure transparency and accountability of both citizens and governments.

African youth need to reimagine value systems. They need to further their spiritual and moral development to benefit the whole of humanity. This can only be done when they oppose unfair conditions and choose peace as an unconditional commitment above all their differences. War and violence have resulted in a huge loss of life and widespread violations of human dignity. COVID19 has reminded us of the vulnerability and fragility of human existence, and that solidarity is the only way to combat the crisis that has impacted all of us. Selfishness, greed, corruption, exclusion, exploitation, ethnic profiling, inter-religious differences cause us more harm than good, and we should all take personal responsibility and not tolerate it.

Lastly, most young people are concerned about their future and worried about what comes next for them. Many responsible youths are concerned about the wake of the pandemic and urgently call on governments to help them prevent pandemics that are not yet with us but are expected to come. The challenge to leaders now is what they would like to be remembered for, if they do not help pave way for the future generation. The pandemic is showing that young 
people are not waiting to be invited. Instead, they are the first responders to the pandemic. At the heart of their response is a sense of power, resilience and a feeling that the exclusion they experience is not binding them down, but they want to be liberated from it, as they can become better public servants. This solidarity among youth is a step in the right direction - an important aspect of challenging civil wars and militarization in the continent in order to enhance the prospects for a more peaceful and socially just Africa.

\section{Alejandra Rodriguez on peace and war in Colombia}

I have been affected by war, having lived in conflict-affected parts of Colombia. I am a student of Social Communication, a member of Rotary International, a fellow of the Positive Peace Youth Workshops, and Co-chair of Rotaract for Peace, where I helped to organize the World Peace Conference in 2020. I am also a member of the WBWYN and leader of the project "Reporteritos de la Paz" (Little journalists for peace), a project of the Voces Líderes Colombia foundation.

Colombia is a South American country that has been immersed in an armed conflict for more than 50 years. This conflict is between the government and illegal armed groups such as the Revolutionary Armed Forces of Colombia (FARC) and the National Liberation Army (ELN), among others. The root causes of this conflict are many, including social inequalities, ideological differences and state neglect ${ }^{53}$, resulting in more than 400,000 direct victims to

53 J. Ríos, El Acuerdo de paz entre el Gobierno colombiano y las FARC: o cuando una paz imperfecta es mejor que una guerra perfecta, "Revista Iberoamericana de Filosofía, Política y Humanidades” 2017, No. 38. 
date. ${ }^{54}$ In October 2016, the government, headed by President Juan Manuel Santos, signed a Peace Agreement with the FARC, the oldest guerrilla group at that time and the one with the greatest territorial influence. This agreement sought to address a number of barriers to peace, including the demobilization of some 6804 FARC combatants ${ }^{55}$, a comprehensive rural reform which aimed to increase the democratic and political participation of FARC attempts to address the problems of illicit drugs, and the recognition of victims and an investigation into the truth of the conflict. All of these activities are aimed at ushering in a new era in the country, full of hope and peace. ${ }^{56}$

However, at the time of writing, some five years after signing the agreement, 246 ex-combatants and more than a thousand social leaders have been reported killed. A draft legislative act was presented to repeal the Special Jurisdiction for Peace ${ }^{57}$, suggesting that, as of March 2020, only $60 \%$ of the commitments foreseen in the Implementation Framework Plan, between 2017 and 2019, have been executed..$^{58}$

54 Centro Nacional de Memoria Histórica, Balance general del conflicto armado, Bases de datos, Observatorio de Memoria y Conflicto, micrositios.centrodememoriahistorica.gov.co/observatorio/infografias/ balance-general/ [access: 20.01.2021].

55 N. Casey, Las fallas que ponen en riesgo el acuerdo de paz en Colombia [Colombia 's Peace Deal Promised a New Era. So Why Are These Rebels Rearming?], "New York Times", 17.05.2019.

56 J. Ríos, El Acuerdo de paz entre el Gobierno colombiano y las FARC: o cuando una paz imperfecta es mejor que una guerra perfecta, "Revista Iberoamericana de Filosofía, Política y Humanidades" 2017, No 38.

57 La paz de Colombia, cuatro años después de la firma del acuerdo, "El Heraldo", 24.11.2020.

58 Procuraduría General de la Nación, Procuraduría alertó sobre la forma desarticulada en la que se avanza en la implementación del Acuerdo de Paz, www.procuraduria.gov.co/portal/Procuraduria-aler- 
These dynamics have contributed to uneasiness and uncertainty regarding the current situation in the country.

As such, despite the Peace Agreement, Colombia is currently ranked 140 out of 163 countries according to the Global Peace Index, which is a report produced by the Institute for Economics and Peace (IEP) $)^{59}$ that measures the relative position of nations' and regions' peacefulness. This finding, among other things, suggests that the intended progress on the peace agreement has not been made. Other examples include the lack of protection for social leaders, former combatants and victims of the Comprehensive National Program for the Substitution of Illicitly Used Crops. These factors have been aggravated by the present pandemic. $^{60}$

Social inequality and corruption have been determining factors in the development of the armed conflict. These dynamics have perpetuated a scenario where war is considered a business, and politics a constant promise to "save the country." Neither one has offered positive results. To this end, research suggests that Colombia is the nation with the greatest inequalities among its territories ${ }^{61}$ As a partial result, it can be argued that Colombia's socioeconomic and cultural dynamics can be defined by the culture of violence that exists in the country. By this I mean a form of violence

to-sobre-la-forma-desarticulada-en-la-que-se-avanza-en-la-implementacion-del-Acuerdo-de-Paz-.news [access: 20.01.2021].

59 Institute for Economics \& Peace, Global Peace Index 2020: Measuring Peace in a Complex World, Sydney, June 2020. Available from: http://visionofhumanity.org/reports [access: 20.05.2021].

60 R. Grasa, Colombia cuatro años después de los acuerdos de paz: un análisis prospectivo, Fundación Carolina 2020.

61 Forbes Staff, Colombia es el país más desigual de toda América Latina, "Forbes Colombia”, 30.10.2020. 
that goes beyond the physical and governmental, as it is perpetrated by society itself, thus minimizing empathy towards the pain of others and assuming barbarity as a daily occurrence. ${ }^{62}$ Still, it is precisely from this point that we as young people must detach ourselves to pursue a different vision of the world and work towards a culture of peace. ${ }^{63}$

Against this backdrop, although it may seem discouraging to work towards peace in Colombia, it should be noted that the peace agreements led to, among other things, the creation of a truth commission and a special jurisdiction, which work to uncover a more historical and nuanced understanding of the conflict, comprehensively support the victims, and ensure the non-repetition of destructive events of the past. ${ }^{64}$ This is important because it means that after all these years, the armed conflict becomes an important part of the public agenda. This can in turn help to better educate and mobilize people across the country to act to change the social injustices in Colombia through direct political participation or the development of peacebuilding projects at all levels of society, from formal peace processes to grassroots, local-level work.

A notable example of this is the work of the Voces Líderes Colombia foundation, which has implemented highimpact projects in different parts of the country. One of

62 R. Grasa, Colombia cuatro años después de los acuerdos de paz: un análisis prospectivo, Fundación Carolina 2020.

63 P. Gittins, The Role of Youth in Peace and Security, [in:] idem, A Global Security System: An Alternative to War, $5^{\text {th }}$ ed. World BEYOND War, 2020.

64 J. Ríos, El Acuerdo de paz entre el Gobierno colombiano y las FARC: o cuando una paz imperfecta es mejor que una guerra perfecta, "Revista Iberoamericana de Filosofía, Política y Humanidades" 2017, No. 38. 
these is "Reporteritos", a project focused on children between 5 and 14 years old, which seeks to develop communication skills in children so that they can exercise leadership roles in their communities and also, through play, learn about issues of cultural heritage, peace, values, and the history of the country. Another example is the work done by Rotary International in Colombia. In 2019, for example, a project called "Positive Peace Workshops for Youth in Colombia" trained more than 200 young people from Rotaract and the Young Men's Christian Association (YMCA), both being volunteer organizations in the development of projects focused on peacebuilding. The result was some 52 positive peace projects led by young people across the country. ${ }^{65}$

All of the above leads us to conclude that after so many years of violence, one of the greatest tools to overcome the culture of violence and create a culture of peace has been comprehensive education for all sectors of society, since it acts as a tool for social change with which lasting peace can be achieved. ${ }^{66}$ On this, when we talk about the opportunity for all young people in Colombia to have access to free and quality education, we are talking about a transformative approach, one where the full and meaningful participation of young people in peace and security research and programming is realized and where the capacity building opportunities (including training around political leadership and citizen participation for young people, as well as the opportunities for youth employment, are dramatically improved.

65 Youth Positive Peace workshops launch in Colombia, Vision of $\mathrm{Hu}-$ manity, available from: www.visionofhumanity.org/youth-positive-peaceworkshops-launch-colombia/ [access: 20.01.2021].

66 Sotelo Amaya, J.D., I.C. Castellanos Londoño, y R. Rodríguez Andrade, La paz: una oportunidad de desarrollo social, "Revista de la Universidad de La Salle” 2017, No. 73. 
To work towards this goal, sufficient investment in contextualized and flexible models of educational training and constant accompaniment by the State is needed. ${ }^{67}$ Within this context, and with regards to the peace agreement, the full participation of youth as agents and leaders for peace in decision-making and action processes is needed to deliver on the aims of the peace process.

\section{Daria Pakhomova on peace and war in Russia}

I am from the Russian Federation and currently studying for my bachelor's degree in International Relations at Collegium Civitas in Warsaw, Poland. My interest in peace began more formally during my thesis which looked at the impact of the UN peace operations. This interest has intensified since joining the WBWYN.

There are many barriers in Russia which prevent the country from building a sustainable peace. One of them is the fact that Russia tends to take one of the leading positions in the global military domain. In 2020, Russia's military expenditure was estimated at around $\$ 61$ billion. Consequently, the state was ranked as one of the fifteen most militaristic countries represented by the Stockholm International Peace Research Institute (SIPRI) ${ }^{68}$. In an analysis of military strength, Russia is ranked 2 of out of the 140 coun-

67 En Colombia la paz es jóven, Programa de las Naciones Unidas para el Desarrollo [United Nations Development Program], www.co.undp.org/content/colombia/es/home/presscenter/articles/2017/03/14/encolombia-la-paz-es-joven.html [access: 20.05.2021].

68 D. Lopes Da Silva, N. Tian, A. Marksteiner, Trends in World Military Expenditure, 2020, Stockholm International Peace Research Institute, 2021, sipri.org/sites/default/files/2021-04/fs_2104_milex_0.pdf [access: 20.05.2021]. 
tries. According to this work, Russia has 1,014,000 military personnel serving full-time and 2,000,000 of reserve military personnel. ${ }^{69}$

It is noteworthy that a military career is very popular among the young people in Russia. According to one of the major Russian Public Opinion Research Centers, service in the military is one of the most highly regarded professions by Russian youth. ${ }^{70}$ Many young males across the country prefer studying at the military academies rather than civilian universities for pragmatic reasons. ${ }^{71}$ The tuition fees are mainly covered by the state, cadets are usually accommodated, clothed and fed at governmental expenses, and employment in the military is always guaranteed.

Because power in Russia has remained centralized for more than twenty years, it has been challenging to meaningfully engage young dissidents in politics. The strongest and most suppressive party called the "United Russia" is powerful, always being allocated a significant majority of the seats in the various levels of the governmental bodies. A rare youth initiative, called "Young Guard of United Russia" is only available to individuals who share the state's vision. Also, the Russian government has established the militarypatriotic youth movement "Yunarmiya" ("the Young army") to train kids aged from 8 to 18 to honor war. ${ }^{72}$ In hopes of

69 Reserve Military Manpower (2021), "Global Firepower” 2021, www.globalfirepower.com/active-reserve-military-manpower.php? [access: 20.05.2021].

70 Kids and professions, "Levada Center", 26.06.2017, www.levada.ru/ en/2017/09/26/kids-and-professions/ [access: 20.05.2021].

71 D. Vorotnikov, Demand for Places at Military Universities Doubles, University World News, 7.09.2019, www.universityworldnews.com/ post.php?story=201909051551435 [access: 20.05.2021].

72 I. Sharafiyev, Making real men out of schoolchildren. Meet the 
raising future generations of true adherents, the state dresses children in military uniforms, and teaches them how to shoot and march in parade formation. In regard to the parades, it is impossible not to mention the famous Moscow Victory Day Parade. This is an important military event held annually on May $9^{\text {th }}$ in Russia. The parade is accompanied by innumerable military equipment, ranging from tanks to ballistic missiles. To some, this parade is perceived as a demonstration of Russia's military capacity to others. Moreover, during the parade in 2021, the Russia President highlighted that the state is always ready to defend its interests. ${ }^{73}$

Moving from a discussion of war and militarism to peace, Russia is considered to be one of the least peaceful states. According to the Global Peace Index, Russia is settled near the bottom in terms of negative peace. The Institute for Economics and Peace places Russia $154^{\text {th }}$ out of 163 countries. ${ }^{74}$ Thus, Russia does quite badly for a modern state located in Europe.

To summarize the aforementioned, Russia's militaryoriented government and its patriotic war-prone ideology undercuts the prospects for peace in the country. The Russian government, as well as its current ideological approach, must be changed in order to push the state towards peace

'YouthArmy', Russia's new hope for military-patriotic education, "Meduza", 6.10.2017, https://meduza.io/en/feature/2017/10/06/making-real-menout-of-schoolchildren [access: 20.05.2021].

73 I. Khurshudyan, At Russia's Victory Day parade, a show of military might amid tensions with the West, "The Washington Post", 9.05.2021, www.washingtonpost.com/photography/interactive/2021/russia-paradevictory-day-putin/ [access: 20.05.2021].

74 Institute for Economics \& Peace. Global Peace Index 2020: Measuring Peace in a Complex World, Sydney 2020, https://www.visionofhumanity.org/wp-content/uploads/2020/10/GPI_2020_web.pdf [access: 20.05.2021]. 
and social justice. The state needs a progressive (young) leader, someone who upholds democratic values and the ideals of sustainable development.

Another important mechanism for moving us toward a world beyond war is peacekeeping. ${ }^{75}$ In this regard, it is interesting to note that Russia used to mediate international disputes. One example is the past Yemeni crisis. ${ }^{76}$ While such work might not be considered a 'successful mediation,' engaging in this work might provide suitable career opportunities for those in Russia who want to develop themselves in the peace arena. Another example is the current peace operation taking place in Nagorno-Karabakh. The soldiers sent there compose the only peace squad launched in Russia. This is the same peace squad that participated in the war with Georgia. ${ }^{77}$ This raises the question: are these soldiers working for peace or war? With this in mind, it is extremely important to shift the focus to a nonviolent peacekeeping and a proper mediation. Such initiatives, coupled with a range of non-violent security measures, can help to advance the prospects for peace in the country.

Another important step that can be taken towards peace in Russia is to demilitarize security ${ }^{78}$, which includes pro-

75 D.G. Levis, Russia as Peacebuilder? Russia's Coercive Mediation Strategy, The George C. Marshall European Center for Security Studies, June 2020, www.marshallcenter.org/en/publications/security-insights/ russia-peacebuilder-russias-coercive-mediation-strategy-0 [access: 20.05.2021].

76 Russia's Mediating Role in Southern Yemen, "Carnegie Endowment for International Peace”, 12.10.2018, carnegieendowment.org/ sada/77482?utm_source=rss\&utm_medium=rss [access: 20.05.2021].

77 D. Dmitriev, Here's what Russia has pledged (and risked) with peacekeepers in Nagorno-Karabakh, "Meduza", 11.11.2020, meduza.io/ en/cards/1-960 [access: 20.05.2021].

78 P. Gittins, The Role of Youth in Peace and Security. 2020, [in:] 
cesses of disarmament. This requires the support of global institutions which would carefully exercise control over the states' weaponry. In this regard, Russia supposedly commenced the eradication campaign of chemical weapons in 2014 in accordance with the Chemical Weapon Convention. Evidence suggests that Russia destroyed all its chemical weapons in 2017. ${ }^{79}$ However, Alexey Navalny was poisoned by the chemical "Novichok" in 2020, according to many foreign agents. The Organization for the Prohibition of Chemical Weapons in France was among those which reaffirmed the fact of chemical exposure. ${ }^{80}$

This case proves the lack of effective sources of control over weaponry in Russia, which, in turn, represents another obstacle for peace in the country. The violation of human rights and international law is another obstacle for lasting peace. A further dynamic that needs to be addressed if Russia is to move more toward peace is to establish gender equality and eliminate discrimination against minorities. The good news is that social movements across the country are working to raise awareness of these issues and mobilize more people to work for peace.

In summary, some of the steps needed to move Russia more towards a just and sustainable peace include demilitarization, authentic peacekeeping operations, and the

A Global Security System: An Alternative to War, ed. P. Gittins, $5^{\text {th }}$ ed. World BEYOND War, 2020.

79 The Chemical Weapons Convention (CWC) at a Glance, Arms Control Association, www.armscontrol.org/factsheets/cwcglance [access: 20.05.2021].

80 Macron urges Putin to shed light on 'attempted murder' of opponent Navalny, "France 24", 14.08.2020, www.france24.com/en/20200914french-swedish-labs-confirm-navalny-poisoned-with-novichok [access: 20.05.2021]. 
promotion of non-violent approaches to opposing war and increasing tolerance, nationally and globally.

\section{Laiba Khan on peace and war in India}

I am currently pursuing a bachelor's degree in Business Administration. I am a member of the WBWYN, Rotaract, and believe in developing new knowledge to stay ahead of the trending curves around peace and social change. I help to organize peace awareness events to educate youth in her country and beyond. I believe that "Slavery is one of the worst forms of violence - as is the denial of education. Education is key to liberating children from slavery" (Kailash Satyarthi). ${ }^{81}$

India is a diverse country with 1.3 billion people, and has become the second-most populous country on the planet. Today, India has 447 native languages and a GDP of 2.86 trillion (US\$), making the country the fifth-largest economy in the world. India is considered one of the fast-growing economies in the world because of the unprecedented hike in its economic growth from $\$ 468$ billion in 2000 to $\$ 2.10$ trillion in $2015 .{ }^{82}$ India is also known for its rich variety of food, places, and culture.

Concerning peace and war, while India climbed two spots to become number 139 on the Global Peace Index in $2020^{83}$, its military spending grew by 6.8 percent to $\$ 71.1$ billion in

8110 Inspiration Quotes on Education. https://borgenproject.org/ inspirational-quotes-on-education/ [access: 20.05.2021].

82 The World Bank in India, The World Bank, www.worldbank.org/ en/country/india/overview [access: 20.05.2021].

83 India Climbs Two Ranks to $129^{\text {th }}$ Position on IEPS Global Peace Index, Deccan Herald, www.deccanherald.com/national/world-peaceday-india-climbs-two-ranks-to-139th-position-on-ieps-global-peaceindex-890882.html [access: 20.05.2021]. 
the year $2019 .^{84}$ India's inequality-adjusted human development position dropped by one position to 130, losing nearly half the progress made in the past 30 years. ${ }^{85}$ Moreover, India's rank has slipped six places to $86^{\text {th }}$ among 180 countries in the Corruption Perception Index (CPI) in $2020 .^{86}$

The financial disparity in India is extreme, and getting worse every year. This means the rich are getting richer and the poor are not catching up. This has led to an increase in underdeveloped areas and the people living in them. Near my small home town of Mhow, there is a slum where hundreds of poor people live on the streets. Most people who are living on the streets are malnourished, illiterate, jobless, prone to alcoholism, and do not have access to proper sanitation. Due to this type of financial disparity, children and women are forced to do labor or household work at lower wages. There are thousands of similar slums in India. According to the UN Millennium Development Goals (MDG) program, 8 million people out of 1.2 billion Indians, roughly equal to $6.7 \%$ of India's population, lived below the poverty line of $\$ 1.25$ per day in 2018-2019. ${ }^{87}$

84 S. Gurung, India third largest military spender in world, after US and China, 27.04.2020, economictimes.indiatimes.com/news/defence/ global-military-spending-saw-largest-increase-in-decade-in-2019-china-india-in-top-3-study/articleshow/75404166.cms?from $=\mathrm{mdr}$ [access: 20.05.2021].

85 J. Chandra, India up one rank in UN development index, "The Hindu", 10.12.2019, www.thehindu.com/news/national/india-up-onerank-in-un-development-index/article30259959.ece.

86 India's rank slips to 86th in corruption perception index 2020, "The Economic Times", 28.01.2021, economictimes.indiatimes.com/news/ economy/indicators/indias-rank-slips-to-86th-in-corruption-perceptionindex-2020/articleshow/80512814.cms [access: 20.05.2021].

87 Poverty in India, Wikipedia, en.wikipedia.org/wiki/Poverty_in_ India\#: :text=Based\%20on\%202019's\%20PPPs\%20International,of\%20 \%241.25\%20in\%202018\%E2\%80\%9319 [access: 20.05.2021]. 
Despite these alarming statistics, there are many opportunities for building peace in India. For the purposes of this chapter, three are outlined here. The first is education. Education can be a foundation for eradicating poverty and fostering healthy living in India. ${ }^{88}$ An analytical study from 1990 estimated that it would take until 2060 for India to achieve universal literacy at the then current rate of progress. ${ }^{89}$ The more it will take to achieve one hundred percent literacy, the worse conditions may become. If people have adequate education, they can make choices and earn a living for themselves. Hence, education is an effective way of combating poverty, one of the prevalent peacebuilding barriers.

The second opportunity is ending bribery. The Corruptions Perceptions Index, 2019 report, currently ranks 180 countries on a scale from 100 (very clean) to 0 (highly corrupt). On the list, India ranks $80^{\text {th }}$ with a score of 41 , which is perceived as highly corrupt. As an example, if a rich person is stuck in a legal case or any sort of trouble, they can easily get free of the charges simply by bribery of corrupt politicians. It is not the same with the underprivileged people since they have nothing with which to bribe. This not only generates psychological frustration to the underprivileged but also reduces productivity growth, investment, and job opportunities for poor people.

The third opportunity is to decrease military spending. India is the world's third largest military spender, after the U.S.

88 M.B.I. Omoniyi, The role of education in poverty alleviation and Economic development: a theoretical perspective, British Journal of Arts and Social Sciences, 2013, ucanapplym.s3.ap-south-1.amazonaws.com/ RGU/notifications/Syllabus/UG\%20HONS\%20CBCS/EDUCATION.pdf [access: 20.05.2021].

89 How Female Literacy Affects Fertility: The Case of India, Population Institute, East-West Centre, December 1990, www.eastwestcenter. org/fileadmin/stored/pdfs/p\&p015.pdf [access: 20.05.2021]. 
and China. India's military spending grew $6.8 \%$ to $\$ 71.1$ billion, outpacing Japan ( $\$ 47.6$ billion) and South Korea ( $\$ 43.9$ billion). ${ }^{90}$ It's overall defense spending has witnessed an average growth rate of $9 \%$ in the last 10 years. ${ }^{91}$ This increase is mainly due to the political tension with Pakistan \& China.

Amidst these opportunities and barriers for building peace, we find that the definition of peacebuilding itself surfaces. Peace is not just limited to ending wars and resolving conflicts between countries. It is also about addressing local, national, and global issues rooted in poverty, corruption, inequality, and racial biases, which ultimately result in an unbalanced state of peace.

To advance peace, first, we must encourage youth to participate in activities focused on education and healthy living. Rotaract clubs, a youth led organization whose motto is "fellowship through service" is one of the best ways to do this. Second, there is a need for building strategic programs for upskilling locals. One World Education, is a great example of a nonprofit organization working collaboratively with a public school district to achieve wonderful results for students. "The essay competition at the Martin Luther King Library was the culmination of an intensive two-month training program that involved all 2,300 high school seniors in the D.C. school system. The students were coached and led through exercises designed to improve their writing and

90 E. Roche, India is world's 3rd largest military spender, expense rose by $6.8 \%$ in 2019, Mint, 28.04.2020, www.livemint.com/news/india/indianamong-top-three-military-spenders-in-2019-sipri-11587957496033.html [access: 20.05.2021].

91 A. Bhatnagar, India's defence spending in 7 charts, "The Times of India”, 30.01.2021, timesofindia.indiatimes.com/india/indias-defencespending-in-7-charts/articleshow/80600625.cms [access: 20.05.2021]. 
research skills."92 Programs like these can contribute to uplifting society as a whole. To paraphrase an old proverb Let's start small, to achieve big!

\section{Discussion}

The above accounts are written in very different ways and illustrate the diversity in young people's thoughts and experiences of peace and war in five different contexts. Yet, while each reflection is unique, there are common themes. These include the importance of peace education (from primary school to community activities), reducing military spending, improving the meaningful participation of youth in such activities, reconstructing social infrastructures to shift toward preferences for non-violent conflict, peacekeeping operations to replace wars, deglorifying the military, reducing military access and marketing to youth, and focusing attention on bottom-up peace activities that include work at the community, local, and national levels. Because young people are disproportionately affected by the aforementioned issues, it is necessary, and their human right, that they should play an active role in addressing these common themes.

\section{Concluding remarks}

This chapter has provided a set of personal reflections on peace and war from the U.S., Kenya, Colombia, Russia, and India, written by young people in their own words. It made

92 Q. Wodon, Need a great education project for your club?, "Rotary Voices”, 12.01.2016, blog.rotary.org/2016/01/12/need-a-great-educationproject-for-your-club/ [access: 20.05.2021]. 
the point that all voices matter in the global discourse on peace and war, and demonstrates young people's capacity for speaking for themselves on issues that matter to them. Through doing so, we hope to have persuaded you of the importance of youth producing their own narratives of peace and war and that, with the right tools and support, it is possible to speak about youth as knowledge creators, unlike much of the contemporary peace work that speaks about youth as knowledge recipients.

To put it simply, we should not only rely on the writings of adults that identify themselves as spokespeople for young people. We should also seek to produce work that draws on the first-hand accounts and lived experience of young people that is written with or by them, for everyone. This chapter therefore becomes our contribution to such debates, in the hope that this sharing can add to the knowledge-base of peace and war studies and influence other young people to generate their accounts that seek to center youth perspectives and ideas related to peace and war. We would like to finish this chapter, therefore, with an invitation for more young people to produce their accounts of peace, war, and related issues, and we hope to be reading these texts soon.

\section{Bibliography}

Anyanwu J., Economic and Political Causes of Civil war in Africa: some Econometric results, Abidjan: Africa Development Bank, 2002.

Auteserre S. The frontlines of peace: An insider's guide to changing the world, Oxford 2021, www.visionofhumanity.org/wp-content/uploads/2021/01/EVP-2021-web-1. pdf. 
Bhatnagar A., India's defence spending in 7 charts, "The Times of India", 30.01.2021, timesofindia.indiatimes. com/india/indias-defence-spending-in-7-charts/articleshow/80600625.cms.

Bouzar K., No Peace, No Sustainable Development: A Vicious Cycle that We Can Break, United Nations Chronicle, www.un.org/en/chronicle/article/no-peace-no-sustainable-development-vicious-cycle-we-can-break.

Casey N., Las fallas que ponen en riesgo el acuerdo de paz en Colombia [Colombia 's Peace Deal Promised a New Era. So Why Are These Rebels Rearming?], "New York Times".

Centro Nacional de Memoria Histórica, Balance general del conflicto armado, Bases de datos, Observatorio de Memoria y Conflicto, micrositios.centrodememoriahistorica.gov.co/observatorio/infografias/balance-general/ Chandra J., India up one rank in UN development index, "The Hindu", 10.12.2019, www.thehindu.com/news/national/india-up-one-rank-in-un-development-index/article30259959.ece.

Cheploen N., Alternative conflict resolution 'could heal troubled Kapedo', "People Daily", 4.02.2020, www.pd.co. $\mathrm{ke} /$ news/national/alternative-conflict-resolution-couldheal-troubled-kapedo-23128.

Conner C., Bohan C., The Second World War's impact on the progressive educational movement: Assessing its role, Middle and Secondary Education Faculty Publications, 2014, scholarworks.gsu.edu/mse_facpub/74.

Corcione A., Why Poor Youth Are Targeted for Military Recruitment, "Teen Vogue", 22.01.2019, www.teenvogue. com/story/the-military-targets-youth-for-recruitment. Crawford N., Pentagon Fuel Use, Climate Change, and the 
Costs of War, "Costs of War Project", 13.11.2019, https:// watson.brown.edu/costsofwar/files/cow/imce/papers/2019/Summary_Pentagon\%20Fuel\%20Use\%2C\%20 Climate\%20Change\%2C\%20and\%20the\%20Costs\%20 of\%20War\%20(1).pdf.

Dennen V., On war: Concepts, definitions, research data: A short literature review and bibliography, 2005.

Dmitriev D. , Here's what Russia has pledged (and risked) with peacekeepers in Nagorno-Karabakh, Meduza, 11 Nov. 2020, meduza.io/en/cards/1-960.

Engler M., Anti-War Movements, From Vietnam to Today, Morningside Center for Teaching Social Responsibility, 1.04.2017, www.morningsidecenter.org/teachable-moment/lessons/anti-war-movements-vietnam-today.

Foucault M., Fearless speech, Los Angeles Semiotext(e) 2001. Fournier C., Reducing Global CO2 Emissions In The '20s: The Changes Needed In Energy, Transportation and Agriculture, YouMatter, 6.01.2020, youmatter.world/en/ reduction-co2-emissions-targets-20s/.

Gittins P., Introduction, 2016. In Gittins and Velázquez-Castellanos, Peace and Conflict in Bolivia, Konrad Adenauer Foundation, 2016.

Gittins, P. Peace and peace education, 2016. In Gittins and Velázquez-Castellanos. Peace and conflict in Bolivia, Konrad Adenauer Foundation, Bolivia, 2016.

Gittins P. The role of youth in peace and security. In Gittins P. (ed.) A global security system: An alternative to war. $5^{\text {th }}$ ed. World BEYOND War, Charlottesville, 2020. Gittins P. (ed.) A global security system: An alternative to war, $5^{\text {th }}$ ed. World BEYOND War, Charlottesville 2020. Gittins and Velázquez-Castellanos, Peace and conflict in Bolivia, Konrad Adenauer Foundation, Bolivia 2016. 
Grasa R., Colombia cuatro años después de los acuerdos de paz: un análisis prospectivo, Fundación Carolina 2020.

Gurung S., India third largest military spender in world, after US and China, 27.04.2020.

Hjelmgaard, K., A Reckoning Is Near: America Has a Vast Overseas Military Empire. Does It Still Need It?, U.S. Today, Gannett Satellite Information Network, 25.02.2021, www.U.S.today.com/in-depth/news/world/2021/02/25/ us-military-budget-what-can-global-bases-do-vs-covidcyber-attacks/6419013002/.

IEP (Institute for Economics and Peace), Global Peace Index, 2016, New York: IEP.

IEP (Institute for Economics and Peace), Global Peace Index 2020: Measuring Peace in a Complex World, Sydney, June 2020. Available from: http://visionofhumanity.org/ reports.

IEP (Institute for Economics and Peace). Global Peace Index 2020: Measuring Peace in a Complex World, Sydney, 2020 Available from: https://www.visionofhumanity.org/ wp-content/uploads/2020/10/GPI_2020_web.pdf.

Kelley R., What Does Black Lives Matter Want? Boston Review, 4.07.2020, bostonreview.net/books-ideas/robin-dg-kelley-movement-black-lives-vision.

Khurshudyan I., At Russia's Victory Day parade, a show of military might amid tensions with the West, "The Washington Post", 9.05.2021, www.washingtonpost.com/photography/interactive/2021/russia-parade-victory-dayputin/.

Lakhani N., Who Killed Berta Cáceres?: Dams, Death Squads, and an Indigenous Defender's Battle for the Planet, Verso Books, 2020.

Levis D.G., Russia as Peacebuilder? Russia’s Coercive Media- 
tion Strategy, The George C. Marshall European Center for Security Studies, June 2020, www.marshallcenter.org/ en/publications/security-insights/russia-peacebuilderrussias-coercive-mediation-strategy-0.

Loewen J., Lies My Teacher Told Me: Everything Your American History Textbook Got Wrong, "The New Press” 2019. Lopes Cardozo M.L.J., Higgins S., Le Mat M.L.J., Youth agency and peacebuilding: an analysis of the role of formal and non-formal education Synthesis report on findings from Myanmar, Pakistan, South Africa and Uganda, Research Consortium Education and Peacebuilding, Amsterdam 2015.

Lopes Da Silva D., Tian N., Marksteiner A., Trends in World Military Expenditure, 2020, Stockholm International Peace Research Institute, 2021, sipri.org/sites/default/ files/2021-04/fs_2104_milex_0.pdf.

Lotta T., Wallensteen, Armed conflict, 1946-2012, "Journal of Peace Research" 2013. Vol. 50 (4).

Martin S.B., Burbach J.H., Benitez L.L., Ramiz I., Participatory action research and co-researching as a tool for situating youth knowledge at the centre of research, "London Review of Education" 2019, Vol. 17 (3).

McNiff J., Writing and doing action research, London 2014. Neimark B., Belcher O., Bigger P., The US military is a bigger polluter than more than 100 countries combined, Quartz, 28.07.2019, qz.com/1655268/us-military-is-a-bigger-polluter-than-140-countries-combined/.

Office of People Analytics, Propensity Update, 2017, jamrs. defense.gov/Portals/20/Futures-Survey-Spring-2017.pdf. Omoniyi M.B.I., The role of education in poverty alleviation and Economic development: a theoretical perspective, "British Journal of Arts and Social Sciences" 2013, 
ucanapplym.s3.ap-south-1.amazonaws.com/RGU/notifications/Syllabus/UG\%20HONS\%20CBCS/EDUCATION.pdf.

Ríos J., El Acuerdo de paz entre el Gobierno colombiano y las FARC: o cuando una paz imperfecta es mejor que una guerra perfecta, "Revista Iberoamericana de Filosof ía, Política y Humanidades" 2017, No. 38.

Roche E., India is world's 3rd largest military spender, Mint, 28.04.2020, www.livemint.com/news/india/indian-among-top-three-military-spenders-in-2019-sipri-11587957496033.html.

Said E., Orientalism, London 1995.

Shah S., The US Has Been at War 225 out of 243 Years since 1776, "The News International”, 9.01.2020, www. thenews.com.pk/print/595752-the-us-has-been-at-war225-out-of-243-years-since-1776.

Sharafiyev, I. Making real men out of schoolchildren. Meet the 'YouthArmy', Russia's new hope for military-patriotic education, "Meduza", 6.10.2017, https://meduza.io/en/ feature/2017/10/06/making-real-men-out-of-schoolchildren.

Simpson G., The missing peace: Independent progress study on youth, peace and security, 2018, www.youth4peace. info/UNSCR2250/Introduction.

Smithberger M. and Hartung W., Making sense of the \$1.25 trillion national security state budget, Project on Government Oversight, 7.05.2019, pogo.org/analysis/2019/05/ making-sense-of-the-1-25-trillion-national-securitystate-budget/.

Sotelo Amaya J.D., I.C. Castellanos Londoño, y R. Rodríguez Andrade, La paz: una oportunidad de desarrollo social, "Revista de la Universidad de La Salle" 2017, No 73, 2017. 
United Nations, World youth report 2018: Youth and the 2030 agenda for sustainable development, United Nations, 2019, New York, doi:10.18356/0c6f53e0-en. Vorotnikov E., Demand for Places at Military Universities Doubles, "University World News", 7.09.2019, www.universityworldnews.com/post.php?story $=20190905155$ 1435.

Wodon Q., Need a great education project for your club?, "Rotary Voices", 12.01.2016, blog.rotary.org/2016/01/12/ need-a-great-education-project-for-your-club/.

World Bank, The World Bank in India, The World Bank, www.worldbank.org/en/country/india/overview.

World Bank, The World Bank in Kenya, The World Bank, 31.07.2020, www.worldbank.org/en/country/kenya/overview.

World Health Organization Geneva. World Report on Violence and Health, 2002, www.who.int/violence_injury_ prevention/violence/world_report/en/abstract_en.pdf.

\begin{abstract}
Most texts about peace, war, and youth are written by adults; whereas the purpose of this chapter is for young people to produce their own reflections on their experience of peace and war. Using the words and ideas of young people, the chapter offers personal reflections on peace and war from the U.S., Kenya, Colombia, Russia, and India. The analysis centers on the main opportunities and barriers for building peace in the said contexts and what steps might be taken to move us toward a world beyond war. This chapter emerges from a collaborative venture with young people from different parts of the world as part of a larger youth-led, intergenerational, initiative led by World BEYOND War. The point of departure for the ideas in this chapter is that all voices matter in the global discourse on warto-peace transitions, and that more attention needs to be given to
\end{abstract}


supporting young people to produce their own accounts of peace, war, and related issues.

Keywords: Peace and Conflict Studies, War Studies, Security Studies, Youth Studies, Youth 


\author{
Anna Adamus-Matuszyńska \\ University of Economics in Katowice \\ ORCID ID: https://orcid.org/0000-0003-3234-4599
}

\title{
A new perspective on conflict resolution. Does the concept of conflict resolution help to resolve disputes in Asian countries?
}

\section{Introduction}

Conflict is a ubiquitous phenomenon. Hence, each society develops its own norms, rules, laws, and institutionalized forms leading to its resolution. Legal regulations determine the resolution of disputes both on a micro and macro scale.

The conflict has its dynamics and stages, in which its resolution plays a significant role. Ending the conflict means stopping action against the other party. Solving the conflict means revealing the causes of a given situation and choosing one of the many alternative options to organize the relations between the parties of the conflict situation. Ending a conflict does not always mean resolving it. For example, Wright believes that a conflict is resolved if there is definitive acceptance of a decision by all parties involved. During wars when physical forces are used, complete acceptance of the end of the conflict may be ruthless, but in situations of conflicts of ideas, politics and demands, words such as 'definitive solution' or 'acceptance of the explanation' are relative. The end of the conflict may be understood differently by both par- 
ties $^{1}$. There might be more than the traditional two parties involved in the conflict, its ending may be perceived differently by each of the parties, as in the case of the 2003 war in Iraq, which was announced by the United States, while neither the Iraqis themselves, nor the international community recognised that announcement as the end of hostilities.

The analysis of the conflict dynamics reveals that the parties have three paths at their disposal: the escalation of the conflict, the search for a way to solve it, or the disconnection of the relationship. There have been many approaches to methods of conflict solving. In the literature, one may find some terms which show various methods of ending the conflict. A settlement which is an agreement on the issue that ends an extant conflict ${ }^{2}$. A resolution is an agreement in which most of all issues "are cleared up"3. As Fischer states Conflict resolution refers to both the process of addressing difficult conflicts and the outcomes of the process, which must be mutually acceptable and beneficial and are self-sustaining and adjustable to changing conditions. As such, conflict resolution deals with both the objective issues in the dispute and the subjective or human elements in minds and in the relationship of the parties ${ }^{4}$.

Conflict resolution is regulated by law and social norms in democratic countries. An election campaign, which is

1 Q. Wright (1990), The Nature of Conflict, Conflict, [in:] Readings in Management and Resolution, eds. J. Burton, F. Dukesa, London, p. 28.

2 P.J. Carnevale, Creativity in the Outcomes of Conflict, [in:] The Handbook of Conflict Resolution. Theory and Practice, eds. M. Deutsch, P.T. Coleman, E.C. Marcus, San Francisco 2006, pp. 414-435.

3 Ibidem, p. 417.

4 R.J. Fisher, International Encyclopedia of the Social \& Behavioral Sciences (Second Edition), 2015. 
in fact a kind of conflict situation, ends with the victory of one political party, and the others accept the result, because they know that they will have the opportunity to win in the next elections. In totalitarian countries and dictatorships, free and rivalry elections are replaced by the suppression of views different from those in power. Ending a conflict means forcing to surrender, to accept a manipulated election result.

Observations of contemporary societies led the Norwegian researcher Johan Galtung to the concept of conflict resolution, which he describes using three RRR - resolution, reconstruction and reconciliation ${ }^{5}$. The method of conflict resolution is its essence, each conflict must be resolved in some way. The reconstruction occurs when violence has arisen. Galtung emphasizes that in every conflict there is violence, however, it can take various forms: open and hidden. Reconstruction is a complex process that consists of such phenomena as:

1) rehabilitation when people were injured;

2) reconstruction when material goods have been damaged;

3) restructuring when the social structure has been destroyed;

4) rebuilding the culture after it has been destroyed.

Reconciliation is a prerequisite for completing the conflict resolution process. It will fulfill its function, that is, it will recreate partnership relations between the opposing parties only when they cooperate in reaching an agreement and rebuilding mutual relations. There must be close links between the three elements of the conflict management strategy. Solving, reconstructing, and reconciling are equal

5 J. Galtung, Violence, War and the Aftermath: On Visible and invisible consequences of violence and what to do about Them (typscript), 1996. 
components of one diachronic process, therefore it is necessary to undertake them simultaneously.

According to the authors of "Social Conflict", parties involved in a conflict situation use one of the three strategies ${ }^{6}$ :

1. contending by attempting to impose a party's preferred solution, this is a method in which a party takes into account only its own interests and tries to persuade or force its will by making the opponent to surrender;

2. yielding, which involves lowering party's aspirations, agreeing to reach less than the party would like;

3. problem solving is the strategy when the parties make efforts to identify the issues dividing them and search for a solution that will satisfy both.

Conflicting parties choose one of the strategies, which results in resignation from choosing another. The three strategies are mutually exclusive, that is, if one party gives up, it cannot simultaneously seek a solution that satisfies both parties. The authors develop the dual concern model, which considers Party's own outcomes and Other's outcomes, which, in addition to the three strategies mentioned, also includes avoiding as a method to prevent engagement in a situation with weak outcomes for both parties. This model has its origin in Blake and Mouton's managerial grid, that is why it proposes an approach how to manage the conflict.

Janusz Sztumski has a different position on the issue of ending the conflict, he rather focuses on the possibilities of overcoming conflicts, which makes him more inclined to agree with the thesis about avoiding, mitigating, and preventing conflicts than managing them ${ }^{7}$. His approach is construc-

6 J.Z. Rubin, D.G. Pruitt, S.H. Kim, Social Conflict. Escalation, Stalemate, and Settlement, New York 1994, p. 28.

7 J. Sztumski, Konflikty społeczne i negocjacje jako sposoby ich prze- 
tive, as it indicates the conditions for an effective overcoming of conflicts or dealing with conflicts. The first condition of conflict overcoming is noticing alarm signals, symptoms of the upcoming conflict, i.e., perceived causes, often indirect, which are not clearly visible. The sources of such hidden signals can be disruptions in communication, but also subjective causes such as superstitions, stereotypes, prejudices, hidden or unconscious needs, violated but not explicitly value of one of the parties, and others. The second condition for effective conflict control is a thorough analysis of its specificity, considering the parties, the subject of dispute, scope, causes, contradictions, and intensity of the conflict. Interpretation of the situation allows to choose the right means and methods that allow to properly minimize the negative consequence and strengthen the positive effects of the situation.

Nowadays, many researchers of social conflict emphasize the necessity of conflict management, understood as the process of selecting methods and techniques for effective problem solving, fostering an integrative agreement ${ }^{8}$, not just termination the conflict.

\section{Conflict resolution as a method of solving conflicts and their consequences}

The history of a conflict resolution concept has a long history and its own development ${ }^{9}$. Conflict resolution is a com-

zwyciężania [Social Conflicts and Negotiations as ways of Overcoming them], Częstochowa 2000.

8 P.J. Carnevale, Creativity in the Outcomes of Conflict, op.cit., p. 417.

9 L. Kriesberg, The Evolution of Conflict Resolution, [in:] The Sage Handbook of Conflict Resolution, eds. J. Bercovitch, V. Kremenyuk, I. William Zartman, Thousand Oaks 2009. 
plicated process, so to be effective it must meet the following conditions ${ }^{10}$ :

1. Analytical, that is, revealing and defining the needs of both parties of the conflict to accept and understand them properly, together with the consequences of not being able to satisfy them.

2. Facilitation, that is, attempts by both parties to the conflict to interact in such a way as to allow consideration of possible options for resolution.

3. Search, that is, avoiding any formal obligations before the parties reach an agreement.

4. Resolution, that is, achieving a result that is acceptable to both parties and is socially acceptable, because reaching an agreement cannot occur at any social cost.

Conflict resolution is in a sense the last democratic response of a globalized world where aspects of justice and legitimacy now matter as much as power and order ${ }^{11}$.

The necessity to resolve a conflict arises from difficulties in satisfying human needs and realizing cultural values, as well as from people's aspirations to achieve goals, which objective is to achieve social stability. If one of the adversary parties feels that it has enough strength to defeat its opponents or that it cannot agree to dialogue with its opponents, then none of the techniques for reaching an agreement will be effective. The reasons for such persistent positions are psychological or political. There are, however, many examples of situations where people with strong political power or authority sought dispute resolution and were prepared to

10 J.W. Burton, Conflict: Resolution and Provention, London 1993, p. 217 and further.

11 J. Bercovitch, R. Jackson, Conflict Resolution in XXI Century. Principles, Methods and Approaches, Ann Arbor 2012, p. 184. 
begin the conflict resolution process. This situation occurs when the parties understand the nature of the conflict and the process of its management. The basis of the conflict resolution process is always the willingness and good will of the parties to search for it. The cost of a conflict may be more expensive than the costs of finding a solution. One of the more important questions that the parties should answer is the question of preferences: is it better to bear the high costs of continuing the conflict by not agreeing to any way of resolving it, or by understanding the nature of the conflict and its causes, which are non-negotiable needs, to decide to start a long but less costly process to resolve this situation. The answer to such a formulated problem is particularly important for a possible third party asked to intervene. For many theoreticians of social conflict, Burton's position on non-negotiability conflicts caused by the inability to meet human needs allows for the formulation of a thesis that in such cases it is necessary to use a third party as a mediator.

For Burton, resolving a conflict is not about reaching an agreement between the two parties to the conflict, but about considering the broad social dimension of a given situation and building an environment that will promote valuable relationships between these parties ${ }^{12}$. He distinguishes the methods of conflict resolution as problem-solving method and conflict provention. The first method initiated by Robert Angell is to discover how both sides perceive the properties of conflict. Conflict resolution is an interactive process involving parties that analyse problems with particular emphasis on the human level and the long-term costs of

12 J.W. Burton, Conflict: Resolution and Provention, op.cit., p. 47. 
possible options to solve a given situation ${ }^{13}$. A conflict resolution is a problem-solving process that has the following characteristics ${ }^{14}$ :

1. the solution is not an end-product, but it only establishes new relationships between the parties that have potential problems; it is an ongoing process than a final determination;

2. this process requires the use of new solutions, new techniques, and changes in the conceptualization of a problem;

3. the problem-solving takes into account the total environment, not only the directly involved actors;

4. the effective problem-solving is an analysis of sources and all possible factors happened in the past.

Resolution and conflict provention are methods recognized by Burton as effective in resolving contemporary conflict situations. The concept of conflict resolution became a platform for the discussion of conflicts in the mid-1960s and replaced the concepts of settlement and conflict management ${ }^{15}$. The term 'provention' is invented by the Australian scientist to avoid using the term 'prevention' which has a negative connotation. The conflict provention is an extension of the resolution to adapt socio-political systems to people, not the other way around ${ }^{16}$. Burton distinguishes two types of changes: primary, characterized by the lack of the possibility of human influence, such as weather, population growth, etc., and second-order change - resulting from

\footnotetext{
13 Ibidem, p. 167.

14 Ibidem, pp. 202-203.

15 Ibidem, p. 83.

16 Ibidem, p. 236.
} 
conscious human activity. Conflicts are caused by secondary changes, the inevitability of which is typical for modern societies. Hence, the need to adapt the conflict resolution as an effective method of solving problems resulting from secondary changes ${ }^{17}$.

Burton introduces the concept of conflict provention, which he defines as activities aimed at removing accidental conditions of conflict and the positive promotion of such a social environment that will support cooperative relations. The concept of conflict provention is an alternative to the concept of conflict resolution. Conflict resolution means two sides of the conflict and a specific issue to be resolved, e.g., an ethnic conflict resulting from constitutional arrangements does not require the analysis of past events, but only the adaptation of emotions and needs to a specific situation that will bring the parties to the dispute solved. The conflict provention requires considering the entire social context of the conflict and its sources. The analysis of the conditions that preceded the conflict situation and the analysis of social relations become the main tools of this concept. Provention is specific actions dealing with general social problems, with particular emphasis on those that lead to conflict as well as those elements of the social environment that mitigate the conflict. According to Burton, this concept is particularly important when analyzing contemporary conflicts, such as: terrorism, gang violence, international conflicts, and conflicts with the criminal world. It is the concept that emphasizes that contemporary conflicts are very complicated social phenomena, therefore it is not enough just to solve them, it is necessary to make provention, i.e., to analyze the social background as

17 Ibidem, p. 248. 
broadly as possible to find the most long-lasting way to resolve the conflict.

The conflict resolution process is influenced by many determinants of a conflict situation, such as social, cultural, psychological, economic, political, etc. However, it is necessary to point out some additional factors occurring in the final stage of the conflict development. Morton Deutsch points to two orientations in the approach to conflict resolution in his theory: cooperative and competitive. A constructive solution to a conflict is facilitated by a cooperative orientation, while a competitive orientation makes it difficult ${ }^{18}$. The specific processes and results triggered by a certain type of social relationship led to the emergence of this type of social relationship. Additional factors determining the direction of the conflict are power, social perception, creativity, personality, and many others. Another factor relevant to the conflict resolution process is the experience of those involved in a given situation. From childhood, every person is an observer, participant, and subject of conflicts, thus gathering knowledge about them. However, the acquired knowledge has the nature of tacit knowledge, i.e., many people are not aware of their extensive experience in this field and therefore cannot effectively implement the known methods.

For years, psychologists have been paying attention to the emotional problem of conflict resolution. The lack of a satisfactory solution of the conflict is the cause of many diseases and neuroses, depression, and the lack of adaptation to life in society. A firm resolution of a conflict is a disadvantage for society, but it is fundamental for the human psyche. Separat-

18 M. Deutsch, Cooperation and Competition, [in:] The Handbook of Conflict Resolution. Theory and Practice, eds. M. Deutsch, P.T. Coleman, E.C. Marcus, San Francisco 2006, p. 33. 
ing intrapersonal conflicts from social conflicts is incorrect, as each conflict situation is socio-psychological. The theory of frustration-aggression, the concept of Sigmund Freud, and many others emphasize the psychological sources of conflicts and the impact of these aspects on the course and ending of the conflict.

According to Horowitz, the psychological determinants of ethnic conflict mean that this type of conflict cannot be solved by the manipulation of material benefits, often used in both political and economic negotiations ${ }^{19}$. Analyzing contemporary ethnic conflicts in selected regions of the world, he distinguishes the following methods of ethnic conflict reduction $^{20}$ :

1. political solutions to meet the needs and interests of both parties, e.g., changing the policy so as not to contribute to the disclosure of ethnic conflict, introducing appropriate electoral systems, introducing preferential programs that affect social stratification (e.g., education or profession preferences);

2. separation of the parties;

3. international intervention.

In addition to the above-mentioned methods, when analysing conflicts in Asia and Africa, he notices five mechanisms to reduce ethnic conflict ${ }^{21}$ :

1. the dispersion of power by strengthening local government;

2. highlighting intraethnic conflicts;

19 D.L. Horowitz, Ethnic Groups in Conflict, Berkeley 2000, p. 566.

20 Horowitz does not define what he means by conflict resolution. In his work, he uses the terms solution, resolution and reduction interchangeably, although he most often writes about conflict reduction.

21 D.L. Horowitz, Ethnic Groups in Conflict, op.cit., p. 598. 
3. stimulating interethnic cooperation;

4. encouraging the formation of coalitions based on nonethnic interests;

5. reducing disparities between ethnic groups to reduce the level of dissatisfaction.

In each theoretical approach to conflict, the sources of conflict are interpreted differently, which must result in different conflict resolution strategies. For example, according to Ross, who examines cross-cultural differences in conflict and prefers using the term 'constructive conflict management', the effectiveness of conflict management depends on taking into account two aspects: social structural interests and the psychocultural interpretation of the opponents' motives. The first aspect determines the selection of targets, the second has an impact on the level of conflict and violence ${ }^{22}$.

Representatives of diplomacy and people analysing international relations have a different approach to the conflict resolution strategy. In international conflicts, a strategy is used which, being an alternative to the traditional diplomatic route, is called the second diplomatic path (Track Two Diplomacy). Its idea is to use broad contacts and exchange of views between the opposing parties in a less formal way, which replace traditional diplomatic methods. It consists in building bridges between conflicting parties on the international arena ${ }^{23}$. In that concept, conflict resolution techniques use a wide range of communication tools such as

22 M.H. Ross, The Management of Conflict. Interpretation and Interest in Comparative Perspective, New Haven 1993, p. 10.

23 J. Montville, The Arrow and the Olive Branch: A Case for Track Two diplomacy, [in:] The Psychodynamics of International Relationships, eds. V. Volkan, J.V. Montville, D.A. Julius, Lexington 1991, Vol. 2, pp. $161-175$. 
seminars, workshops, cooperation with the media to shape public opinion, development of economic cooperation, institutional support to strengthen all forms of cooperation, supporting cultural exchange between opposing parties, etc. The principles of diplomacy and international law are aspects influencing the process of conflict resolution.

As Kriesberg stresses, the field of conflict resolution (CR) is becoming more differentiated, but it is going to increase in size and societal penetration in the future ${ }^{24}$. In the literature, apart from various approaches, methods and techniques of conflict resolution, one can also find a division into traditional $\mathrm{CR}$ and post-cold war $\mathrm{CR}^{25}$. As authors of the book "Conflict Resolution in the Twenty-First Century" stress, with the end of Cold War, an increasingly crucial issue influencing conflicts and their dynamics is identity ${ }^{26}$.

In times of widespread globalization and increasingly powerful media, especially social media, conflicts increasingly, both international and internal, concern the identity of local communities, various social groups and individuals. Conflicts aimed at defending identity and respecting human rights are becoming increasingly significant. Social media plays a role in this, on the one hand, as a medium that disseminates content in defense of people's identity, but also as a carrier of social divisions resulting from identity differences. Adding to this ever-stronger power of multinational corporations taking over the functions of government, it turns out that the traditional approach to conflict management,

24 L. Kriesberg, The Evolution of Conflict Resolution, op.cit., p. 18.

25 J. Bercovitch, R. Jackson, Conflict Resolution in XXI Century, op.cit., p. 14 and further.

26 Ibidem, p. 32. 
where legal authorities are elected in democratic processes, has less and less potential to resolve conflicts between representatives of different identities. Contemporary conflicts ranging from conflicts in access to natural sources, through conflicts for the recognition of identity (religious, national, racial, ethnic, sexual, etc.) to conflicts in equal access to rights, both those resulting from the Universal Declaration of Human Rights and those resulting from formal legal regulations, make the humans needs the most important in the process of conflict resolution, about which Burton and other followers of his understanding of the conflict wrote more than 30 years ago. Therefore, it is so important to consider the stages of conflict development, from its sources - direct and indirect, through dynamics - escalation and searching for ways out, to ending the conflict, which is a conscious or unconscious choice of a method of conflict solution that will end it, not just freeze it ${ }^{27}$. As the authors of "Conflict Resolution in XXI Century" stress: ... modern conflict management recognizes the importance and potential of local actors, the different ways war is experienced by men and women, and the need for both official and unofficial channels of communication ${ }^{28}$.

Traditional conflict resolution has advantages and disadvantages. The advantage is searching for a method to stop the violence. The disadvantage is the lack of understanding of the needs of the opposing parties, resulting from their sense of identity and recognition, as well as the difficulty

27 A. Adamus-Matuszyńska, Konflikt społeczny w świetle wspótczesnych teorii [Social conflict in the Light of Contemporary Theories], Katowice 2019.

28 J. Bercovitch, R. Jackson, Conflict Resolution in XXI Century, op.cit., p. 16. 
in understanding the differences in values, which are often indirect causes of conflict.

Traditional CR methods are:

a. negotiations that require awareness of the interests of the opponent parties and good will to find a satisfactory solution;

b. mediation, the intervention of a third, neutral party of the conflict that requires an objective analysis of the needs of the disputed parties;

c. arbitration, which is a form of legal conflict resolution, without the involvement of opposing parties in the resolution process;

d. intervention by a third party through the involvement of international global organizations that rather protect global peace than solving the problem of the opponent parties;

e. peacekeeping, an interstate conflict resolution, which rather strives for international peace, without understanding the needs and values of local actors.

New - meaning the Twenty-First century - approaches to conflict resolution are as follows:

a. preventive diplomacy (conflict prevention) focuses on prevention rather than cure, to reduce the potential for violence and destruction and finally to create conditions to encourage peaceful resolution; it is a proactive, not reactive action ${ }^{29}$;

b. humanitarian intervention is a multidimensional approach to violent conflicts, and it combines diplomatic as well as local level mediation and conciliation ${ }^{30}$; it is

29 J. Bercovitch, R. Jackson, Conflict Resolution in XXI Century, op.cit., p. 89.

30 Ibidem, p. 101. 
designed to supervise transitions from conditions of social conflict to minimal political order ${ }^{31}$;

c. regional task sharing is a concept in which regional organizations or groupings undertake primary responsibility for preventive diplomacy, mediation, peacekeeping, peace-enforcement, and peacebuilding activities within their geographical area ${ }^{32}$;

d. nonofficial diplomacy, sometimes called as Track II diplomacy, is defined as the interaction between private citizens or groups of people within a country or from different countries who are outside the formal governmental power structure ${ }^{33}$; as Burton emphasizes such an approach to resolve conflicts needs to start by an analysis of the interests, needs and values of the parties because these cannot be suppressed by major force ${ }^{34}$;

e. reconciliation and justice approach which is the consequence of the internationalization of justice ${ }^{35}$ and greater respect for human rights in more and more societies; the most important component of this approach is the notion that those who were divided by hostility must be prepared to imagine a common future ${ }^{36}$;

31 J. Chopra, Introducing Peace-Maintenance, [in:] The Politics of Peace-Maintenance, ed. J. Chopra, Boulder 1998, pp. 1-18.

32 J. Merrills, International Dispute Settlement, $4^{\text {th }}$ ed. Cambridge 2012.

33 J.W. McDonald, Introduction, [in:] Conflict Resolution. Track Two Diplomacy, eds. J.W. McDonald, D.B. Bendahamane, Washington, D.C. 1995, p. 1.

34 J.W. Burton, Tract Two: Alternative to Power Politics, [in:] Conflict Resolution. Track Two Diplomacy, eds. J.W. McDonald, D.B. Bendahamane, Washington, D.C. 1995, p. 88.

35 E. Newman, Transitional Justice: The Impact of Transnational Norms and the UN, "International Peacekeeping" 2002, Vol. 9, No. 2, pp. 31-50.

36 J. Bercovitch, R. Jackson, Conflict Resolution in XXI Century, op.cit., p. 152. 
f. peacebuilding understood as an action to identify and support structures which tend to strengthen and peace solidify to avoid a relapse into conflict ${ }^{37}$; it is a multidimensional project which involves many actors simultaneously working at different levels and in different areas to create conditions for development.

Each of the CR methods mentioned has its own functions, advantages, and disadvantages as well as a set of techniques which allow to make a constructive analysis and solve the problem between two opposite parties. Conflict resolution is not a simple outcome. However, it is a complex process of de-escalation and reconciliation that develops to the point where a new qualities and mechanisms exist in the relationship to allow for constructive settlement of disputes ${ }^{38}$.

\section{Asia as a continent of conflicts}

The Asian continent, like any other continent in the world, is and will probably be a field of conflicts, both internal and international ${ }^{39}$. Disputes and wars on this great continent often take place next to sunbathing tourists or close to a flourishing business. In the years 1946-2005, 29\% of world conflicts took place on this continent, more was only in Africa $(32 \%)^{40}$. However, it should be stressed that Asia since

37 B. Boutros-Ghali, An Agenda for Peace. A/47/277-S2411 1992, http://www.un.org/Docs/SG/agpeace.html [access: 18.05.2021].

38 R.J. Fisher, Interactive Conflict Resolution, New York 1997, p. 8.

39 See: A. Bartnicki (ed.), Zarys dziejów Afryki i Azji. Historia konfliktów 1869-2000 [Outline of the Histroy of Arcia and Asia. History of Conflicts], Warszawa 2000.

40 J. Bercovitch, R. Jackson, Conflict Resolution in XXI Century, op.cit., p. 3. 
1980 is rather a continent of peace. Many Asian countries have entered the path of rapid economic development and are successful in this respect, but at the same time, there is a threat to peace in this continent due to the existing nuclear threat or the growing role of China, which may threaten stabilization in the entire region.

The reason there is the absence of major, painful conflicts in the region is the expansion of democracy and economic development. In 2015, according to data provided by the Uppsala Conflict Data Program (UCDP), 15 conflicts were active in Asia including Afghanistan, India, Pakistan, Myanmar, the Philippines, and Thailand. Although none of them were classified as inter-state wars ${ }^{41}$.

However, the following types of conflict should be noticed when analysing disputes in this great continent. Firstly, there are some countries which are post-Soviet, and which may suffer from conflicts due to their past and struggle to find their political and economic position in the region. For example, the years of independence for Kyrgyzstan and Tajikistan have been marred by conflicts on the borders of their Batken and Sughd provinces. Some reports say that in the period from 2011 to 2013, there were 63 incidents on the Kyrgyz-Tajik border, ranging from small fights to hostage taking ${ }^{42}$.

Secondly, the Asian countries are very culturally, politically, socially, and ideologically diverse societies, what in history was and often still is the cause of tensions, conflicts,

41 Ch.M. Lee, Asia's new long march: bottling conflicts and managing political turbulences, “The Pacific Review” 2017, Vol. 30, No. 6, p. 853.

42 K. Toktomushev, Understanding Cross-Border Conflict in Post-Soviet Central Asia: The Case of Kyrgyzstan and Tajikistan, "Connections QJ" 2018, Vol. 17, No. 1, pp. 21-41. 
and wars. At the same time, Asia is a continent that experiences many natural disasters. Therefore, an important element which sometimes is the cause but in other cases the result, are social conflicts over access to natural sources, natural disasters, or the intervention of international corporations that are looking for opportunities to exploit the natural resources of this continent.

The first type of this kind of conflict which occur in this continent is water conflict. When the Central Asian republics became independent in 1991, the transformation process challenged the distribution of water among the countries and this resulted in a conflict of interests. However, it is to be found that the problem is so important to the community and its leaders that cooperation has replaced conflicts between countries ${ }^{43}$.

Southeast Asia experiences forest and land conflicts. Many people are affected by such conflicts, for example, in Indonesia in the years 1990-2000, more than 12 million people were touched by them ${ }^{44}$. Such tensions have an impact on the economy due to its consequences for business. On the other hand, they are seen as a starting point for positive change and for the development of collective actions ${ }^{45}$. More conflicts over forests are widespread in Southeast Asia, they

43 J. Sehring, Unequal distribution: Academic knowledge production on water governance in Central Asia, "Water Security" 2020, Vol. 9, pp. 1-6.

44 A. Dhiaulhaq, T. De Bruyn, D. Gritten, The use and effectiveness of mediation in forest and land conflict transformation in Southeast Asia: Case studies from Cambodia, Indonesia and Thailand. "Environmental Science \& Policy" 2015, Vol. 45, pp. 132-145.

45 A. Castro, E. Nielsen, Indigenous people and co-management: implication for conflict management. "Environmental Science \& Policy" 2001, Vol. 4, No. 4, pp. 229-239; A. Dhiaulhaq, T. De Bruyn, D. Gritten, The use and effectiveness of mediation in forest and land conflict transformation in Southeast Asia, op.cit. 
often occur between indigenous people and/or local communities and external organisations, such as mining companies, plantation estates and conservation agencies ${ }^{46}$.

As the research discloses, natural disasters unite rather than divide people who suffer from natural crisis. The damage and destruction tend to increase 1 cooperation and cohesion on the local level. However, it should be emphasized that the factor which fosters social conflict during such crises is the uneven and irregular distribution of reconstruction aid ${ }^{47}$.

The protection of natural sources also generates conflicts. These conflicts are extremely complex, and thus difficult to solve, as they are particularly dependent on legal regulations, the management of natural sources, governance conditions and economic goals in a particular region. As some case studies explained, such conflicts varied with respect to natural resource systems, actors, governance, and the degree of reserve-village tensions. In one of the cases, competitive interests against the alternative of protecting natural resources or using them for the development of, for example, tourism, generate local conflicts. In the other one, such situation did not generate strong conflict due to the polycentric governance system with strong self-organization and networking processes ${ }^{48}$.

46 Y. Yasmi, L.C. Kelley, T. Enters, Community-outsider conflicts over forests: Perspectives from Southeast Asia, "Forest Policy and Economy" 2013, Vol. 33, https://doi:10.1016/j.forpol.2012.05.001 [access: 18.05.2021].

47 A. De Juan, J. Pierskalla, E. Schwarz, Natural disasters, aid distribution, and social conflict - Micro-level evidence from the 2015 earthquake in Nepal, "World Development" 2020, Vol. 126, https://doi. org/10.1016/j.worlddev.2019.104715 [access: 16.05.2021].

48 Y. Zhang et al., Conflict between nature reserves and surrounding communities in China: An empirical study based on a social and ecological system framework, "Global Ecology and Conservation" 2020, Vol. 21, https://doi.org/10.1016/j.gecco.2019.e00804 [access: 18.05.2021]. 
Concluding some issues connected with the conflicts due to environmental issues, it must be stressed that Asia, as many other regions in the world, faces the environmental and social costs of resource exploitation which have risen conflicts against such a form of economic development. Socioecological conflicts are forms of struggle associated with the unequal access to, distribution of, and control over natural resources $^{49}$. Nationalist language policy is provoking protests in many countries, such as Pakistan, Sri Lanka and India ${ }^{50}$.

Asia is a continent which, in its long history, has created conditions for the development of a very rich and diverse culture, which consists of many religions, languages, various value systems and norms. This diversity creates divisions rooted in different values. As Burton writes, Preservation of values is a reason for defensive and aggressive behaviours. (...) It is values that have divided Lebanon, Northern Ireland and many other multi-ethnic and multi-communal societies ${ }^{51}$. Religion is often a cause of social conflicts. It is no different in Asian countries, as in many others in the world, e.g., in Thailand or the Philippines, where cultural practices are the cause of violent conflicts ${ }^{52}$.

49 P. Hirsch, Warren C. (eds.), The politics of environment in Southeast Asia: Resources and resistance. London: Routledge 1998; M. Pichler, A. Brad, Political ecology and socio-ecological conflicts in Southeast Asia. "ASEAS - Austrian Journal of South-East Asian Studies" 2016, Vol. 9, No. 1, pp. 1-10.

50 P. Sethy, The Role of the State: Pathways from Ethnolinguistic Nationalism to Conflict in South Asia, "Journal of International Affairs" 2019, Vol. 73, No. 2, pp. 95-117.

51 J.W. Burton, Conflict: Resolution and Provention, London 1993, p. 37.

52 S. Barter, I. Zatkin-Osburn, Shrouded: Islam, war, and holy war in Southeast Asia, "Journal for the Scientific Study of Religion" 2014, Vol. 53, No. 1, pp. 187-201. 
Asia is also not a continent free from terrorist activities, especially active in the Malay Archipelago. Since the terrorist attacks in 11/9 2001, intensive actions for regional security have also been launched in Asian countries. However, so far, no permanent structure has been built on this continent to ensure regional security. It turns out that the development of regional economy contributes much more to the creation of a security system in this region, which is more effective than the numerous political and military structures created ${ }^{53}$.

\section{Conclusion}

Asia, as a large and diverse continent, is an area of many various conflicts. One may notice that there, is an interest in conflict resolution practices. For example, the Korean government established $\mathrm{CR}$ working groups by presidential decree and allocated funding for CR education from elementary to college level $^{54}$.

However, there are not many examples of CR practices and their effectiveness in solving tensions and conflicts. There is a question why so effective in Africa, Europe CR practice, does not have a positive impact in this continent. To answer such a question, it is worth to go back to the Burton's theory of conflict. John Burton identifies three fundamental causes of conflict situations: interests, values and needs ${ }^{55}$. Values are

53 D. Czywilis, Wojna z terroryzmem międzynarodowym w Azji Południowo-Wschodniej: reintegracja systemu bezpieczeństwa? [War on International Terrorism in Asia Southeast: Reintegrating the Security System?], [in:] Bezpieczeństwo wspótczesnej Azji [Security of modern Asia], ed. J. Marszałek-Kawa, Toruń 2014, pp. 65-84.

54 L. Kriesberg, The Evolution of Conflict Resolution, op.cit. p. 15

55 J.W. Burton, Conflict: Resolution and Provention, op.cit., p. 36 and further 
ideas, customs, habits, and beliefs specific to a given community. They are class, ethnic, religious, cultural, or other in nature, contributing to the differentiation of individual cultures and group identity. Values differ from needs in terms of their universal character, primordiality and passing from one generation to the next. In a situation of discrimination, isolation, and violence, the defense of values is the main task to meet the needs of personal and/or group security. Preserving values can cause defensive and aggressive behavior. Values are the basis for shaping group identity, which in turn enables the individual to move around the world, gives a sense of security and a sense of cultural belonging.

Burton recognizes value as an important element of cooperation, although he emphasizes that certain common values are hidden and this is the cause of the lack of cooperation between people, because people focus on the values that divide them, not recognizing the ones that they have in common and unite them.

The second cause of conflicts mentioned by Burton are the needs, or rather the inability to meet them. According to him, the theory of human needs allows us to understand both the causes of conflicts and the behavior of their direct participants. Needs are the inherent driving force of an individual's development and the strength that allows him/her to survive. If difficulties in meeting needs occur on a larger social scale, society falls into an anomy and conflicts become the main element of social relations. According to Burton, the fulfillment of needs is an opportunity for the personal development of an individual, satisfying needs in society is a sine qua non condition for the harmonious development of society ${ }^{56}$.

56 J.W. Burton, Deviance, Terrorism and War: The Process of Solving Unsolved Social and Political problems, Oxford 1979, pp. 79-81. 
The fundamental objective of conflict resolution is to achieve a new quality and new mechanisms in relations between the disputing parties. In a situation of conflict over values, and this dominates in Asian countries, such a result is probably impossible. The parties to the conflict would have to be more flexible towards their established over the centuries cultural values and norms. They are a significant barrier not only in achieving peace, but in the use of both traditional and new CR methods. As research shows, systematic economic expansion and the creation of conditions for the development of the region, country and individuals are the mechanisms that violate the traditional values of Asian cultures in the smallest way, and therefore the economy development reduces the number as well as intensity of numerous conflicts on this continent.

\section{Bibliography}

Adamus-Matuszyńska A., Konflikt społeczny w świetle wspótczesnych teorii [Social conflict in the Light of Contemporary Theories], Katowice 2019.

Barter S., Zatkin-Osburn I., Shrouded: Islam, war, and holy war in Southeast Asia [Outline of the History of Africa and Asia. History of Conflicts 1869-2000], "Journal for the Scientific Study of Religion" 2014, Vol. 53, No. 1.

Bartnicki A. (ed.), Zarys dziejów Afryki i Azji. Historia konfliktów 1869-2000, Warszawa 2000.

Bercovitch J., Jackson R., Conflict Resolution in XXI Century. Principles, Methods and Approaches, Ann Arbor 2012. Boutros-Ghali B., An Agenda for Peace. A/47/277-S2411, 1992, http://www.un.org/Docs/SG/agpeace.html. 
Burton J.W., Conflict: Resolution and Provention, London 1993.

Burton J.W., Deviance, Terrorism and War: The Process of Solving Unsolved Social and Political problems, Oxford 1979.

Burton J.W., Tract Two: Alternative to Power Politics, [in:] Conflict Resolution. Track Two Diplomacy, eds. J.W. McDonald, D.B. Bendahamane, Washington 1995.

Carnevale P.J., Creativity in the Outcomes of Conflict, [in:] The Handbook of Conflict Resolution. Theory and Practice, eds. M. Deutsch, P.T. Coleman, E.C. Marcus, San Francisco 2006.

Castro A., Nielsen E., Indigenous people and co-management: implication for conflict management, "Environmental Science \& Policy” 2001, Vol. 4, No. 4.

Chopra J., Introducing Peace-Maintenance, [in:] The Politics of Peace-Maintenance, ed. Jarat Chopra, Boulder 1998.

Czywilis D., Wojna z terroryzmem międzynarodowym $w$ Azji Potudniowo-Wschodniej: reintegracja systemu bezpieczeństwa? [War on international terrorism in Southeast Asia: reintegrating the security system?], [in:] Bezpieczeństwo wspótczesnej Azji [Security of modern Asia], ed. J. Marszałek-Kawa, Toruń 2014.

de Juan A., Pierskalla J., Schwarz E., Natural disasters, aid distribution, and social conflict-Micro-level evidence from the 2015 earthquake in Nepal, "World Development" 2020, Vol. 126, https://doi.org/10.1016/j.worlddev.2019.104715.

Deutsch M., Cooperation and Competition, [in:] The Handbook of Conflict Resolution. Theory and Practice, eds. M. Deutsch, P.T. Coleman, E.C. Marcus, San Francisco 2006. 
Dhiaulhaq A., De Bruyn T., Gritten D., The use and effectiveness of mediation in forest and land conflict transformation in Southeast Asia: Case studies from Cambodia, Indonesia and Thailand. "Environmental Science \& Policy" 2015, Vol. 45.

Fisher R.J., Interactive Conflict Resolution, New York 1997.

Galtung J., Violence, War and the Aftermath: On Visible and invisible consequences of violence and what to do about Them (typscript), 1996.

Harrison F., Do dziś liczymy zabitych. Nieznana wojna w Sri Lance, Wołowiec 2015.

Hirsch P., Warren C. (eds.), The politics of environment in Southeast Asia: Resources and resistance, London 1998. Horowitz D.L., Ethnic Groups in Conflict, Berkeley 2000. Kriesberg L., The Evolution of Conflict Resolution, [in:] The Sage Handbook of Conflict Resolution, eds. J. Bercovitch, V. Kremenyuk, I. William Zartman, Thousand Oaks 2009. Lee Ch.M., Asia's new long march: bottling conflicts and managing political turbulences, "The Pacific Review” 2017, Vol. 30, No. 6.

McDonald J. W., Introduction, [in:] Conflict Resolution. Track Two Diplomacy, eds. J.W. McDonald, D.B. Bendahamane, Washington, D.C. 1995.

Merrills J., International Dispute Settlement ( $4^{\text {th }}$ ed.), Cambridge 2005.

Montville J., The Arrow and the Olive Branch: A Case for Track Two diplomacy, [in:] The Psychodynamics of International Relationships, eds. V. Volkan, J.V. Montville, D.A. Julius, Lexington 1991, Vol. 2.

Newman E., Transitional Justice: The Impact of Transnational Norms and the UN, "International Peacekeeping" 2002, Vol. 9, No. 2. 
Pichler M., Brad A., Political ecology and socio-ecological conflicts in Southeast Asia, "ASEAS - Austrian Journal of South-East Asian Studies" 2016, Vol. 9, No. 1.

Ross M.H. (1993). The Management of Conflict. Interpretation and Interest in Comparative Perspective, New Haven 1993.

Rubin J.Z. Pruitt D.G., Sung Hee Kim, Social Conflict. Escalation, Stalemate, and Settlement, New York 1994.

Sehring J., Unequal distribution: Academic knowledge production on water governance in Central Asia, "Water Security" 2020, Vol. 9.

Sethy P., The Role of the State: Pathways from Ethnolinguistic Nationalism to Conflict in South Asia, "Journal of International Affairs" 2019, Vol. 73, No. 2.

Sztumski J., Konflikty społeczne i negocjacje jako sposoby ich przezwyciężania [Social Conflicts and Negotiations as Ways of Overcoming them], Częstochowa 2000.

Toktomushev K.,Understanding Cross-Border Conflict in Post-Soviet Central Asia: The Case of Kyrgyzstan and Tajikistan, "Connections QJ" 2018, Vol. 17, No. 1.

Wright Q., The Nature of Conflict, [in:] Conflict: Readings in Management and Resolution, eds. J. Burtona, F. Dukesa, Londyn 1990.

Yasmi Y., Kelley L.C., Enters T., Community - outsider conflicts over forests: Perspectives from Southeast Asia, "Forest Policy and Economy” 2013, Vol. 33, doi:10.1016/j. forpol.2012.05.001.

Zhang Y., Hu Y., Zhang B., Li Y., Zhang X., Xie Y., Conflict between nature reserves and surrounding communities in China: An empirical study based on a social and ecological system framework, "Global Ecology and Conservation" 2020, Vol. 21. 


\begin{abstract}
Conflict is a universal social phenomenon. Therefore, each society develops its own norms, rules, laws, and institutionalized forms leading to its resolution. Solving the conflict means revealing the causes of a given situation and choosing one of the many alternative options to organize the relations between the parties of the conflict situation. Conflict resolution is a process developed by researchers and practitioners to de-escalate and reconciliate difficult relationships between at least two parties for constructive settlement.

The paper considers whether such an approach can be successfully practiced in the Asian countries which are very culturally, politically, socially, and ideologically diverse societies. The fundamental objective of conflict resolution is to achieve a new quality and new mechanisms in relations between the disputing parties. In a situation of conflict over values, which dominates in Asian countries, such a result is probably impossible.
\end{abstract}

Keywords: conflict, conflict resolution, Asia, diversity, dispute 


\section{Monica A. Fennell}

Pro Bono Director, Taft, Stettinius \& Hollister, and Part-time Assistant Professor, Honor Scholar Program, DePauw University, Greencastle, Indiana, U.S.A. J.D., 1993, Georgetown University Law Center, Washington, D.C., U.S.A. B.A., 1987, Williams College, Williamstown, Massachusetts, U.S.A.

\section{Using peace and conflict analysis to spur innovation in access to justice in the U.S. ${ }^{1}$}

\section{Background: Threats to peace and conflict resolution and delivery models for civil legal aid}

An increasing number of people in the United States perceive a need for legal help to resolve civil (not criminal) disputes, but cannot afford to hire a lawyer to help resolve those disputes. ${ }^{2}$ Defendants in criminal cases have free legal assistance through the public defender system paid by the government, a right to counsel founded on the Sixth Amendment to the

1 Article from Peace and Conflict Resolution panel, October 30, 2020, $7^{\text {th }}$ annual International Congress on Asian Studies, Torun, Poland. Special thanks to Rotary International and the Rotary Peace Center at Chulalongkorn University for giving Peace Fellows lucky class 13 the opportunity to learn from amazing peace builders and to explore our peace projects. Portions of this paper were delivered at the $7^{\text {th }}$ annual International Congress on Asian Studies, Torun, Poland, with Peace Fellows colleagues and professors, a panel moderated by Dr. Maria Ochwat.

2 Legal Services Corporation, The Justice Gap: Measuring the Unmet Civil Legal Needs of Low-Income Americans, 2017, pp. 13, 21; see, e.g., V. Quintanilla, R. Thelin, Indiana Civil Legal Needs Study and Legal Aid System Scan, 03.2019. 
U.S. Constitution and the seminal case of Gideon v. Wainwright. ${ }^{3}$ The civil legal needs of those in poverty far outstrip the available resources for free legal help, whether it be legal aid staff attorneys or volunteer attorneys serving pro bono. ${ }^{4}$ This justice gap has been exacerbated by the pandemic. ${ }^{5}$ Many of those in need are turned away by legal aid and pro bono providers due to lack of capacity. ${ }^{6}$

There are a limited number of lawyers willing and able to assist low-income people with their civil disputes for free or "pro bono publico." Even if, for example, all attorneys in the state of Wisconsin served only the legal needs of lowincome families, the sheer number of clients is far greater than the number of lawyers. ${ }^{8}$ Judge Daniel Taubman has documented that, despite this huge need, lawyers may be volunteering less, not more. He proposes a focus on serving people of modest means and revising lawyers' rules of

3 U.S. Constitution, Sixth Amendment; Gideon v. Wainwright, 372 U.S. 335 (1963).

4 Legal Services Corporation, The Justice Gap, pp. 13, 21; see, e.g., Quintanilla and Thelin, Indiana Civil Legal Needs Study; see, e.g., D. Dale, The State of Access to Justice in Oregon, Part 1: Assessment of Legal Needs, p. 51, March 2000.

5 LSC Survey Finds Major Impact of COVID19 Pandemic on Legal Aid, 24 July 2020, https://www.lsc.gov/media-center/press-releases/2020/ lsc-survey-finds-major-impact-covid-19-pandemic-legal-aid [access: 3.04.2021].

6 D. Taubman, Has the Time Come to Revise Our Pro Bono Rules?, "Denver Law Review" 2020, Vol. 97, p. 407; J. Laramore, The Future of Access to Justice, "Indiana Law Review" 2018, Vol. 51, No. 1, p. 27.

7 J. Laramore, The Future of Access to Justice, "Indiana Law Review" 2018, Vol. 51, No. 1, p. 29.

8 D. Molvig, Bridging the Justice Gap: Gauging the Public's Unmet Civil Legal Needs, "Wisconsin Lawyer", April 2007; see also D. Taubman, Has the Time Come to Revise Our Pro Bono Rules?, "Denver Law Review" 2020, Vol. 97, p. 406. 
professional responsibility to highlight the importance of donating legal skills to help those in need. ${ }^{9}$

More and more people are trying to navigate the court system on their own. ${ }^{10}$ People who are not represented by attorneys--self-represented litigants or pro se litigants-often have trouble finding their way in a system that can be technical and complex. ${ }^{11}$ As study concerning legal needs of the poor in Hawaii noted, the legal system "is seen as inaccessible, distant, incomprehensible and at times, punitive... People... deserve to have a justice system that they can believe in and in order to create such a system, it is key to identify the barriers that prevent access to justice."12 Accessibility can mean a lot of things, and more organizations are taking a user-centered design perspective. As self-represented litigants flood the court system, court staff and judges can become overwhelmed, slowing down dispute resolution time for all. ${ }^{13}$ This is particularly true now, when many courts have had to close or limit proceedings during the pandemic and are expecting a tsunami when they open up more. ${ }^{14}$

There are four main types of delivery models for civil legal assistance for low-income people in the U.S. The first

9 D. Taubman, Has the Time Come to Revise Our Pro Bono Rules?, "Denver Law Review" 2020, Vol. 97, pp. 428-441.

10 R. Shepard, The Self-Represented Litigant: Implications for the Bench and Bar, "Family Court Review", September 2010.

11 Asymmetrical representation is also problematic and raises ethical and fairness issues.

12 Hawaii Access to Justice Hui, Achieving Access to Justice for Hawai'i's People, November 2007, p. II-28.

13 R. Shepard, The Self-Represented Litigant: Implications for the Bench and Bar, "Family Court Review", 09.2010.

14 S. Silverman, J. Thornton, Prepare for the Tsunami of Court Cases - It's Coming, 7.08.2020, https://www.law.com/dailybusinessreview/2020/08/07/prepare-for-the-tsunami-of-court-cases-its-coming/ [access: 3.04.2021]. 
is legal assistance programs such as those funded by the Legal Services Corporation ("LSC"), programs that hire staff attorneys to provide the legal assistance and that are often restricted by grant funding to helping certain clients and case types. The second is pro bono programs that rely on volunteer attorneys to provide free legal help to the lowincome community. The third main delivery model is selfrepresented litigant initiatives that provide resources such as forms and instructions for people to proceed pro se, on their own in court. The last main model tries to resolve civil disputes outside of the courtroom through alternative dispute resolution (“ADR"), especially mediation.

\section{Breaking down the conflict}

Using Johan Galtung's conflict analysis triangle of A, B, C (D) can help break down the conflict to shed some light on how this conflict in access to justice delivery models can be resolved. ${ }^{15}$ The U.S. programs using the four main delivery models often fail to collaborate, resulting in low-income people who need legal help being bounced from place to place and increasing the time to reach resolution or increasing the number of people who give up on a resolution. Many of the actors are interested in increasing funding for access to justice, and they denigrate other models in order to promote their own. Some legal aid and pro bono provid-

15 B. Holmberg, Rotary Peace Center at Chulalongkorn University presentation, 25.06.2012; J. Galtung, Violence, Peace and Peace Research, "Journal of Peace Research" 1969, Vol. 6, No. 3, pp. 169-171; Do No Harm Project, Collaborative for Development Action, Inc. and CDA Collaborative Learning Projects, The 'Do No Harm' Framework for Analyzing the Impact of Assistance on Conflict: A Handbook, April 2004. 
ers avoid meaningful evaluation and strategic planning because they are afraid they would result in criticism and loss of funding. There are too few actors and programs willing to conduct such things as shared intake.

\section{Actors - courts, attorneys, funders, NGOs, media, clients, pro se litigants and corporations}

The powerful actors in the legal services delivery models in the U.S. are the highest courts in the states, usually state supreme court justices, though in some states the highest court is called the court of appeals. The state bar associations and private attorneys are the next most influential in terms of changing the legal delivery system and increasing access to justice. The funders and the donors are the next most influential, but they are more scattered and less able to speak with one voice, so there is control in limited areas. Those funders and donors include the federal LSC (using money from the U.S. Congress); donors to programs using all four delivery models; and state legislatures that fund the courts and legal programs. The pro bono, legal aid, alternative dispute resolution and self-represented litigant programs themselves are actors with some influence and control, but their control is generally limited to their specific area of expertise and client base. The media are also an actor, though the court system and legislature do not respond much to the legal media and mainstream media focus on criminal cases. The media are in the sphere of influence and are important in giving a voice to the voiceless, but they are not a powerful actor.

The potential and existing clients and the pro se litigants are the vulnerable actors. They have the least voice in the 
provision of free legal help to those in need. Community organizations serving low-income populations also have little influence in the access to justice arena but do have an interest in seeing that the legal needs are met along with the other needs. Corporations as actors are involved in court cases in the court system and so have a stake in increasing the efficiency and effectiveness of the courts, but are not the main actors, though many in-house counsels at corporations have organized pro bono projects. They are not vulnerable, but are weak in the context of this particular conflict.

\section{Attitudes - follow the money}

Some in the legal aid community think that lawyers at large law firms do not care about people in poverty and only care about money. Thus, they believe that recruiting volunteer attorneys is not worth much effort because only staff attorneys who do poverty law full-time can really do a good job. Their attitude is that the only legal help that is really valid is help that goes to high-poverty clients and that assistance to other low-income clients or other types of legal assistance are not valuable. Legal aid programs have often suffered funding cuts, and they are afraid of losing funding to other types of legal assistance initiatives. They are also afraid of losing power, which they view as being tied to funding.

Some volunteer lawyers, state bar associations, and pro bono professionals think that one-case one-client is the best model and that disputes should be resolved through litigation in court. They believe that time and money should be invested in showcasing the good work of lawyers rather than in providing legal assistance that is not representation, such 
as self-represented litigant initiatives and ADR. Their attitude is that the justice system can best be strengthened by more lawyers taking more cases for free. They are afraid that by recognizing the validity of other means of legal assistance, they are de-valuing legal expertise and will lose paying clients, their livelihood. Some argue that "ADR promotes simply harmony and results in the subordination of legal rights, particularly those of society's less powerful." ${ }^{16}$ This argument is often made in the context of domestic violence and is often raised as a gender issue. One advocate for international alternative dispute resolution described lawyers' conflicting attitudes about alternative dispute resolution as follows: "The rule of law is ... about the supremacy of legal rules with respect to the ordering of human affairs and providing standards for the disputes that inevitably arise....ADR is often thought of as 'private ordering', or the resolution of disputes through standards other than legal rules..." ${ }^{17}$

Courts and judges feel overwhelmed by the increasing number of filings by self-represented litigants, who have difficulty navigating the court system without a lawyer. Some judges worry that the litigants proceeding on their own will not get a fair outcome without legal advice. Although lawyers and judges perceive an increasing need in the area of family law for self-represented litigants, studies concerning legal needs of the poor in the U.S. have actually found that legal assistance providers and courts perceive a greater need for family law help than low-income households do. ${ }^{18}$ Law-

16 R. Reuben, ADR and the Rule of Law: Making the Connection, “Dispute Resolution Magazine”, Summer 2010, p. 5.

17 Ibidem, p. 4.

18 M. Fennell, Using State Legal Needs Studies to Increase Access to Justice for Low-Income Families, "Family Court Review”, October 2010, 
yers and bar associations in the U.S. feel threatened by the number of those who think that they can proceed without a lawyer. ${ }^{19}$

Some ADR programs question whether all disputes where a legal need is identified need to have a lawyer involved and need to be in court. ADR programs feel that people in the U.S. are too litigious and that resolving disputes in court just leads to more friction and frustration.

A connector in attitudes is that people and organizations using all four delivery models want to work with the lowincome community to increase access to justice. Another connector is that almost every U.S. lawyer in the access to justice field could be making a lot more money in a private legal practice, and they chose to work in this field because they believe in doing justice, whether it be as a volunteer lawyer, a mediator, or a staff attorney.

A divider in attitudes is the importance or value put on the degree of legal expertise that should be leveraged. Some lawyers see it as de-valuing legal expertise if someone advocates a non-legal solution or a do-it-yourself solution. There are many grievances and anxiety on all sides about which projects receive funding and are perceived as more valued. There are also jealousies about which model or which organizations the state high courts support with funding, with court rules or with court appearances.

\footnotetext{
Vol. 48, p. 619; Task Force on Civil Equal Justice Funding, Washington State Supreme Court, The Washington State Civil Legal Needs Study, September 2003, p. 36.

19 M. Fennell, Ensuring Access to Justice for Self-Represented Litigants, “Judicature”, 3.04.2011, Vol. 94, p. 204.
} 


\section{Behavior - missed collaborations and user-centered design}

The U.S. programs using the four main delivery models often fail to collaborate, resulting in low-income people who need legal help being bounced from place to place and increasing the time to reach resolution or increasing the number that give up on a resolution. Many of the actors are interested in increasing funding for access to justice but feel it is a zero-sum game and thus denigrate other models in order to promote their own. This is a divider. Some in the legal aid community avoid detailed evaluation and strategic planning because they are afraid it will result in criticism or loss of funding. There are few actors and programs willing to consider user-centered design and to do such things as shared intake to evaluate where best to send people who need help. Funders often ask programs using all four delivery models to compete for grants and other funding, which fosters a competitive attitude.

Legal aid programs sometimes use the media to make private lawyers and bar associations look elitist or moneyfocused. ADR programs and self-represented litigant initiatives sometimes denigrate the legal process and try to make courts look ineffective or inaccessible and lawyers look greedy. These are also dividers. The media can be a divider in that they portray lawyers negatively and portray judges as aloof or political, but the media can also be a connector in telling the positive stories of lawyers helping those in need, no matter what the delivery model.

Self-represented litigants often have difficulty maneuvering through the court system without a lawyer. In a 2011 decision by the U.S. Supreme Court, Turner v. Rogers, the 
Court did not provide for a right to counsel, but encouraged courts to develop self-represented litigant initiatives ("substitute procedural safeguards"), including forms and clinics. ${ }^{20}$ This action by the Court was seen as a partial victory for those working on self-represented litigant initiatives and a validation of what they do. ${ }^{21}$ This can serve as a connector between the court system, judges, lawyers, clients, and self-represented litigant initiatives. (For more interests and motivations, see the description of Actors above.)

\section{Contradictions, ethics, poverty and tsunamis}

The four U.S. access to justice delivery models have incompatible goals in that they use different means to address the justice gap. Nonetheless, they are connected by a common respect for courts and for justice, whether or not they use lawyers in court to resolve disputes. The legal aid and pro bono systems are more traditional ways to address the justice gap, and pro se and ADR initiatives are more recent and less traditional. As an American Bar Association manual pointed out, "frequently, individuals who have a problem that has not yet become a bona fide legal issue or who have incomes slightly above the limits... are left without assistance of any kind. While workshops and classes may provide generalized help, many potential clients are turned away and left feeling discounted and helpless."22

20 Turner v. Rogers, 131 S.Ct. 2507 (2011).

21 R. Zorza, Turner v. Rogers, The Implications for Access to Justice Strategies, "Judicature" 2012, Vol. 95, pp. 256-60.

22 American Bar Association, A Manual for Legal Services and Pro Bono Mediation Programs, $2^{\text {nd }}$ Edition, 2007, p. 1. 
In the legal context, court rules and decisions are important structures in place. The ethics rules in many states in the U.S. do not facilitate and even seem to bar limited scope representation, which is a way to combine full-blown representation with a legal aid staff attorney or volunteer lawyer with self-representation for part of the case. The ethics rules also regulate the unauthorized practice of law and define some provision of legal information as legal advice, which only attorneys can do. Many states have ADR rules that bar the use of mediation cases where domestic violence is an issue. Thus ADR can be raised as a gender issue. Court rules are a connector for lawyers in that they are all subject to them, but a divider from non-lawyers who do not see the necessity or logic of some of the rules and a divider between lawyers who think they should be changed to facilitate more pro se initiatives and more ADR. ${ }^{23}$

In the U.S., the poverty of the low-income population who cannot afford to hire a lawyer or mediator for a dispute is also a structure for peace and conflict. Related issues and structures include higher unemployment and climbing eviction rates (including the expected tsunami of eviction and other cases once the pandemic restrictions are lifted). ${ }^{24}$ Although the bad economy can be a divider between clients who forego medicine in order to pay for food and private lawyers who are wealthy and volunteering, it has also proven to be a connector because all are subject to the vicis-

23 M. Fennell, Ensuring Access to Justice for Self-Represented Litigants, "Judicature”, 3.04.2011, Vol. 94.

24 S. Silverman, J. Thornton, Prepare for the Tsunami of Court Cases - It's Coming, 7.08.2020, https://www.law.com/dailybusinessreview/2020/ 08/07/prepare-for-the-tsunamiof-court-cases-its-coming/ [access: 3.04.2021]. 
situdes of the struggling pandemic economy. Foreclosures and evictions are in all neighborhoods, and there has been a good success rate in recruiting new volunteers who see the need and want to help their neighbor. Private lawyers and bar associations have more political power and access than the legal aid programs and then the ADR programs and selfrepresented litigant initiatives. The courts and judges have some political power and access, because many were elected or were appointed by an elected official.

There are chronic funding issues with programs and people involved in all four delivery models, a problem which is exacerbated in this economy. There is a chronic lack of information and transparency, especially since the media mostly cover criminal cases and not civil. Some of the legal needs of the poor studies only look at the problems that low-income people report as legal problems and fail to examine whether those problems are best resolved in court and fail to determine how those needs are being met and how best to meet hose needs. Few cost-benefit analyses have been conducted, losing opportunities to show value to funders. Some studies are also limited to a small region or narrow subject area, such as eviction.

\section{Drivers of peace and conflict in access to justice delivery models in U.S.}

Applying Galtung's triangle, the drivers of peace and conflict in the four competing U.S. delivery models for increasing access to justice are all combinations of attitudes, behaviors and contradictions/structures $(\mathrm{A}+\mathrm{B}+\mathrm{C}=\mathrm{D})$. Drivers include attitudes of fear and anxiety in relation to the lack of funding 
on the part of all four delivery models. Drivers also include a desire to improve the poor perception of lawyers and the legal system, the "troubling anti-adjudication rhetoric," ${ }^{25}$ when the "constitutional concept of courts as a basic public service provided by government is under siege." ${ }^{26}$ Another driver is the desire to serve the dispute resolution needs of the lowincome people and to increase access to justice for all.

Some legal aid organizations are clinging to their traditional way of finding a staff attorney to handle disputes for those who are in dire poverty in certain types of civil cases. This model is lawyer-heavy and thus expensive, though it is retained out of a desire to increase access to justice for those in need. These programs do not collaborate well with the other types of programs in an era of anxiety over reduced funding. The pro bono programs also focus on the traditional one-lawyer one-client model, but leverage resources by using less paid staff to help more people. There is increased clients' satisfaction with the legal system and increased confidence in lawyers because more people are helped, but still a limited number of people have access to this delivery model.

Self-represented litigant projects assist those who do not get direct representation from a legal aid staff attorney or a pro bono volunteer and increase satisfaction with the legal system and get more fair results than no representation. They increase the legal information available and make it easier to understand by providing apps, pamphlets, videos and web-

25 H. Genn, What Is Civil Justice For? Reform ADR and Access to Justice, "Yale Journal of Law \& Humanities" 2012, Vol. 24, p. 398.

26 J. Resnik, Fairness in Numbers: A Comment on ATET v. Concepcion, Walmart v. Dukes, and Turner v. Rogers, "Harvard Law Review" 2011, Vol. 125, p. 80. 
sites. However, not all cases are appropriate for self-representation if the person does not have the requisite literacy level or the case is too complex or there are other special circumstances. There are fewer drivers for conflict here in that they do not receive much funding so there have never been many resources to fight over, but the do-it-yourself attitude can be perceived as threatening to legal institutions.

The do-it-yourself attitude in ADR can also cause conflict with legal institutions, though the ultimate aim is to make the parties more invested and result in creative, winwin or at least improved solutions that free up the courts for disputes which are best resolved through litigation. Mediation is often not advisable for domestic violence and other power imbalance situations. If the parties are unrepresented in ADR, sometimes the mediation can result in legally unworkable solutions.

Given the drivers of this conflict in U.S. access to justice delivery models, the recommendations and options for action include incentives to cooperate, limited scope representation initiatives, public relations for courts, shared intake, better use of media, finding more ways to recruit and involve more lawyers, and the increased use of ADR. For example, if we can resolve disputes before they get to the point of filing a court case or, once they're filed, before the judge holds hearings and makes decisions, we can save time for the parties and potentially get a better result. Mediation could help with the court's backlog of cases during the pandemic, and even after the pandemic there will be more online dispute resolution. ${ }^{27}$ Facilitating dialogue among service

27 See, e.g., M. McBride, ODR in the Era of COVID-19, "American Bar Association Dispute Resolution Committee”, 27.10.2020, https:// www.americanbar.org/groups/family_law/committees/alternative-dis- 
providers could address the attitudes of some of the actors. Using the "do no harm" tool can help identify biases and values here. Increased transparency should help. More training to send paralegals, college students or law students to provide legal information (not legal advice) to self-represented litigants could address some of the drivers. Creating access to justice commission - umbrella organization for all providers - could help address drivers. Programming options should include incentives to stakeholders for power sharing.

\section{Scenarios and recommendations for access to justice initiatives}

In the positive scenario, more volunteer lawyers are willing and able to provide free legal help to those in need and all of the delivery models integrate and cooperate to get more help more efficiently and effectively to more people. In this de-escalation of conflict there would not be a need for an access to justice commission because it might add cost without increasing cooperation. There would be an increase in funding for all four delivery models and a decrease in the number of people who turn to the court system to resolve their disputes. Shared intake could be an option for action, as well as the better use of media to increase transparency and increase confidence in the court system. This should all be made sustainable.

In the neutral scenario where the current situation does not change, people are bounced around, but some eventu-

pute-resolution/odr/. Mediators need to ensure that participants can select the means of remote participation without prejudice. There should be support for those who - for monetary, technical or other reasons cannot fully participate in a remote mediation without assistance [access: 12.04.2021]. 
ally get help, and there is a negative perception of courts and lawyers, though some success stories. Recommendations include incentives to cooperate, limited scope representation initiatives, public relations for courts, shared intake, better use of media, finding more ways to recruit and involve more lawyers, and the increased use of ADR.

In the negative scenario, where there is escalation of the conflict and deterioration, there would be fewer pro bono volunteers, an increase in sniping between initiatives, and less cooperation. Most people would bounce from organization to organization without appropriate help, and some organizations and courts would close for lack of funding. There would be decreased confidence in the judicial system. Recommendations include cooperation incentives, limited scope representation, public relations for courts, and pro bono recruitment initiatives. The increased use of ADR can help find common goals and interests and reduce the impression that it is a zero-sum game, thus building capacity for when the strategic picture changes. Negotiations can even go beyond resolving conflicts for the parties and can extend to making federal policy. ${ }^{28}$

\section{Conclusion}

Galtung's conflict analysis triangle helps separate out the attitudes, behaviors, contradictions/structures and drivers for analysis. Law-related organizations serving the lowincome community in the U.S. should cooperate, increase

28 See, e.g., J. Sunoo, J. Falkner, Regulatory Negotiations: The Native American Experience, [in:] The Consensus Building Handbook: A Comprehensive Guide to Reaching Agreement, eds. L. Susskind, S. McKearnan, J. Thomas-Larmer, 1999. 
incentives for power-sharing, conduct strategic planning, and investigate creative non-legal ways of meeting the legal needs of those who cannot afford a lawyer. Following these recommendations would increase real and perceived access to courts and to dispute resolution, and more low-income people would be helped. The legal field is notoriously slow to adopt technology, but the pandemic has forced lawyers and courts to try some new methods of resolving disputes and new methods of communicating, so this is a time of transformation and change. ${ }^{29}$ The key will be to transform a "vicious conflict circle" into a "virtuous peace circle." ${ }^{30}$

\section{Bibliography}

American Bar Association, A Manual for Legal Services and Pro Bono Mediation Programs, $2^{\text {nd }}$ Edition, 2007.

Dale M., The State of Access to Justice in Oregon, Part 1: Assessment of Legal Needs, March 2000.

Do No Harm Project, Collaborative for Development Action, Inc. and CDA Collaborative Learning Projects, The 'Do No Harm' Framework for Analyzing the Impact of Assistance on Conflict: A Handbook, April 2004.

29 The American Bar Association's Free Legal Answers online legal help platform has expanded during the pandemic, while other pro bono clinics were figuring out how to pivot to remote. This web-based free legal resource, where high-poverty clients ask civil legal questions and volunteer lawyers answer them, makes it convenient for lawyers to volunteer their time and convenient for those in need to ask for legal help. One of the local courts in Indiana has a pilot project where they have installed videoconferencing equipment that unrepresented litigants can come into the courthouse to use, to join online proceedings. Or litigants can join from their phones. It takes less time than having to take time off work and get transportation to the courthouse.

30 B. Holmberg, Rotary Peace Center at Chulalongkorn University presentation, 25 June 2012. 
Fennell M., Ensuring Access to Justice for Self-Represented Litigants, "Judicature", 3.04.2011, Vol. 94.

Fennell M., Using State Legal Needs Studies to Increase Access to Justice for Low-Income Families, "Family Court Review", October 2010, Vol 48.

Galtung J., Violence, Peace and Peace Research, "Journal of Peace Research" 1969, Vol. 6, No. 3.

Genn H., What Is Civil Justice For? Reform ADR and Access to Justice, "Yale Journal of Law \& Humanities" 2012, Vol. 24.

Gideon v. Wainwright, 372 U.S. 335 (1963).

Hawaii Access to Justice Hui, Achieving Access to Justice for Hawai'i's People, November 2007.

Holmberg B., Rotary Peace Center at Chulalongkorn University presentation, 25.07.2012.

Laramore J., The Future of Access to Justice, "Indiana Law Review" 2018, Vol. 51, No. 1.

Legal Services Corporation, The Justice Gap: Measuring the Unmet Civil Legal Needs of Low-Income Americans, 2017.

LSC Survey Finds Major Impact of COVID19 Pandemic on Legal Aid, 24.07.2020, https://www.lsc.gov/media-center/press-releases/2020/lsc-survey-finds-major-impactcovid-19-pandemic-legal-aid.

McBride M., ODR in the Era of COVID-19, "American Bar Association Dispute Resolution Committee", 27.10.2020, https://www.americanbar.org/groups/family_law/committees/alternative-dispute-resolution/odr/.

Molvig D., Bridging the Justice Gap: Gauging the Public's Unmet Civil Legal Needs, "Wisconsin Lawyer", April 2007. Quintanilla V. and R. Thelin, Indiana Civil Legal Needs Study and Legal Aid System Scan, March 2019. 
Resnik J., Fairness in Numbers: A Comment on ATET v. Concepcion, Walmart v. Dukes, and Turner v. Rogers, "Harvard Law Review", 2011, Vol. 125.

Reuben R., ADR and the Rule of Law: Making the Connection, "Dispute Resolution Magazine", Summer 2010.

Shepard R., The Self-Represented Litigant: Implications for the Bench and Bar, "Family Court Review", 09.2010.

Silverman S., Thornton J., Prepare for the Tsunami of Court Cases - It's Coming, 7.08.2020, https://www.law.com/dailybusinessreview/2020/08/07/prepare-for-the-tsunamiof-court-cases-its-coming/.

Sunoo J., Falkner J., Regulatory Negotiations: The Native American Experience, [in:] The Consensus Building Handbook: A Comprehensive Guide to Reaching Agreement, eds.

L. Susskind, S. McKearnan, J. Thomas-Larmer, 1999.

Task Force on Civil Equal Justice Funding, Washington State Supreme Court, The Washington State Civil Legal Needs Study, September 2003.

Taubman D., Has the Time Come to Revise Our Pro Bono

Rules? "Denver Law Review" 2020, Vol. 97.

Turner v. Rogers, 131 S.Ct. 2507 (2011).

U.S. Constitution, Sixth Amendment.

Zorza R., Turner v. Rogers: The Implications for Access to Justice Strategies, "Judicature" 2012, Vol. 95.

\begin{abstract}
There are four main types of delivery models for civil legal assistance for low-income people in the U.S.: legal aid organizations with a staff attorney model, pro bono programs, self-represented litigant initiatives, and alternative dispute resolution programs. These programs often fail to collaborate, resulting in low-income people, who need
\end{abstract}


legal help being bounced from place to place and increasing the time to reach resolution or increasing the number of people who give up on a resolution. A number of access to justice programs are interested in increasing funding for access to justice, and they denigrate other models in order to promote their own. Using Johan Galtung's conflict analysis triangle can help break down the conflict to shed some light on how the conflict in access to justice delivery models can be resolved. Law-related organizations serving the low-income community in the U.S. should cooperate and collaborate, increase incentives for power-sharing, conduct strategic planning, and investigate creative non-legal ways of meeting the legal needs of those who cannot afford a lawyer. Following these recommendations would increase real and perceived access to the courts and to dispute resolution and more low-income people would be helped. The pandemic has forced lawyers and courts to try new methods of resolving disputes and new methods of communicating, so this is a time of transformation and change. Let's transform a vicious conflict circle into a virtuous peace circle.

Keywords: access to justice, pro bono, legal aid, self-represented litigant, conflict resolution 


\section{Helen Tanner}

\section{Director of Helen Tanner Forgiveness Services}

\section{Searching for Peace: Finding Forgiveness}

\section{Introduction}

Armed conflict continues to be a major global problem in the twenty-first century. The price paid by individuals and communities is immeasurable, with the repercussions rippling endlessly into the future. Survivors of violence can suffer trauma on physical, psychological, spiritual and emotional levels affecting their relationships, and tying them to the past atrocity, and to those who have committed the violence. Trauma, coupled with a need for self-protection has often led to revenge attacks, and renewed violence. ${ }^{1}$

This chapter explores the role of forgiveness as a means of creating, and living in peace. A peaceful world will be brought about by peaceful people-through peaceful thoughts, and deeds. Within the peacebuilding arena, we must find ways and means to support individuals, communities and the global human family to reach states of inner peace. From this, we sow the seeds of possibility for profound change in the way we relate, live and work with each other and interact with the living planet.

Forgiveness literally means to "give away". It is a process, a journey, an ancient pathway, an inner pilgrimage of trans-

1 E. Staub, Genocide and Mass Killing: Origins, Prevention, Healing and Reconciliation, "Political Psychology" 2000, Vol. 21, No. 2, p. 370. 
forming pain and suffering, into freedom, peace and love. There have been many interpretations of what forgiveness means in practice, and how it can be achieved.

In the conflict resolution field, forgiveness is strangely absent in programmes and policies despite its profound health and wellbeing benefits, and transformative capabilities. It is discussed in the context of reconciliation, however, it attracts controversy and debate which limits its practice on the ground.

Forgiveness is not usually discussed from the standpoint of its potential to support victims recovery, even though, it is recognised that victims that have not healed from their experiences, can go on to become perpetrators of violence themselves.

This chapter explores forgiveness and its potential role within the peacebuilding arena, and also invites us as peacebuilders to embrace forgiveness as a personal practice enabling us, As Ghandi suggests, to "Be the change we wish to see in the world."

\section{Exploring Forgiveness}

In this first section, we will be defining forgiveness, recognising forgiveness as a process, as a choice, exploring the pressure to forgive or not to forgive, and why people may seek the 'medicine' of forgiveness.

\subsection{Defining Forgiveness}

Forgiveness literally means to 'give away'. There is no agreed definition in the conflict resolution field as to what the 'giv- 
ing away' entails. Enright defines it as 'a willingness to abandon one's right to resentment, negative judgment, and indifferent behaviour toward one who unjustly injured us, while fostering the undeserved qualities of compassion, generosity and even love toward him or her."

As a Creative Psychotherapist, specialising in guiding people through the forgiveness process my working definition is:

Forgiveness is the eventual release of feelings of resentment, rage and the desire for revenge against someone who has harmed you, including yourself, for your own freedom, wellbeing and peace. Forgiveness is a personal choice. Forgiveness is not forgetting, condoning or excusing behaviours. Forgiveness does not mean that you have to reconcile with the other person, nor does it exempt them from justice or legal accountability. It should never be used as an excuse to stay in an abusive situation or as a means of self-harming.

Despite slightly differing definitions, we can discern that forgiveness has 'differing degrees': Forgiveness can range from ceasing to hold anger against a perpetrator through to full reconciliation with that perpetrator. There are many stages in between beginning with internal changes in the victim in terms of feelings, and the letting go of a desire for revenge. The stages progress to where a victim could communicate her change of heart and mind to the 'other', ending

2 R.D. Enright, R.P. Fitzgibbon, R.D. Enright, Helping Clients Forgive; An Empirical Guide for Resolving Anger and Restoring hope, "Washington American Psychological Association" 2000 as cited in A. Allan, M.M. Allan, D. Kaminer, D.J. Stein, Exploration of the Association between Apology and Forgiveness amongst Victims of Human Rights Violations, "Behavioral Sciences and the Law Behav. Sci. Law" 2006, Vol. 24 (87-102), p. 90, www. interscience.wiley.com. 
with behavioural changes involved in the re-establishing of relationship with the perpetrator.

\subsection{Forgiveness as a process}

Simon Wilson was left for dead by a hit and run driver. He sustained injuries leaving him chronically disabled. He says that 'Forgiveness is something you have to do every day and it's something that you have to keep doing because anything can trigger that anger again. ${ }^{3}$ Phyllis Rodriguez whose son was killed in 9/11 began with the thought that she would never forgive her sons killers but as time went on she says «I have come to see forgiveness as more than a word; it's a context, a process.4

\subsection{The Importance of Choice}

One thing that seems to be essential is that the choice to embark on the process of forgiveness has to be that of the victims. Simon Wilson notes that 'One thing I find difficult is that in church I've heard sermons about forgiveness and thought 'Who are you to tell me to forgive?' It can sound so easy but it's the hardest thing in the world.Ultimately forgiveness comes from within. Only I know whether I can forgive or not. ${ }^{\text {"n }}$

3 In 1992, Simon Wilson, was the victim of a hit and run car crash in rural Norfolk which left him chronically disabled. The driver was never caught. Story accessed from 'Stories' documented on the Forgiveness Project Website, www.theforgivenessproject.com [access: 3.07.2010].

4 Quote accessed from 'Stories' documented on the Forgiveness Project Website, www.theforgivenessproject.com [access: 3.07.2010].

5 Story accessed from 'Stories' documented on the Forgiveness Project Website, www.theforgivenessproject.com [access: 3.07.2010]. 


\subsection{Feeling the Pressure}

Interestingly, although some feel pressured to forgive, others feel pressured not to by others in their life; Mary Foley's daughter was murdered at a party in an unprovoked attack. Talking about her own forgiveness process she notes; 'Some people tell me I'm brave and strong, but others don't say much. Although no one has come up to me and said, 'you can't have loved your daughter to forgive her killer', I'm sure that's what they think at times. And I understand that, because some people are disgusted by the very idea of forgiveness. It can seem like an act of betrayal. But, on the contrary, I think it's an act of freedom. ${ }^{6}$

\subsection{Why People Seek Forgiveness}

The truth is, people don't often seek forgiveness. What they are seeking is peace, to be free from the past, and to have hope restored. Forgiveness is more often than not stumbled upon, usually after other methods of healing have been tried, and only yielded partial or short term results.

People may continue their seeking, and end up finding forgiveness as a possible solution for them for a number of reasons:

Probably the most common reason is that the painful emotions and thoughts are too heavy a burden to carry. Feelings of rage, resentment, grief, shame, and guilt use

6 Quote accessed from 'Stories' documented on the Forgiveness Project Website, www.theforgivenessproject.com [access: 3.07.2010]. 
a lot of energy, and can feel distressing, when experienced on a regular basis.

Additionally, it may be because in a struggle to manage their feelings, and thoughts, individuals are expressing themselves in ways which are damaging the relationships with those close to them. This 'spilling out' then leads to feelings of guilt and shame and adds further to weight to the suffering.

Another reason maybe, an acknowledgement that what has happened, is part of a bigger pattern not only in their own lifetime, but perhaps in their ancestral or cultural heritage. For many, the desire to heal, is so that the burden of the past doesn't pass on to future generations.

Another reason may be, that a strategy that has been adopted to cope with the pain and suffering has become a problem in its own right demanding attention. For example, as a way of coping with difficult feelings someone may be drinking more alcohol, eating more, getting into conflicts, or adopting risky behaviours - and these symptomatic behaviours, may then ultimately lead onto the forgiveness journey.

Finally, one may seek forgiveness because of an illness which has manifested. Un-forgiveness has been linked to heart attacks, cardiovascular disease, high blood pressure, decreased lung function, muscle tension, stress, anxiety, depression, weight gain, and cancer.

\subsection{Personal Barriers to people choosing to undertake the Forgiveness journey}

- Even if someone does stumble across forgiveness in their search for inner peace, there may be many per- 
sonal barriers that present themselves before someone embarks upon the journey, and also during the process. Some of these are:

- Fear: Fear of what the journey is going to ask of them, fear of 'meeting the wounded self', and importantly the fear that by taking the journey they will become more vulnerable or exposed to being hurt again.

- Waiting: This could be waiting for an apology, acknowledgement, truth, justice, or simply for the other party to suffer and be punished.

- Pressure: People sometimes feel pressure from family or their community either to forgive or not to forgiveand pressure either way can become a barrier. The victim's inner struggle to fight the desire for revenge can sometimes be exacerbated by those around him, or societies call for revenge making the individual choice to avoid violence more difficult. Andrew Rice's brother was killed in the twin towers in 9/11. In his testimony he describes his forgiveness journey and his decisions to turn away from the path of violence or retribution, but observes with a certain degree of cynicism that 'those people crying loudest for retribution so often seem to be the least affected.7

- Misunderstanding: People may carry misunderstandings and false beliefs about what forgiveness is, and its purpose e.g. a lot of people are confused as to the difference between forgiveness and reconciliation. Another belief that becomes a barrier is that 'the other person doesn't deserve it'.

- Unknown process: A lot of people may like the idea of

7 Quote accessed from 'Stories' documented on the Forgiveness Project Website, www.theforgivenessproject.com [access: 3.07.2010]. 
forgiveness and its benefits but don't know how to do it / or where to even start.

Vengeance through self-sacrifice: A common belief is that as a 'victim' of someone else's actions 'the more I suffer, the more they will suffer.' This can be a form of 'vengeance through self-sacrifice' aimed at punishing the perpetrator as though healing is somehow 'letting the perpetrator off the hook.

\section{The Compelling Case for Forgiveness}

In this section we explore the benefits of forgiveness, drawing on research, and the subjective experiences of those who have forgiven.

\subsection{Health Benefits}

In recent research in the fields of health and psychology, results demonstrate that forgiveness is good for the person forgiving. It promotes psychological and physical health, and can allow victims to move on from trauma. ${ }^{8}$ Physical benefits of forgiveness include lower levels of blood pressure, and heart rate. ${ }^{9}$ This finding could be linked to another one which shows that forgiveness decreases stress, whereas hostility increases stress. ${ }^{10}$ Forgiveness also aids depression,

8 K.A. Lawler, J.W. Younger, R.L. Piferi, E. Billington, R. Jobe, K. Edmondson, W.H. Jones, The Unique Effects of Forgiveness on Health: An Exploration of Pathways, "Journal of Behavioral Medicine", April 2005, Vol. 28, No. 2, p. 158.

9 Ibidem, p. 373

10 Ibidem, p. 387. 
and is being included in treatment programmes for heart disease and cancer. ${ }^{11}$

\subsection{Inner Peace}

People who have forgiven say that they have found a sense of inner peace. In 1997, Natalia Aggiano's mother was murdered by her father. She says; 'I'd already lived most of my life with hatred for my dad. I didn't want it anymore. Forgiving him was such a big release. I'll never forget what he did - but forgiving has brought me peace inside. ${ }^{12}$

\subsection{Freedom}

Rosalyn Boyce, describes her experience of forgiving a man who broke into her home and raped her. 'To me, forgiveness now equated to my own freedom. It meant that I no longer had to feel any attachment to my rapist or the act of rape, and by doing so I could free myself from the crime and move on with my life. Once I chose to perceive forgiveness in these terms a massive burden was lifted..$^{13}$

\subsection{Unlocking the Chain to the Perpetrator}

In a very famous speech Archbishop Desmond Tutu talked about forgiveness as being the key to unlock the chain be-

11 Ibidem, p. 374.

12 Quote accessed from 'Stories' documented on the Forgiveness Project Website, www.theforgivenessproject.com [access: 3.07.2010].

13 Ibidem. 
tween the victim and the perpetrator. He argued that continuing to experience anger and hatred locks you in a state of victimhood, making you almost dependent on the perpetrator' 14

\subsection{Releasing Anger \& Rage}

Anger is a natural stage in any grieving process, but when atrocities are committed deliberately, and several losses encountered, anger and rage are usually acute.

Anne Marie Hagan's father was murdered by his schizophrenic neighbour. She explains that "Filled with sadness and despair, I became completely consumed with anger, bitterness, vengeance, and self-pity. I was absolutely determined that this man would never, ever regain his freedom. The longer he was locked away, the greater the value of my father's life... Finally I was able to let go of all the pain and torment that had held me captive, realising that I'd been my own jailer. My life changed as I began to see the world through new eyes. I felt joy again, the numbness was gone." ${ }^{15}$

\subsection{Releasing the Desire for Revenge}

Forgiveness enables the letting go of the desire for revenge. William Saa, was a victim in the Liberian civil war. He describes himself as reaching a 'crossroads' of choice of how to react to the violence he had witnessed and been on the receiving end of. He describes how difficult it was initially

14 Ibidem.

15 Ibidem. 
not to choose the route of violence and to let go of the desire for revenge. 'At first I was planning to return violence with violence. Later, however, I began the search for the strength and courage to face the past constructively. This is not easy when one is overloaded with ugly memories of what happened. I was struggling with my own trauma arising out of the pain and suffering I had endured during the war. ${ }^{16}$

Despite a compelling research base, and enormous anecdotal evidence of the manifold benefits of applying the healing balm of forgiveness after violence, it's practice, and interventions within the peacbuilding arena are extremely limited. The following sections explores this in more detail.

\section{Forgiveness in Peacebuilding: The Unfulfilled Potential}

There are many ways in which we are stifling the potential and power of forgiveness to bring about peace for individuals and communities. In this section we will be exploring some of the obstacles and barriers in place:

\subsection{Forgive and forget?}

One of the reasons forgiveness is resisted in peacebuildin is because it is associated with forgetting. Forgetting is a controversial topic post-violence. There is fear that if things are forgotten they will be repeated. However, Govier questions

16 W. Saa, Approaches to dealing with trauma caused by war and political repression, "Committee for Conflict Transformation Report", newsletter 18 2002, www.c-r.org/ccts/ccts18/index.htm [access: 3.07.2021]. 
the link between forgiveness and forgetting, arguing that it is utterly implausible to think that the wrongdoing would ever be literally forgotten. ${ }^{17}$

\subsection{Forgiving the unrepentant offender}

Another debate raised, concerns forgiving an unrepentant offender. Some argue that forgiveness should only be 'granted' to an offender who apologises and shows remorse for his acts, and to forgive without this amounts to condoning the acts. Such condonation leaves a person or community open to further abuse and violence.

There are times where forgiveness may be inappropriate or 'offered' too soon which could amount to condoning. ${ }^{18}$ However, 'to forgive an offence is not to imply that it was somehow 'permissible or justified'19 This is supported by the experience of Anne-Marie Hagan whose father was murdered by their schizophrenic neighbour. She points out that "Forgiveness is not permission. It doesn't mean that you agree with what the offender has done, or that they had a right to do what they did." ${ }^{20}$

A further point here, is that if forgiveness were always dependent on the remorse of a perpetrator, that would mean that the victim would remain at the 'whim' of the perpetrator, and may never find release from the atrocities committed, and this in itself could be argued to perpetu-

17 T. Govier, Forgiveness and Revenge, London 2002, p. 60.

18 Ibidem, p. 55.

19 Ibidem.

20 Quote accessed from 'Stories' documented on the Forgiveness Project Website; www.theforgivenessproject.com accessed; 3.07.2010]. 
ate its own power imbalance, re-victimisation, and cause further harm. ${ }^{21}$

\subsection{Some acts are too terrible to forgive}

Particularly in the aftermath of genocide, mass killings, tortures, rapes and attacks on civilians, understandably the abhorrence of the acts draws the argument that some acts are 'too bad' or 'too evil' to forgive; ${ }^{22}$ that somehow to do so would be unethical ${ }^{23}$ or even impossible ${ }^{24}$.

However, victims and theorists get around these arguments for non-forgiveness, by pointing to the possibility of separating the person from the action.'25 Shannon Moroney talks about her forgiveness process; 'What I saw before me was a human being, and I knew that in a different lifecourse, it could have been me on the other side of the glass. I hated his actions, but I could not hate the person. Now I understand that, for me, this was an act of forgiveness. ${ }^{26}$

21 T. Govier, op.cit., p. 63.

22 G. Scarre, After Evil; Responding to Wrongdoing, Aldershot 2004, p. 64 .

23 P. Gobodo-Madikizela, Trauma, forgiveness and the witnessing dance: making public spaces intimate, "Journal of Analytical Psychology" 2008, Vol. 53, pp. 169-188.

24 M. Byrom Hartwell, The Role of forgiveness in reconstructing society after conflict (Document first posted on 3 May 1999), www.jha.ac/ articles/A048.htm [access: July 2010].

25 R. Holloway, On Forgiveness; How can we forgive the unforgivable?, Edinburgh 2002, p. 37.

26 Accessed from 'Stories' documented on the Forgiveness Project Website, www.theforgivenessproject.com [access: 3.07.2010]. 


\subsection{Forgiveness as a virtue}

Another argument opposing forgiveness is that it lies in the realm of the divine, and that those that forgive are extolling 'virtue.. 27 The problem with this argument is that it places forgiveness in a realm that is intimidating to the average person dealing with the experiences of atrocity. Although their subjective experience of forgiveness may have a spiritual quality to it, to suggest the process itself is 'divine' removes possibility, and increases resistance to many people even embarking on the journey for risk of failure, or because the very natural feelings they may encounter on the journey such as hatred, and desire for revenge, may make them feel very 'non-virtuous' and lead them to assume they are not able to forgive.

\subsection{Forgiveness could never be taught}

Linked to the argument of forgiveness as virtue, is that if it is so special then it couldn't possibly be reduced down to a 'skill-set' and be taught. On this theme, Mcknight argues that 'Forgiveness can never be a banal therapeutic procedure. $^{\prime 28}$

However, there are examples of forgiveness being 'taught' in conflict areas, dispelling the myth that it is some kind

27 R. Holloway, op.cit., p. 86.

28 A. Mcknight, Historical Trauma, the Persistence of Memory and the Pedagogical Problems of Forgiveness, "Justice and Peace Educational Studies", 2.10.2004, Vol. 36, pp. 140-158. 
of 'divine intervention' or 'random' event. For example, in Northern Ireland a project has been running teaching people to forgive, after family members had been murdered in political violence. Dr Fred Luskin has been running the project. A research project he ran for one week delivering training to mothers of sons killed showed 'less hurt, depression, stress and anger. They also showed more optimism and forgiveness. ${ }^{29}$ Projects such as this are still relatively rare, but are beginning to make a mark in the field disproving that forgiveness is only for the virtuous, or a random occurrence.

\subsection{We shouldn't put pressure on the victims}

A final argument is that from the 'outside' we have no right to 'pressure' victims into forgiving. ${ }^{30}$ Thus, somehow by mentioning it, or investing in projects, we are pressuring people to 'do it'. An immediate response to this argument is could we ever pressure someone to genuinely forgive who is not ready? Forgiveness cannot be forced or rushed.

On the other side of the coin, where a victim wishes to release himself from the atrocity and the past, arguably, the peacebuilding community has a responsibility to support this process, and invest in it. Victims may indeed need to choose to forgive, but on choosing, peacebuilders can have at their disposal maps and tools to support the journey, and not leave victims to traverse the difficult journey alone.

29 F. Luskin, Forgive for Good: A Proven Prescription for health and happiness, New York 2003.

30 D. Bloomfield, “On Good terms” Clarifying Reconciliation, Bergehof report number 14, 2006, p. 22, www.bergehof-centre.org/uploads/ download/br14e.pdf [access: 3.07.2021]. 
In addition to the debates surrounding forgiveness, it is also limited by the viewpoint that its sole use lies in its capacity to bring about reconciliation.

\subsection{Forgiveness and Reconciliation-a limited viewpoint.}

The conflict resolution (CR) field seeks to transform conflicts through various strategies including Peacekeeping, Peacemaking, and Peacebuilding. ${ }^{31}$ At this time, forgiveness within the conflict resolution field, is associated almost exclusively, within Peacebuilding, and in the context of «relationship building" and reconciliation.

Although, as we shall explore and affirm, forgiveness can support a reconciliation process, it is not its only purpose-and a sole focus onto forgiveness as a stepping stone to reconciliation misses many of its key benefits previously explored i.e. its capacity to bring a state of peace, freedom and a restoration of health to the victim, whether the desire and capacity is there to reconcile or not.

\subsubsection{Reconciliation}

Reconciliation lies at 'the heart of deep peacemaking,',3 yet in a post-violent context, can prove extremely challenging, if not impossible. There is no singular definition of what reconciliation is, but there is general agreement that "there are many

31 J. Galtung, After Violence, reconstruction, Reconciliation, and Resolution Coping with Visible and Invisible effects of war and Violence Ch 1 in M. Abu-Nimer, Reconciliation, Justice and Co-existence; Theory and Practice, United States of America. Lexington Books 2001, p. 19.

32 O. Ramsbotham, T. Woodhouse, H. Miall, Contemporary Conflict Resolution, $2^{\text {rd }}$ ed., Cambridge 2005, p. 231. 
degrees of reconciliation, with different mixes of elements" ${ }^{33}$ which could include a functional living beside a former enemy, perhaps because there is little other practical option, at one end of the scale, and moving through to a reconciliation which would include "forgiveness, mercy, and a shared comprehensive vision, mutual healing or harmony" at the other. ${ }^{34}$

\subsubsection{Forgiveness and Reconciliation as Perfect Partners}

One of the biggest advocates for promoting forgiveness together with reconciliation has been Archbishop Desmond Tutu, famous for his work with the South African Truth and Reconciliation Commission.(TRC) $)^{35}$ Tutu, in talking about South Africa noted that: 'The world had expected that the most ghastly blood bath would overwhelm South Africa... those who for so long had been denied their rights, whose dignity had been trodden underfoot, callously and without compunction, would go on the rampage, unleashing an orgy of revenge and retribution that would devastate their common motherland. Instead there was this remarkable Commission, where people told their heart rending storiesvictims expressing their willingness to forgive, and perpetrators telling their stories of sordid atrocities while also asking for forgiveness from those they had wronged so grievously. ${ }^{36}$

33 L. Kriesberg, Constructive Conflicts; From Escalation to Resolution, $3^{\text {rd }}$ ed., Oxford. 2007, p. 323.

34 D.A. Crocker, Reckoning with Past wrongs; A Normative Framework.2004, http://terpconnect.umd.edu/ dcrocker/Courses/Docs/Reckoning\%20with\%20past\%20wrongs.pdf, pp. 20-21 [access: August 2010].

35 N. Walaza, Insufficient Healing and Reparation, pp. 250-255 in C. Villa-Vicencio, W. Verwoerd, Looking back reaching forward; reflections on the Truth and Reconciliation Commission of South Africa 2000.

36 D. Tutu, No Future Without Forgiveness, London 1999, p. 21. 
Tutu emphasises the importance of the wrongdoer acknowledging and apologising for his actions ${ }^{37}$ and if a perpetrator or victim is no longer alive, that others can apologise and receive forgiveness on their behalf ${ }^{38}$. He puts strong emphasis on a fresh start for all concerned and breaking the chains of the past to make a new future possible. Tutu's linking of forgiveness to reconciliation is heavily influenced in his thinking by 'Ubuntu philosophy' and Christian theology.

Additionally, Lederach firmly places forgiveness in the realm of reconciliation in two ways; The first is that he includes Mercy as one of the four essential elements of reconciliation along with Truth, Justice and Peace ${ }^{39}$. Secondly, he places a huge emphasis on relationships as essential to peacebuilding; "relationship is the basis of both the conflict and its long term solution." ${ }^{40}$ He acknowledges the immense courage it takes for people to reconcile with each-other after violence, where fear is enormous ${ }^{41}$ and the inherent risks they take in turning to face each-other once again where trust was broken to such serious degree. ${ }^{42}$

\subsubsection{Limitation to solely partnering forgiveness with reconciliation}

Although forgiveness has two powerful allies in Tutu and Lederach, and they have both been strong advocates in pro-

37 Ibidem, p. 220.

38 Ibidem, p. 226.

39 J.P. Lederach, Building Peace: Sustainable Reconciliation in Divided Societies, Washington DC 1997, pp. 28-31.

40 Ibidem, p. 26.

41 Idem, The Moral Imagination, The Art and Soul of Building Peace, 2005, p. 63.

42 Ibidem, p. 40. 
moting the benefits of forgiveness, the emphasis onto tying forgiveness to reconciliation has also been problematic and unnecessarily limiting. There are situations where former adversaries may reconcile for practical purposes, but do not forgive, and other circumstances, where a victim may forgive a perpetrator but reconciliation is neither possible nor desirable. ${ }^{43}$ In a war situation specific perpetrators may not be known, or may be dead. Perpetrators may refuse to apologise for what they have done, or be under pressure from their community to not acknowledge their actions, or to view them as self-defence or justified. There are also times where it is too dangerous for victims to reconcile with former adversaries.

These factors have limited the ability for forgiveness and reconciliation to function fully together. In our final section we will be advocating for an expanded view of forgiveness as a healing intervention, and an additional locating of it, beyond reconciliation, into the realm of mental health and psychosocial support. In this way, forgiveness, at the right time, and when chosen, can be utilised to its full potential to assist in sustainable peacebuilding methods, rather than a limited or worse, discarded through misunderstanding, and a limited viewpoint.

\section{Forgiveness: A New Expanded Peace Story}

In this final section we will look at several ways to embrace forgiveness within the peacebuilding arena, in order to harness the benefits the process offers, make sure that those who are seeking her remedy are adequately supported, and

43 P. Strelan, T. Covic, A Review of Forgiveness Process Models and a Coping Framework to guide future research, "Journal of Social and Clinical Psychology” 2006, Vol. 25, No. 10, pp. 1059-1085. 
that we continue to evolve and open up the arena for new voices to be heard.

\subsection{Forgiveness for victims sake}

Despite the success of the Truth and Reconciliation Commission (TRC). There was one important criticism levied at its work: «The process of the TRC was geared towards the promotion of national healing. This process should have started with the healing of individuals. The work of the Trauma Centre for Survivors and Torture with the deponents of the TRC has taught us that it is important that individuals be assisted with their pain. This can have ripple effects on those around them-their families, communities and the nation as a whole. Helping survivors of violence has also taught us that in order for healing to have lasting effects, most of it has to start within.» ${ }^{44}$

As explored earlier in the chapter, forgiveness has the innate capacity to support people in healing layers of pain. However, there are steps to the forgiveness journey, and unless it is understood that each step is important, and there is an 'order' to the journey, the temptation can be to miss out some of the more 'messy' steps, those that require applying self compassion to the wounds of rage, of shame, of hatred, of fear, and rushing ahead to the more 'attractive' and 'overt' stages of relationship building. The observations of the limitations of the relational approach of the TRC, at times at the expense of individual healing, are important, and must not be ignored.

44 N. Walaza, op.cit., p. 251. 


\section{2. 'Unilateral Forgiveness'}

Although some, like Roberts, will argue that 'the teleology of forgiveness is reconciliation' ${ }^{45}$ others like Holmgren have makes a case for 'Unilateral Forgiveness'. Forgiveness is 'unilateral' in the sense that it focuses strictly on the beliefs, feelings, attitudes and decisions of the victim. It does not depend on any particular response on the part of the wrongdoer. ${ }^{26}$ This is important in terms of addressing some of the shortcomings of solely seeing forgiveness as having value to aid reconciliation. Holmgrens identifies five step$\mathrm{s}^{47}$ that a victim should go through in order to satisfy her conditions for unilateral forgiveness; She needs to:

1) Recover self esteem;

2) Recognise the perpetration was wrong and why it was wrong;

3) Acknowledge her feelings;

4) Overcome negative feelings towards the offender because of the offence;

5) Assess the situation as regards any potential future 'relationship' with the perpetrator.

Holmgren clearly states that Unilateral Forgiveness has value in its own right, and need not inevitably end in reconciliation. An end point can be that the victim overcomes

45 R.C. Roberts, Forgivingness, "American philosophical Quarterly" 1995, Vol. 32, pp. 289-306 cited in T. Govier, Forgiveness and Revenge, London 2002, p. 77.

46 M.R. Holmgren, Forgiveness and the intrinsic value of persons “American Philosophical Quarterly", October 1993, Vol 30, No. 4, p. 345.

47 Ibidem, pp. 343-344. 
her feelings of anger and resentment, and finds an inner acceptance of the perpetrator. ${ }^{48}$ Some argue that Unilateral Forgiveness is too self-centred. However, the counter argument is that although reconciliation is not the main focus of this type of forgiveness it is not precluded as a potential outcome. And arguably, it is actually enabled by this process as victims have done much inner work to become more peaceful, thus enabling the possibility for the 'outer work' of reconciliation and relationship building.

\subsection{Forgiveness Models and research}

Profound transformations in relationships, and the observable benefits of forgiveness, have led to a number of research projects, particularly in the field of health and psychology. ${ }^{49}$ In numerous studies forgiveness has been proven to have health benefits, both physical and emotional. Programmes have been developed, following the research, where forgiveness is being used to help people with cancer, depression and heart problems. Other studies have looked into what helps the forgiveness process and what hinders it, for example, the use of apology, and prayer. Also, studies into the effect of gender on forgiveness are being looked into. From these studies various models have been developed..$^{50}$

48 T. Govier, op.cit., p. 64.

49 D. Scobie, G.E.W. Scobie, Damaging Events: The Perceived Need for Forgiveness, "Journal for the Theory of Social Behaviour" 1998, Vol. 28 (41), pp. 373-396.

50 For a summary of models see P. Strelan, T. Covic, A Review of forgiveness process models and a coping framework to guide future research, "Journal of Social and Clinical Psychology" 2006, Vol. 25, No. 10, pp. 1059-1085. 
Perhaps the most commonly referred to model of forgiveness is that of Robert Enright, a Psychologist specialising in forgiveness for the past twenty-five years. He has produced a twenty step model that is outlined in his workbook for people who wish to forgive called; Forgiveness is a choice; a step by step process for resolving anger and restoring hope ${ }^{51}$ Enright and colleagues have also produced a comprehensive guide for clinicians ${ }^{52}$ working with a variety of 'disorders' such as Depression, Anxiety, Substance Abuse, Eating disorders, Bipolar and Personality Disorders, on how to apply forgiveness in these contexts. Another Model developed again in the field of psychology, but also grounded in work done in Northern Ireland is that of the H.E.A.L method developed by Dr Fred Luskin, of Stanford University, and summarised in his work 'Forgive for Good.53

These models could be embraced, and expanded upon by the peacebuilding community, and adapted as support packages for people who wish to forgive, and, as a prequel to reconciliation strategies. Further research would also be needed to make sure that any model adopted is relevant to specific cultures, genders, age groups etc.

51 R.D. Enright, Forgiveness is a choice; a step by step process for resolving anger and restoring hope, Washington APA Life Tools" 2001, p. 78.

52 R.D. Enright, R.P. Fitzgibbons, Helping Clients Forgive; An Empirical Guide for Resolving Anger and Restoring hope, "Washington American Psychological Association" 2000.

53 F. Luskin, Forgive for Good' A Proven Prescription for health and happiness, New York 2002. 


\subsection{Co-locating Forgiveness into Mental Health \& Psychosocial Support}

We have explored above, some of the limitations of solely locating forgiveness with reconciliation, and have noted some of the benefits of forgiveness, and why someone might seek forgiveness. Here we will explore looking at an additional home for Forgiveness within the evolving realm of Mental Health and Psychosocial Support (MHPSS). This would both expand the possibilities for someone to access support to undergo the forgiveness journey, should they wish to, but it also de-stigmatises forgiveness-putting it clearly in the realm of a healing intervention rather than a moralistic one. As with any healing intervention, it is not one that can be applied to everyone, at all times-it has a time and a place. It has to be chosen. But with an adequate assessment procedure in place, it can be 'applied' appropriately, and the healing balm can go to work on the most serious of mental, emotional and spiritual wounds.

Mental Health and Psychosocial Support as a specialism is gaining in understanding and importance in the field of peacebuilding and post-conflict reconstruction. ${ }^{54}$ This is in part due to the increasing recognition of the link between

54 Psychosocial Support is an evolving practice and knowledge base. Since 2007, there are in-depth Guidelines on Mental Health and Psychosocial Support in Emergency Settings produced by the Inter Agency Standing Committee (IASC). IASC is a forum, under the leadership of the 'Emergency Relief Co-ordinator, involving UN and non-UN humanitarian partners, which has co-ordinating, policy development, advocacy, and decision-making functions. It was established in 1992 responding to the UN resolution 46/182 focussed on strengthening humanitarian assistance. 
one's inner world of feelings, thoughts and memories, and one's possible engagement in violent conflict.

As Volf notes 'As victims seek to protect themselves, they are not immune to becoming perpetrators ${ }^{35}$, and so the spiral of violence continues. It is not only victims that need to heal, but also perpetrators, either because of prior victimisation, or due to their own actions, or those of their community weighing upon them. Healing can also be needed for 'wounded' leaders in the conflict. ${ }^{56}$ Not only do conflicts begin because of unhealed trauma but they are also sustained by it. ${ }^{17}$

As Curle points out; 'At the centre of all human conflicts, whatever their cause and whatever the rights and wrongs of any particular case, are our apprehensions, anger, resentment, vanity, hurt pride, insecurity, prejudice, the sense of hopelessness, and above all the blurred understanding and the obscure but potent impact of old pains and fears. ${ }^{58}$ With this in mind, Curle introduces the concept and importance of 'private peacemaking,' which he argues is necessary to tackle the emotions and thoughts, and beliefs that may lead to this inner 'unpeacefulness', and its violent consequences. ${ }^{59}$

55 M. Volf, The End of Memory; remembering Rightly in a Violent World, WmB Eerdmans Publishing Co USA 2006, p. 33; E. Staub, L.A. Pearlman, A. Gubin, H. Athanase, op.cit., p. 302.

56 E. Staub, op.cit., p. 372.

57 Ibidem.

58 A. Curle, Peacemaking-Public and Private pp. 17-29 in T. Woodhouse, Peacemaking in a Troubled World Oxford Berg Publishers Ltd 1991, p. 21.

59 Ibidem, p. 20. 


\subsubsection{Key concepts of Mental Health and Psychosocial Support}

To truly put people at the centre of programming, we need to take into account not only their material and physical wellbeing but also their mental, emotional, and spiritual wellbeing (psycho). We need to take into account not only individuals as though they exist in isolation, but also of people in their social world of family and community (social).

Wellbeing: The IASC, in its introduction to its guidelines on Mental Health and Psychosocial Support in emergency settings notes: 'The Psychological and social impacts of emergencies may be acute in the short term, but they can also undermine the long-term mental health and psychosocial well-being of the affected population. These impacts may threaten peace, human rights and development. One of the priorities in emergencies is thus to protect and improve people's mental health and psychosocial wellbeing. ${ }^{60}$

The wellbeing of individuals, families and communities depend to a large extent on which needs of theirs are being met. Needs include those to promote emotional, mental, cultural, spiritual, social, material and biological wellbeing.

Resilience: When assessing for Mental Health and Psychosocial activities, as well as identifying needs, it is equally important to assess the resources individuals and communities have to cope with the adversity and challenges that they are experiencing. The ability to adapt and cope to stress and adversity is often described as resilience. Many people show

60 IASC Guidelines on Mental Health and Psychosocial Support in Emergency Settings 2007. 
amazing resilience in the face of extreme adversity, but some cope less well.

There are many factors which interplay to determine how someone manages a situation, and many people can be at increased risk during a crisis situation, and require higher levels of support. It is important to note that everybody has some resources that support their own mental health and psychosocial wellbeing. The purpose of Psychosocial Support (PSS) is to build on these resources and not undermine them.

Resources individuals may have could include skills in problem solving, communication skills, practical skills, knowledge, spiritual strength, and physical health. They may also have social support including families, neighbours, colleagues, and friends. They could have economic resources, access to materials, or land, and they may still have access to support groups, or employment opportunities.

It is important to note that supporting people to be resilient is not about saying that what has happened to them is acceptable or that nothing should be done to improve the situation causing distress or adversity. On the contrary, supporting resilience, and all PSS interventions go hand in hand with a number of key principles. The very first of which is to promote human rights and protect people at risk of violations.

Community: The community provides a context, and environment to support individuals and families to function well, and is a foundational resource for a population impacted by violence. In conflict situations people's lives are massively disrupted; normal routines, roles, and support systems are stretched and sometimes break down altogether. Displacement and loss are commonplace, and families are often separated. A knock on effect to this breakdown and displacement is the inability for people to access services, 
including spiritual and cultural practices, which previously may have provided meaning in life as well as an invaluable support mechanism.

Therefore, as with resilience, MHPSS interventions will look to strengthen community ties and not to weaken or undermine them. Involving the community in identifying its needs and resources it has to meet those needs, can lead to far more effective, focused and sustainable programming.

Multi-layered psychosocial support: In conflict situations, people are affected in different ways and require different kinds of supports. All layers of the pyramid (shown below) are important and should ideally be implemented concurrently.

Diagram 1. IASC MHPSS Intervention Pyramid

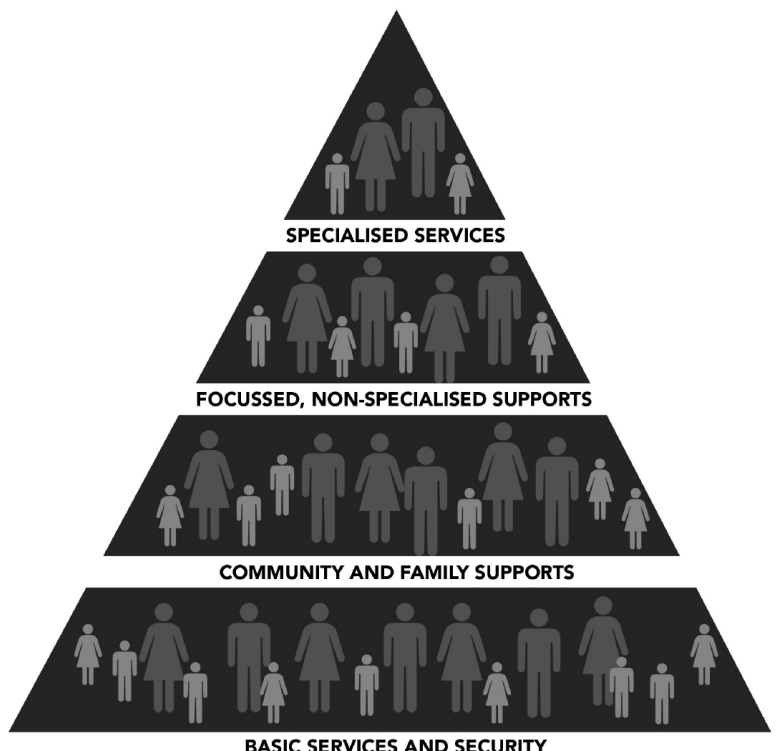

Source: IASC Guidelines on Mental Health and Psychosocial Support in Emergency Settings 2007. 
The triangle illustrates the different level of support that 'affected populations' may require. Embedded is the recognition that promoting people's mental health and psychosocial wellbeing needs to be seen as the responsibility of all humanitarian and peacebuilding actors, not just that of Psychologists, Therapists, or Psychiatrists.

Basic Services and Security; The majority of people can achieve psychosocial wellbeing in time, as long as they can access their basic needs through the provision of services and also connect with family and basic support systems. The large base of the triangle demonstrates this. Activities include; Psychological first aid, supporting safe and equal access to shelter, food, healthcare, sanitation, and water and implementing an MHPSS approach into traditional humanitarian services. Providing Child Friendly Spaces, access to basic education, preventing separation of family members, and sharing essential MHPSS information to affected populations.

Community and family supports; A smaller, but still a significant percentage of the affected population will need support in addition to that offered at level one. This is extra support at the level of community and family. People here may have been adversely affected by family separation, loss, displacement, or a breakdown in community structures. Activities include; engaging and mobilising communities to identify priorities, resources, needs and solutions, to participate in the design and implementation of programmes, utilising community resources, skills and strengths. Providing activities for young people, children, and family re-unification. Providing spaces for social gatherings, peer support, for spiritual communities and traditional coping. Supporting cultural events, exhibitions, and ceremonies. 
Focussed non-specialised support: The third level of support is needed by a smaller number again who in addition to level one and two support require more focused, individual, family or group interventions. These interventions are likely to take place over the medium to long term. Trained and supervised workers usually deliver these. Activities include; helplines, counselling, and focussed support groups e.g for grief, for women, domestic violence, for those who have lost family members etc. Forgiveness support programmes would sit comfortably within level three interventions.

Specialised Services: A minority of the population will need additional specialist psychological or psychiatric supports provided by fully trained and qualified practitioners only. Activities include medical and specialised mental health services.

\subsubsection{Forgiveness as a 'Focussed non-specialised support'}

Forgiveness programmes could be located within level 3 support systems: Focussed and non-specialised support. This would require an appropriate level of training by staff delivering the programmes and also mean that an appropriate needs assessment be carried out. And other interventions would most likely be needed first at levels one, two and four of the intervention triangle. It is important that for forgiveness programmes to be effective and reap the appropriate health and wellbeing benefits that the conditions be conducive and supportive for the interventions.

As with any intervention, but particularly with interventions which focus on supporting mental health and psychosocial support, the timing is important. This is so that the conditions are conducive for the 'healing' to take place. 
Other needs are extremely likely to be prioritised in the short term, and may need to be met before Forgiveness Programmes are offered e.g level 1, 2, or 4 interventions within the MHPSS framework. Examples of these priority needs taking priority before forgiveness work could be the need for safety, protection, basic needs, family support needs, or trauma care. Someone may never wish to forgive, but if they choose this as their path, the peacebuilding community surely has a responsibility to look towards being able to provide the map, tools and guidance as necessary, and not shy away from supporting the healing of someones devastated inner landscape, just as we do not shy away from re-building the physical homes and communities that have been destroyed.

\section{Conclusions}

In this chapter, we have explored what forgiveness is, its benefits and its current location within the arena of peacebuilding, specifically its relationship with reconciliation. We have explored who and what have influenced this partnership, and we have noted some of the limitations of it. We have acknowledged the beliefs, judgments and misunderstandings surrounding forgiveness, which have tended to severely limit the use of forgiveness as a healing mechanism in 'practice'.

We have suggested that it is time for the peacebuilding arena to focus more on the needs for healing of victims of violence. Future violence can be prevented by focussing on victims, as they are supported to resist the urge for vengeance, revenge and for passing on their 'painful' story to fu- 
ture generations. The victim forgiving can also act as a prelude to future reconciliation. Knowledge being accumulated in the field of health and psychology could be translated over to the conflict resolution field, and programmes developed for survivors of violence to be ready to embark on the journey of forgiveness. These could be co-located within the emerging arena of Mental Health and Psychosocial Support.

A change in perception is needed for forgiveness to have a place at the peacebuilding table. At the moment, as demonstrated by the number of debates and controversy surrounding forgiveness, it is not seen as a healing process. It is seen more as a moral process-something that is done to/ or for someone, often who is not deemed to deserve it.

Letting go of pain, suffering, rage can actually be controversial and attract pressure from friends, or others in society who believe that the victim 'should' at least want revenge, even if she does not carry it out. The influence and pressure of others must be noted as important for any programme which may seek to support individuals in their forgiveness process. Education of what forgiveness is and is not would be an essential part of that programme.

As a final note, in addition to what can be done to support those who have experienced directly the devastating repercussions of violence, as Peacebuilders we are also invited to invite forgiveness into our lives. Our own ability to transform our unhealed places, and find peace within us, not only acts as an inspiration to others as we 'walk our talk' but as we are all responsible for creating peace, we are in the em-powered position to not only practice and contribute to peace at the professional level but also at the deeply personal.

May Peace start with me. 


\section{Bibliography}

Allan A., Allan M.M., Kaminer D., Stein D.J., Exploration of the Association between Apology and Forgiveness amongst Victims of Human Rights Violations, "Behavioral Sciences and the Law Behav. Sci. Law" 2006, Vol. 24, www.interscience.wiley.com.

Bloomfield D., "On Good terms"Clarifying Reconciliation, Bergehof report number 14 Found at www.bergehofcentre.org/uploads/download/br14e.pdf.

Botcharova O., Implementation of track two diplomacy: Developing a model of forgiveness. In: Forgiveness and Reconciliation: Religion, Public Policy, and Conflict Transformation, ed. R. Helmick \& R. Petersen. Philadelphia 2001. Byrom Hartwell M., The Role of forgiveness in reconstructing society after conflict www.jha.ac/articles/A048.htm.

Crocker D.A., Reckoning with Past wrongs; A Normative Framework, http://terpconnect.umd.edu/ dcrocker/ Courses/Docs/Reckoning\%20with\%20past \%20wrongs.pdf. Enright R.D., Forgiveness is a choice; a step by step process for resolving anger and restoring hope, Washington 2001. Enright R.D., Fitzgibbons R.P., Helping Clients Forgive; An Empirical Guide for Resolving Anger and Restoring hope, "Washington American Psychological Association" 2000. Enright R.D., Zell R.L., Problems encountered when we forgive one another, "Journal of Psychology \& Christianity" 1989, Vol. 8, No. 1.

Forgiveness Project, www.theforgivenessproject.com.

Galtung J., After Violence, reconstruction, Reconciliation, and Resolution Coping with Visible and Invisible effects of war and Violence, Ch 1 in M. Abu-Nimer, Reconciliation, Justice and Co-existence: Theory and Practice, United States of America. 2001. 
Gobodo-Madikizela P., Trauma, forgiveness and the witnessing dance: making public spaces intimate, "Journal of Analytical Psychology" 2008, Vol. 53.

Govier T., Forgiveness and Revenge, London 2002.

Holloway R., On Forgiveness; How can we forgive the unforgivable?, "Edinburgh Canongate" 2002.

Holmgren M.R., Forgiveness and the intrinsic value of persons, "American Philosophical Quarterly", October 1993, Vol. 30, No. 4.

IASC Guidelines on Mental Health and Psychosocial Support in Emergency Settings 2007.

Kriesberg L., Constructive Conflicts; From Escalation to Resolution, $3^{\text {rd }}$ ed, Oxford 2007.

Lawler K.A., Younger J.W, Piferi R.L., Billington E., Jobe R., Edmondson K., Jones W.H., The Unique Effects of Forgiveness on Health: An Exploration of Pathways, "Journal of Behavioral Medicine”, April 2005, Vol. 28, No. 2.

Lederach J.P., Building Peace: Sustainable Reconciliation in Divided Societies, Washington DC 1997.

Lederach J.P., The Moral Imagination: The Art and Soul of Building Peace, 2005.

Love M., Peacebuilding Through Reconciliation in Northern Ireland, Aldershot, Avebury 1995.

Luskin F., Forgive for Good; A Proven Prescription for health and happiness New York 2003.

Mcknight A., Historical Trauma, the Persistence of Memory and the Pedagogical Problems of Forgiveness, Justice and Peace, "Educational Studies", October 2004, Vol. 36, Issue 2. Ramsbotham O., Woodhouse T., Miall H., Contemporary Conflict Resolution, $2^{\text {nd }}$ ed 2005.

Roberts R.C., Forgivingness, "American philosophical Qaurterly" 1995, Vol. 32. 
Saa W., Approaches to dealing with trauma caused by war and political repression, Committee for Conflict Transformation Report, newsletter 18 2002, www.c-r.org/ccts/ ccts18/index.htm.

Scarre G., After Evil: Responding to Wrongdoing, Aldershot 2004.

Staub E., Genocide and Mass Killing: Origins, Prevention, Healing and Reconciliation, "Political Psychology" 2000, Vol. 21, No. 2.

Staub E., Pearlman L.A., Gubin A., Athanase H., Healing, Reconciliation, Forgiving and the prevention of violence after genocide or mass killing: an intervention and its experimental evaluation in Rwanda, "Journal of Social and Clinical Psychology” 2005, Vol. 24, No. 3.

Strelan P., Covic T., A Review of forgiveness process models and a coping framework to guide future research, "Journal of Social and Clinical Psychology" 2006, Vol. 25, No. 10. Tutu D., No Future Without Forgiveness, London 1999.

Walaza N., Insufficient Healing and Reparation, pp. 250-255 in C. Villa-Vicencio, W. Verwoerd, Commission of South Africa Cape Town 2000.

Wangh S., Revenge and Forgiveness in Laramie, Wyoming, "Psychoanalytic Dialogues" 2005, Vol. 15 (1).

\begin{abstract}
This chapter explores the role of forgiveness as a means of creating, and living in peace. A peaceful world will be brought about by peaceful people-through peaceful thoughts, and deeds. Within the peacebuilding arena, we must find, ways and means to support individuals, communities and the global human family to reach states of inner peace. From this, we sow the seeds of possibility for profound
\end{abstract}


change in the way we relate, live and work with each other and interact with the living planet. Forgiveness literally means to 'give away'. It is a process, a journey, an ancient pathway, an inner pilgrimage of transforming pain and suffering, into freedom, peace and love. There have been many interpretations of what forgiveness means in practice, and how it can be achieved. In the conflict resolution field, forgiveness is strangely absent in programmes and policies despite its profound health and wellbeing benefits, and transformative capabilities. It is discussed in the context of reconciliation, however, it attracts controversy and debate which limits its practice on the ground. Forgiveness is not usually discussed from the standpoint of its potential to support victims recovery, even though, it is recognised that victims that have not healed from their experiences, can go on to become perpetrators of violence themselves.This chapter explores forgiveness and its potential role within the peacebuilding arena, and also invites us as peacebuilders to embrace forgiveness as a personal practice enabling us, As Ghandi suggests, to 'Be the change we wish to see in the world.'

Keywords: Forgiveness, Reconciliation, Peace, Wellbeing. Peacebuilding 


\section{Sudarat Tuntivivat \\ Assistant Professor at Behavioral Science Research Institute, Srinakharinwirot University, Thailand}

\section{Vocational Education for Sustainable Peace in Southern Thailand}

\section{Vocational Education for Sustainable Peace in Southern Thailand}

Vocational education is an indispensable part of the educational system, being vital for socioeconomic development and sustainable peace. It has traditionally promoted practical and employable skills geared to equip and empower the underserved majority. The former target groups are vulnerable people with limited access to formal education and those who have been marginalized or reemployed back into the workforce (Colley, James, Diment \& Tedder, 2003; ${ }^{1}$ Hoeckel, $2008^{2}$ ). The contemporary vocational education system attempts to prepare youth with job-related skills and to interact with the apprenticeship system linked with current local, national, and global labor markets (Abassah, ${ }^{3}$ 2011; Friberg,

1 H. Colley, D. James, K. Diment, M. Tedder, Learning as becoming in vocational education: class, gender and the role of vocational habitus. Journal of Vocational education 2003, No. 4, pp. 471-498.

2 K. Hoeckel, Costs and Benefits in Vocational education, OECD office, http://www.oecd.org/education/innovationeducation/41538706. pdf [access: 29.12.2015].

3 M. Abassah, Analysis of the Problems and Prospect of the Technical 
$\left.2014^{4}\right)$. The expansion of vocational education from vulnerable and marginalized groups included the majority of the population, especially members of the younger generation can be a coping mechanism for the current mismatching of skill in the local, national, and global labor markets (European Union, 2011; $;^{5}$ Eichhorst et. al., 2012; ${ }^{6}$ United Nations, 2013; Dahil, Karabulut, \& Tahta, 2013 ${ }^{8}$ ).

The economic development of the Thai society fundamentally depends on the strength of vocational education to improve the skills and knowledge of young people so that they have access to the labor market and be able to obtain stable careers and higher income occupations (United Nations, 2013). Nonetheless, the overwhelming majority of Thai students have limited interest in vocational education, so they are unskilled and unprepared for the world of work. The ten-

College Teachers in Nigeria, Semantic scholar, http://www.hrmars.com/ admin/pics/181.pdf [access: 8.10.2015].

4 K. Friberg, Apprenticeship orientation as planned behavior in educational choices: A path model of antecedent beliefs. Empirical Research in Vocational Training 2014. No. 7, https://doi.org/10.1186/s40461-0140007-z [access: 8.10.2015].

5 European Union, The Benefits of Vocational education. European Centre for the Development of Vocational Training. http://www.cedefop. europa.eu/EN/Files/5510_en.pdf [access: 29.12.2015].

6 W. Eichhorst, N. Rodríguez-Planas, R. Schmidl, K. Zimmermann, A Roadmap to Vocational education Systems around the World, IZA, http://ftp.iza.org/dp7110.pdf [access: 29.12.2014].

7 United Nations, A New Global Partnership: Eradicate Poverty and Transform Economies Through Sustainable Development. The Report of the High-Level Panel of Eminent Persons on the Post-2015 Development Agenda, Division for Sustainable Development Goals, https:// sustainabledevelopment.un.org/index.php? page $=$ view \& type $=400 \& n-$ $\mathrm{r}=893 \&$ menu $=35$ [access: 19.08.2015].

8 L. Dahil, A. Karabulut, F. Tahta, Problems Encountered in Educating Qualified Workforce in Vocational High Schools and Solution Seeking, "The Online Journal of Quality in Higher Education” 2013, No. 2, pp. 45-52. 
dency of low education attainment in vocational education can be mainly explained by negative images, social norms, and stigmas related to vocational education (Wonacott, 2000; ${ }^{9}$ Alessandri, 2001; ${ }^{10}$ Amedorme, \& Fiagbe, $\left.2013^{11}\right)$. Moreover, the public often perceive vocational students as second-class citizens who tend to have lower academic achievements, demonstrate violent behavior and are more likely to end up working blue collar jobs that are dirty, dangerous, and demanding after graduation (Pimpa, \& Suwannapirom, 2007;12 Suthieat, $2008{ }^{13}$ Wisetsri, $\left.2011^{14}\right)$. As a result, Thai students either pursue education in the general stream or just drop out of school since they do not see the benefit of vocational education.

Consequently, there is a labor force of 35-40 million people who lack skill development due to the fact that $70 \%$

9 M. Wonacott, Vocational Education Myths and Realities. The ERIC Clearinghouse on Adult, Career, \& Vocational Education Myths and Realities Series: Benefits of Vocational Education. Raising Special Kids, http://www.raisingspecialkids.org/_media/uploaded/j/0e1833985_jobvocationaleducationmythsandrealities.pdf [access: 31.12. 2015].

10 S. Alessandri, Modelling corporate identity: a concept explication and theoretical explanation, "Communications: An International Journal" 2001, No. 4, pp. 173-182, https://doi.org/10.1108/EUM0000000006146 [access: 8.10.2015].

11 S. Amedorme, A. Yesuenyeagbe, Challenges Facing Technical and Vocational Education in Ghana, "International Journal of Scientific \& Technology Research" 2013, No. 6.

12 N. Pimpa, S. Suwannapirom, (2007), Thai students' choices of vocational education: marketing factors and reference group. Springer Science+Business Media. Educational Research for Policy and Practice" 2008, No. 7, pp. 99-107.

13 T. Suthieat, Attitudes toward conflict behavior of vocational students (Unpublished master's thesis), Thammasat University, http://tdc. thailis.or.th/tdc/basic.php [access: 1.05.2015].

14 P. Wisetsri, Conflict between vocational students from different institutions (Unpublished master's thesis). Kasetsart University, http://tdc. thailis.or.th/tdc/basic.php [access: 1.05.2015]. 
of students drop out of secondary education and about 2.5 million students in higher education, while slightly over 1.1 million students were enrolled in vocational education in Thailand (Office of the Minister, 2014). The rising number of mismatched skills in the workforce is the root cause of the supply and demand of manpower in Thailand. Therefore, the development of effective vocational education is vital for promoting practical skills and the necessary knowledge for educating and transforming young people to be good, productive Thai citizens (UNESCO, 2014 $4^{15}$ ). It also an effective tool to reduce crime, prostitution, terrorism, insecurity and conflict (Joseph, Utin, Akpan and Usoro, $\left.2013^{16}\right)$.

The Ministry of Education recognized the importance of vocational education, so they established a blueprint to increase the ratio of vocational to general academic track at the secondary education level from the current proportion, which is 40:60, to 60:40 over the next 10 years. The main goal is to produce enough graduates with technical skills and knowledge to serve the demand of the current global and national labor market (Office of the Minister, 2014). Moreover, this new education reform highlights the importance of vocational education in diverse areas of the country. It launched a policy intervention called area-based education, which puts emphasis on the development of occupational competencies and practical skills necessary for

15 UNESCO, Education for Peace and Sustainable Development. Concepts, Clarity and Cohesion. A Set of Papers Commissioned by MGIEP, UNESCO, https://in.one.un.org/wp-content/uploads/2016/09/227521e. pdf [access: 19.08.2015].

16 E. Joseph, A. Utin, G. Akpan, H. Usoro, Functional technical and vocational education for values, knowledge, skills and national development, "Journal of Pristine" 2013, No. 1, pp. 1-10. 
employment in the local labor market (Ministry of Education, $2015^{17}$ ). This policy reform also aims to tackle socioeconomic and demographic diversity in order to eradicate poverty and reduce social inequality among marginalized groups. Subsequently, vocational education has been used as a means to promote employable skills geared towards livelihood development as a key element in improving quality of life and not only young people, but other target groups such as women, people with disabilities, minorities, and other socially vulnerable people in rural and marginalized areas around Thailand.

Nonetheless, the enrollment rate in vocational education remains awfully low in some target areas, such as the special development zone of the southern border provinces of Thailand: Yala, Pattani, Narathiwas, Satun, and some parts of Songkhla. When I took a closer look at these target areas, the proportion of students in the general stream, compared to the vocational stream remains shockingly low at 94: 6 in the special development zone and amidst armed conflict in the southern border provinces (Office of the Minister, 2014). The recent survey on the level of education of workers in the special development zone of southern border provinces found that most workers are uneducated and have less than a lower level of secondary education (Vocational Education Commission, 2012). There are a few workers with vocational degrees that were necessary in the local market. In Yala Province, there are only 5,647 vocational workers or about $2.17 \%$. Similarly, there are 4,975 vocational workers or $1.14 \%$

17 Ministry of Education, President of the Southern Border Teachers' Union supports the work of the Minister of Education, Office of the Minister Newline, http://www.moe.go.th/websm/2015/apr/116.html [access date: 22.07.2015]. 
in Pattani Province and about5,370 vocational workers or $1.45 \%$ Narathiwat Province. In Songkhla province, the number is a little higher at 39,651 vocational workers; however, it is only about $4.90 \%$. There are 3, 535 vocational workers or $2.13 \%$ in Satun Province (Vocational Education Commission, 2012).

I conducted initial interviews and found that many of the vocational education students in the region are low-income, underprivileged, and ethnic minority students who have been affected by the intermittent armed conflict. However, this negative image on vocational education was far lower in the minds of students, parents, teachers, principals, and administrators. On the contrary, many of the interviewers, especially the Thai - Malay Muslims, who were profoundly affected by the armed conflict, vigorously maintain the positive advantages of vocational education, such as free education, the ability to learn practical skills and earn income during their school years, and guaranteed employment after graduation. It is contentious to me that low enrollment in vocational education cannot be explained simply by its negative image and the social stigma in the context of this research due to its complexity, diversity, and instability amidst armed conflict.

The research on vocational education for sustainable peace is indeed multifaceted and complicated and often involves both the psychological construction of the individual and social changes (Yasin, Nur, Amin, Ridzwan, Ashikin and Bekri, 2013 $\left.{ }^{18}\right)$. However, the literature tends to focus on one specific discipline, either micro-psychology constructs or

18 R.M. Yasin, Y.F.A. Nur, C.R. Ridzwan, H.T. Ashikin, R.M. Bekri, Current Trends in Technical and Vocational Education Research: A Meta-Analysis, "Asian Social Science” 2013, No. 13, pp. 243-251. 
macro-sociology standpoints. The micro-psychosocial research tended to examine a current state of vocational education in Thailand from the violent behavior of vocational students (Suthieat, 2008; ${ }^{19}$ Wisetsri, 2011 ${ }^{20}$ ) and the negative image and perception of vocational education from the public (Bureau of Vocational Education Research and Development, 2015 ${ }^{21}$ ). In turn, the macro-socioeconomic research explored the dropout problems of students in vocational education (Vocational Education Commission, 2014) and the return on investment of vocational education (Moenjak \& Worswick, 2003 22 ). Moreover, the research on peace education in southern Thailand normally emphasized Islamic education (Liow, 200923; Fahrungsang, 2012) and educational reform (Liow, 2010; Nitjarunkul, Sungtong, \& Placier, $\left.2014^{24}\right)$ However, there is limited research investigating the insights of multiple perspectives at the macro, meso, and

19 Suthieat, T. Attitudes toward conflict behavior of vocational students (Unpublished master's thesis). Thammasat University, http://tdc. thailis.or.th/tdc/basic.php [access: 1.05.2015].

20 Wisetsri, P. Conflict between vocational students from different institutions (Unpublished master's thesis). Kasetsart University, http://tdc. thailis.or.th/tdc/basic.php [access: 1.05.2015].

21 Bureau of Vocational Education Research and Development, Executive summary: The decision to pursue a vocational education Office of the Vocational Education Commission, http://ver.vec.go.th/Portals/11/ download/Filedowloand/summary_1.pdf [access: 5.11.2015].

22 T. Moenjak, C. Worswick, Vocational Education in Thailand: A Study of Choice and Returns, "Economics of Education Review" 2003, No. 1, p. 99-107.

23 J. Liow, Religious Education and Reformist Islam in Thailand's Southern Border Provinces: The Roles of Haji Sulong Abdul Kadir and Ismail Lufti Japakiya, "Journal of Islamic Studies" 2010, No. 1, pp. 29-58. https://doi.org/10.1093/jis/etp026 [access: 5.11.2015].

24 K. Nitjarunkul, E. Sungtong, P. Placier, Challenges of Educators in the Context of Education Reform and Unrest: A Study of Southern Border Provinces in Thailand, "Asian Social Science" 2014, No. 18, pp. 232-239. 
micro levels of vocational education for sustainable peace in southern Thailand.

Hence, the purpose of this research is to investigate how students, teachers, principals, and administrators identify underlying conditions influencing students' decisions to pursue vocational education for sustainable peace in the Special Development Zone and amidst armed conflict in southern Thailand. This paper began with a literature review on the specific historical context of education in the Special Development Zone and under threat of armed conflict in southern Thailand.

\section{Historical Context and Education System}

The Special Development Zone of Southern Border Provinces consists of five provinces: Satun, Yala, Pattani, Narathiwat, and four districts in the upper southern province of Songkhla, where $80 \%$ of the population are ethnic Thai-Malay Muslims who make up close to five percent (two million people) of the entire population of Thailand. Within this context, there are two distinct situations, in the Satun province, the majority of ethnic Thai - Malay Muslims speak fluent Thai and have remained peaceful because they can integrate themselves into mainstream Thai culture. On the contrary, the Malay-speaking provinces of Pattani, Narathiwat and Yala and some parts of Songkhla are more inclined to separatism and have been plagued by violence since 2004 .

Historical diversity and politics have led to various tensions between the government and separatists in the region for many decades. The public schools are used as vehicles to advocate a homogeneous cultural identity and the Thai Cul- 
ture mandate prohibiting Islamic education created a great deal of resentment (Engvall \& Anderson, 201425; Funston, 2010 26 ; Joll, 2015 27 ; Yusef, 200728; Melvin, 200729). The recent education reforms have modified the educational system and tailored more modern curricula to fit with local cultural norms (National Education Act, 1999). Therefore, the compulsory education system, especially at the secondary level, is quite different than that in the rest of Thailand because it has been divided into three categories: (1) public schools; (2) private Islamic school teaching combining secular and religious education; and (3) pondoks teaching religious education only.

Since the violence erupted in 2004, the insurgents have targeted and attacked public schools; one in three public schools have been burned down by insurgent groups. Pattani province has the highest number of incidents, with 130 schools burned down, followed by 83 schools in Narathiwat province, 81 schools in the Yala province and 17 schools in the four districts of Songkhla province (Ministry of Education, $2015^{30}$ ). Therefore, private Islamic schools have be-

25 A. Engvall, M. Andersson, The dynamics of conflict in southern Thailand, "Asian Economic Papers" 2014, No. 13, pp. 169-189.

26 J. Funston, Malaysia and Thailand's Southern Conflict: Reconciling Security and Ethnicity, "Contemporary Southeast Asia" 2010, No. 2, pp. 234-235.

27 C. Joll, Religion and Conflict in Southern Thailand: Beyond Rounding Up the Usual Suspects, "Contemporary Southeast Asia" 2010, No. 2, pp. 258-279.

28 I. Yusef, The Southern Thailand Conflict and the Muslim World, "Journal of Muslim Minority Affairs" 2007, No. 2, pp. 319-339.

29 N. Melvin, Conflict in Southern Thailand: Islamism. Violence and the State in the Patani Insurgency, SIPRI Policy Paper No. 20. September, Bromma 2007.

30 Ministry of Education, President of the Southern Border Teachers' 
come increasingly popular in the Thai-Malay Muslim community, leading to the declining enrollment of students in public schools and pondoks, with some estimates as high as $85 \%$ enrollment in private Islamic schools (Liow, 2009 ${ }^{31}$ ). However, vocational education remains out of the favor of the local community.

Vocational education has been one of the main driving educational policies to tackle socioeconomic and demographic diversity with the purpose of eradicating poverty and reducing social inequality among marginalized groups in the conflict region (Bureau of Vocational Education Research and Development, 2015; ${ }^{32}$ Office of the Education Council, 2016). 18 vocational education institutes in the Special Administrative Development Zone in the Southern Border Provinces play a significant role in driving policies advocating vocational educational management through royal guidance strategies, such as "understanding, approaching, and developing" or putting a "sufficiency economy approach" into practice with the principles of formal education, non-formal education and dual vocational training systems, as well as following the four main strategies of expanding vocational education opportunities; creating jobs and development in a peaceful society; developing quality

Union supports the work of the Minister of Education, Office of the Minister Newline, http://www.moe.go.th/websm/2015/apr/116.html [access: 22.07.2015].

31 J. Liow, Religious Education and Reformist Islam in Thailand's Southern Border Provinces: The Roles of Haji Sulong Abdul Kadir and Ismail Lufti Japakiya, "Journal of Islamic Studies" 2010, No. 1, pp. 29-58. https://doi.org/10.1093/jis/etp026 [access: 5.11.2015].

32 Bureau of Vocational Education Research and Development, Executive summary: The decision to pursue a vocational education Office of the Vocational Education Commission, http://ver.vec.go.th/Portals/11/ download/Filedowloand/summary_1.pdf [access: 5.11.2015]. 
vocational education; and increasing the potential of colleges and security (Phuangchan, Sungtong, Vanitsuppavong, and Choosuwan, 2015 $5^{33}$ ). Despite various strategies to improve vocational education in the target areas, the number of vocational students remained low with 94:6 ratios between the general and vocational streams (Vocational Education Commission, 2014).

\section{Research Methods}

This qualitative case study took place in the five provinces of the Special Development Zone in Southern Thailand, consisting of Satun, Yala, Pattani, Narathiwat, and four districts in the upper southern province of Songkhla. As an outsider to the cultures examined in the study, I reviewed documents, conducted school site observations, developed rapport with the participants through face-to-face interviews and focus groups with 31 key informants, including students, parents, teachers, guidance counsellors, and principals from six out of eighteen vocational colleges across the region. These key respondents were purposely selected. The ethical approval for this research was granted by the Institutional Review Board (IRB) of Srinakharinwirot University, in accordance with the declaration of Helsinki regarding the ethical principles for research with human subjects (Certificate of approval no SWUEC/E-105/2559). Furthermore, a written informed consent was also obtained prior to the

33 S. Phuangchan, E. Sungtong, P. Vanitsuppavong, R. Choosuwan, Management of Vocational Education Development of Special Administrative Development Zone in Southern Border Provinces, "Academic Services Journal Prince of Songkla University” 2015, No. 2, pp. 122-130. 
interviews, which lasted from fifty minutes to three hours. All the interviews and focus groups were audio recorded and transcribed verbatim with separate files for each case. The content analysis was used to analyze both the interviews and focus group discussions. The data triangulation methods used evidence from different types of data sources, such as primary and secondary research, including conversational interviews, structured-question interviews, focus group discussions, documents, public records, pictures, and observations from across five provinces of the Special Development Zone in Southern Thailand.

\section{Case 1: Ethno-Religious Conflict in the Three Southern Border Provinces and Four Districts of Songkhla}

The separatist insurgents attacking civilians and targeting public school teachers resulted in more people migrating outside the three southern border provinces. Especially, the Thai Buddhists working temporarily in the region were more likely to transfer to different locations due to the fear of insurgent attacks. On the other hand, Thai-Malay Muslims who had lived in the three southern border provinces for many decades were less likely to migrate. Many Malay Muslim students from vocational schools claimed they have no intention to migrate because they feel that the insurgency is normal and not a problem for them. As one student from technical college claimed "I will not move out of the region, because I am born and raised in Pattani. My family is in Pattani; even if I get a job outside, I still want to reside in Pattani." A Thai-Malay Muslim teacher from vocational college added: "The conflict always occurs, but the changes 
are less severe for Thai Buddhists because, they relocate out of the region due to fear of the insurgency, but for me, this is my hometown, so I want to die here." Since the violence erupted, the number of Thai Buddhist children are gradually declining because Thai Buddhist parents prefer to send their children to study outside the region.

Therefore, the overwhelming majority of students in the three Southern border provinces are ethnic Thai-Malay Muslims, who tend to value religious education over secular or vocational education. As one female Buddhist public educational specialist claimed: "There was a public policy to register private Islamic schools teaching combined lessons of Islamic principles and public curriculum. Hence, ThaiMalay Muslim parents transferred their children to these schools because they preferred religious education for their children." Unfortunately, many private Islamic schools are registered with the government to receive financial support, but do not adhere to the regulations, resulting in a poor academic performance among Thai-Malay Muslim students in comparison to both the national standard and other public schools in the region.

\section{Public Policy Intervention}

The policy of the government requires vocational schools across Thailand, especially in the Special Development Zone in Southern Thailand, to increase the number of students. The aim of the recent education policy, the implementation of a dual vocational education and training program combined apprenticeships in a company and vocational education at vocational schools in one course has 
been to attract more students. One male Thai Buddhist teacher backed this up when he said the following: "There is a vocational policy to increase the number of students, so we modify the curriculum for vocational qualifications. We establish a dual-education training program with a bilateral agreement and MOUs with business owners so that our students can learn at school and in the factory. The bilateral system is a 50:50 ratio, which means two years vocational of the qualification program. Students study at school for one year and then another year in the factory". Furthermore, the vocational schools in the Special Development Zone in Southern Thailand attempted to rebrand vocational education through school outreach and social activities. As a male Thai Buddhist principal explained: "We always organize social activities and outreach projects to promote our image to the local people. For example, we established a "Fix It Center" which is a free service for engine and oil changes as well as the general inspection of a car before people travel during the New Year and Thai New Year. This program received much appreciation from the local people and the community."

Many students claimed they repeatedly received positive information from the Thai government, such as the idea that vocational workers are a key driving force of the national economy, so they were much more confident about the vocational education and their own future. This is especially true of the vocational institutes in the three Southern border provinces which have slogans to promote ethnic Thai-Malay students to attend vocational education called "Vocational Education for this Life and the Next Life". A male Thai-Malay Muslim student claimed: "To take part in vocational education is not to change religion. We must 
change the misconception and understand that for us to live in the next life that we must survive this life. We have to think of what we will be doing this life as well as the next life; therefore, getting vocational education to earn income is necessary to live comfortably in this life and make some merit for the next life".

Moreover, vocational schools have tried to reach out to students from both public and private Islamic schools. The road shows are a typical public relations activity in which local teachers and students can access to knowledge about vocational education. As a female Thai Buddhist principal mentioned: "We organized the roadshows to all types of schools in the region in response to the latest government policy which aims to provide opportunities to access vocational education." Another male Thai Buddhist principal elaborated on his challenging experiences on outreach students from private Islamic schools: "My activity is to work with outreach students from religious schools. I began to work with 30 private Islamic schools. Generally, the religious teachers and leaders did not support their students to study in vocational schools. They want to keep their students or are more likely to support studies at university than vocational school. Nonetheless, there are some students who would like to study in a vocational school for the following reasons: (1) vocational education only takes two years with a guaranteed job, while university takes four years to get a degree and it is more difficult to find a job because they have knowledge, but no skills; (2) vocational education is inexpensive; and (3) students can work to earn income during their school years." 


\section{Expectations and the Choices of Students}

This study found that students who choose vocational education are confident, interested in the subjects that they are studying and are more likely to see the value of vocational education. As one female Thai-Malay Muslim student claimed "My father died from an insurgent attack, so my mother receives approximately 4,500-Baht compensation money per month. I decided to study in vocational school because it is not very expensive. Moreover, I can take some student loans and work during my school years and learn practical skills from vocational college". Moreover, many students claimed they wanted to study in vocational or technical schools because they were interested in learning, earning income during their school years and having a good career in the future. As one female Thai-Malay Muslim student mentioned: "My expectation from vocational education is to get a paid internship and an opportunity to work and to earn some money. Some companies prefer vocational students because vocational students have practical skills rather than just learning about the theory"

Some students claimed they were happier and preferred the focus on practical training and skills in a vocational school rather than learning theory in a secondary school. Moreover, the students believed that vocational study could fulfil their dreams of having their own careers that fit with their educational level. One mechanical student mentioned that he wanted to open a car repair shop in his village because he likes driving and doing engine repairs: "Technical education fits with my interests and talents since I have 
always wanted to be a mechanic and I would like to repair cars. There is no mechanic in my village, so nobody can repair a car. If a car breaks down, they must go to the city. Hence, I can use my technical skill sto work in the villages".

In addition, another student claimed that he decided to attend a vocational school because he can also use the skills acquired there to work part-time and earn some money. "I study vocational education, so I don't have to rely on my parents for money. I can support myself throughout a semester because there are no tuition fees, and I can also work. I am proud to study in a technical school because I can work to earn my own income "

\section{Case 2: Satun Province}

\section{Social Environment}

Satun is another province in Thailand with a majority of ethnic Thai-Malay Muslims. The main distinction between Satun and the three southern border provinces is that the Thai - Malay Muslims in Satun are more secular and use the Thai language to communicate. Moreover, Satun was not affected by the armed conflict. Therefore, the current dynamics and situation regarding education in the Satun province is different from the three southern border provinces and four districts in Songkhla. Nevertheless, the social environment of the local communities influenced the learning behavior of students. As one male Thai Buddhist teacher explained: "Satun is a small province. Most people work in agriculture and in the fishing sector. Most people with their own businesses normally send their children to public 
schools. However, people who work in agriculture and in the fishing sector normally send their children to vocational schools because they are cheaper than public schools". Since there are not many distinctions between Thai-Malay Muslims or Thai Buddhists because Muslims in the Satun provinces are much more secular and non-traditional, they are less likely to focus on religious study and care about their future careers. As one male teacher at the technical college claimed: "The mindset of the parents here is different to the three Southern border provinces. Since Thai-Malay Muslim parents in Satun are more modern and secular, they are not so focused on religious study and want their children to get a good job after graduation." My study found that the policy on the registration of pondoks or private Islamic schools have increased the number of pondoks in Satun since it has an $80 \%$ Muslim population. However, the increase in the number of pondoks is not as drastic as in the three southern border provinces, because the majority of Thai-Malay Muslims were more secular. As one male teacher technical college added: "In the past, there were approximately three Islamic schools, but currently there are more than ten schools".

\section{Public Policy Intervention}

The free education policy is another underlying condition influencing students to attend vocational schools. In particularly, families experiencing financial difficulty can consult with schools or talk to teachers in the school outreach program. The image of vocational schools is quite positive among both parents and children in the Satun community 
because the government maintains a public relations campaign on the importance of vocational education. This can be used to change the perception of the people. "The government uses public relations to improve the image of vocational schools, which is quite positive among parents and children in the community."

However, the recent government policy on expanding opportunities in education, which attempted to increase the numbers of vocational colleges in rural areas by establishing vocational schools in every provincial and municipal district, greatly decreased the number of students in Satun. As one principal mentioned: "In the past, most of our students were mainly from rural areas outside Satun. We only have $40 \%$ local students but when the government extended educational opportunities, the numbers of students reduced rapidly." In addition, expanding opportunities in the education policy have an impact on the quality of education. As one guidance counsellor claimed: "The policy of expanding opportunities is the opposite of quality because there is no quality".

\section{Choices and Expectations of Students}

Many students chose to study in vocational schools because they were specifically interested in vocational education. The students who earned good grades in lower secondary schools decided to attend vocational schools because they believed they could get a job after graduation. As one male teacher elaborated "The majority of children who chose to attend vocational schools by their own choice were more motivated and more eager to learn." Other students saw 
their family members or older siblings getting a successful job from vocational education, so they were interested in the programs. As one male Malay Muslim student observed: "Many students who graduated from a ship construction program earned a high income. Some of them work in foreign countries and get big bucks so I want to study, too".

\section{Emerging Themes: The Role of Vocational Education for the Local Community}

The number of children and young people involved in drug and substance abuse in the region is increasing. Therefore, the interviewers suggested vocational schools to distract these students from drugs by teaching them technical and vocational skills, particularly with boys in rural villages. The promotion of the development of a wide range of skills helped them cope effectively with the challenges of everyday life, increase their income, provide greater occupational choices, and increase their feelings of self-worth and self-confidence. "I wish vocational schools could teach boys and men in the community. I think that in my community most boys and men are not studying, some people become construction workers with a low income, because they are cheated by their brokers. I wish the mechanic teachers could come to teach them some skills for a year and go to the community. Some students do not have cars. No money to pay for commuting to schools. I wish vocational school could teach them so they could use their time wisely instead of being involved in drugs." 


\section{Collaboration with Malaysia and Indonesia}

One of the major issues in the Special Development Zone amidst the violent armed conflict is that there are few factories in the area, providing insufficient jobs for the number of students. Moreover, students often also want to develop their professional skills and have challenging learning experiences. They often get internships in Songkhla, Phuket and Surat provinces. Since the majority of the students in the region were mostly Thai-Malay Muslims, the area was highly multicultural. Therefore, the vocational schools from this region should collaborate with Malaysia and Indonesia. Hence, the students not only have opportunities to intern in those countries, but they can also have a chance to learn English and experience a different culture. "We should create a network with educational institutions in Malaysia and Indonesia. For example, students interning in Malaysia might have the courage to work there after their graduation as business owners have seen their talents and will be more likely to hire them. The advantage is that the Muslim children can learn those language faster than the Buddhist children. Therefore, it is important to learn the language. Children need to practice different languages."

\section{Discussion and Conclusion}

Vocational education is one of the alternative approaches to combat unskilled labor, insecurity and promoting sustainable peace (UNESCO, 2014). ${ }^{34}$ This study identified a con-

34 UNESCO, Education for Peace and Sustainable Development. 
tradiction to the popular belief associating a social stigma and a negative image with vocational education (Sangboonnum, 2013). ${ }^{35}$ Most people in this region realize the economic value of vocational education. However, there has been low enrollment of vocational students due to ethno-religious conflict (Harish, 2006). ${ }^{36}$ The Thai Buddhist families in the three southern border provinces and four districts of Songkhla feared that the insurgency could affect their children, so they transferred them to schools outside the conflict region. Consequently, most of the students remaining in the conflict regions are ethnic Thai-Malay Muslims, who prefer private Islamic schools to vocational schools. This is congruent with Engvall and Andersson's work (2014) ${ }^{37}$ on the dynamics of conflict in Southern Thailand. Moreover, the UNESCO report found that the demographic transformation of the Thai society greatly affects the dynamic of education system in Thailand (UNESCO, 2011).

Education in Thailand has undergone dramatic changes, reflecting globalization, neoliberalism and other global trends. The major shift of education policies is massification, privatization, and internationalization (UNESCO, 2011). Moreover, the expanding educational opportunities

Concepts, Clarity and Cohesion. A Set of Papers Commissioned by MGIEP, UNESCO, https://in.one.un.org/wp-content/uploads/2016/09/227521e. pdf [access: 19.08.2015].

35 Sangboonnum, C. Vocational Education Development: Lessons from Thailand. Ministry of Education, Thailand, http://yangon.sites.unicnetwork.org/files/2013/05/Voc-Edu_thailand_Ms_-Churairat-Sangboonnum__.pdf [access: 22.07.2015].

36 S. Harish, Ethnic or Religious Cleavage? Investigating the Nature of the Conflict in Southern Thailand, "Contemporary Southeast Asia: A Journal of International \& Strategic Affairs" 2006, No. 1, pp. 48-69.

37 A. Engvall, M. Andersson, The dynamics of conflict in southern Thailand, "Asian Economic Papers" 2014, No. 13, pp. 169-189. 
policy created more options for both Thai Buddhist students and Thai-Malay Muslim students as there are many new vocational schools and private Islamic schools opening in their communities. Therefore, Thai Buddhist students from neighboring provinces did not have to travel far to study in the Special Development Zone in Southern Thailand, especially Satun province. On the other hand, traditional Thai - Malay Muslim parents in the region were more likely to send their children to religious schools in a way that reflects their own religious values, even though they are likely to earn less as adults (Tuntivivat, 2016)..$^{38}$ As a result, traditional Thai-Malay Muslim parents need to balance the economic motives of educating children with the non-economic motives of school choice driven by their beliefs (World Bank, 2010; Funston, 2010; ${ }^{39}$ Doah, 2015). ${ }^{40}$

It is noteworthy to mention human rights discourse address human deprivation and suffering in the context of poverty based on race and ethnicity (McLaren, 2012). ${ }^{41}$ In this context, the Thai government has tried - through its different action plans - to give a novel impetus to the vocational education in the Special Development Zone of Southern Border Provinces. The implementation of voca-

38 S. Tuntivivat, The Inter-Relationship between Violence and Education amidst Armed Conflict in Southern Thailand, "Journal of Aggression Conflict and Peace Research” 2016, No. 4, pp. 269-278.

39 J. Funston, Malaysia and Thailand's Southern Conflict: Reconciling Security and Ethnicity, "Contemporary Southeast Asia" 2010, No. 2, pp. 234-235.

40 Doah P., Muslims in Thailand: A Minority Challenge. Religious Minorities' Report, http://www.onislam.net/english/back-to-religion/covering-religion/461080-muslims-in-thailand-a-minority-challenge.html [access: 22.07.2015].

41 P. McLaren, Revolutionary Critical Pedagogy for a Socialist Society: A Manifesto, “The Capilano Review” 2012. No. 13, pp. 61-66. 
tional education through promoting the value and cultural awareness of the local community by joining religious and secular principles called "Vocational Education for this Life and Next Life" played a very important educational role for Thai-Malay Muslim students and the physical and psychological needs of the parents.

This effort to increase ethnic Thai-Malay Muslim minority students was a positive trend in terms of vocational education enrollment as claimed by a recent report ibased on a survey in the 2015 academic year, which showed that the total number of vocational students in the region had increased by $9.73 \%$ percent. Students in Yala were more likely to be interested in vocational education, representing an increase of $26.7 \%$. The number of students in Narathiwat who chose vocational education had increased by $9.98 \%$. Nonetheless, in Pattani, the number of students interested in vocation education had dropped by $3.7 \%$ (The Government Public Relations, 2016). Therefore, the appropriate management of vocational education could be an effective tool to rebuild practical education, the local economy and strengthen social cohesion through the acquisition of ongoing employable skills and knowledge for all students (Yasin et al, 2013; ${ }^{42}$ United Nations, 2013). ${ }^{43}$

42 R. Yasin, Y. Faizal, C. Ridzwan1, H. Ashikin, R. Bekri, Current Trends in Technical and Vocational Education Research: A Meta-Analysis, "Asian Social Science" 2013, No. 13, pp. 243-251.

43 United Nations, A New Global Partnership: Eradicate Poverty and Transform Economies Through Sustainable Development. The Report of the High-Level Panel of Eminent Persons on the Post-2015 Development Agenda, Division for Sustainable Development Goals, https:// sustainabledevelopment.un.org/index.php?page =view\&type $=400 \& n-$ $\mathrm{r}=893$ \&menu=35 [access: 19.08.2015]. 
Based on the results of my study, this paper offers some policy recommendations for strengthening vocational education and training. They are as follows: (1) the vocational education system must be conceived in a more holistic way and academic, technical, and ethical knowledge needs to be integrated into a coherent system appropriated for the economic and socio-cultural environment of the local community; (2) the administration should continuously take notice of ethno-religious and cultural dimension, which will undoubtedly contribute to giving a new impetus to vocational education and training; and (3) the proper management of vocational education and training is not only a route to economic prosperity, but also reduces income inequality, sustainable peace, and social cohesion in the Special Development Zone of Southern Border Provinces.

\section{Bibliography}

Abassah M. (2011), Analysis of the Problems and Prospect of the Technical College Teachers in Nigeria. Proceedings of the 2011 International Conference on Teaching, Learning and Change (c) International Association for Teaching and Learning (IATEL), Retrieved on October 8, 2015 from http://www.hrmars.com/admin/pics/181.pdf.

Alessandri S.W., Modelling corporate identity: a concept explication and theoretical explanation, Corporate communications: Int. J., 2001, Vol. 6 (4).

Amedorme S.K. Yesuenyeagbe A.K.F., Challenges Facing Technical and Vocational Education in Ghana, "International Journal of Scientific \& Technology Research" 2013, Vol. 2, Issue 6. 
Bureau of Vocational Education Research and Development Retrieved on November 5, 2015, http://ver.vec.go.th/Portals/11/download/Filedowloand/summary_1.pdf.

Colley H., James D., Diment K., Tedder M., Learning as becoming in vocational education: class, gender and the role of vocational habitus, "Journal of Vocational education" 2003, Vol. 55 (4).

Dahil L., Karabulut A., Tahta F., Problems Encountered in Educating Qualified Workforce in Vocational High Schools and Solution Seeking, "The Online Journal of Quality in Higher Education" 2013, Vol. 1 (2).

Doah P., Muslims in Thailand: A Minority Challenge. Religious Minorities' Report. 15 March 2015, retrieved on 22 July, 2015, http://www.onislam.net/english/backto-religion/covering-religion/461080-muslims-in-thailand-a-minority-challenge.html.

Engvall A., Andersson M., The dynamics of conflict in southern Thailand, "Asian Economic Papers" 2014, Vol. 3 (13). European Union, The Benefits of Vocational education. European Centre for the Development of Vocational Training, 2011, Retrieved on December 29, 2015, http://www. cedefop.europa.eu/EN/Files/5510_en.pdf.

Eichhorst W., Rodríguez-Planas N., Schmidl R., Zimmermann K., A Roadmap to Vocational education Systems around the World, 2012, Retrieve on December 29, 2014, http://ftp.iza.org/dp7110.pdf.

Friberg K., Apprenticeship orientation as planned behavior in educational choices: a path model of antecedent beliefs, "Empirical Research in Vocational Training" 2014, Vol. 6 (7), https://doi.org/10.1186/s40461-014-0007-z.

Funston J., Malaysia and Thailand's Southern Conflict: Rec- 
onciling Security and Ethnicity, "Contemporary Southeast Asia" 2010, Vol. 32 (2).

Joll C., Religion and Conflict in Southern Thailand: Beyond Rounding Up the Usual Suspects, "Contemporary Southeast Asia" 2010, Vol. 32 (2).

Joseph E.B., Utin A.Y., Akpan G.A., Usoro H.S.U., Functional technical and vocational education for values, knowledge, skills and national development, "Journal of Pristine" 2013, Vol. 8 (1).

Harish S., Ethnic or Religious Cleavage? Investigating the Nature of the Conflict in Southern Thailand, "Contemporary Southeast Asia: A Journal of International \& Strategic Affairs" 2006, Vol. 28 (1).

Hoeckel K., Costs and Benefits in Vocational education, 2008, OECD office. Retrieved on December 29, 2015, http://www.oecd.org/education/innovationeducation/ 41538706.pdf.

Liow J., Religious Education and Reformist Islam in Thailand's Southern Border Provinces: The Roles of Haji Sulong Abdul Kadir and Ismail Lufti Japakiya, "Journal of Islamic Studies" 2010, Vol. 21 (1).

May T., Armed Conflict and Resolutions in Southern Thailand, "Annals of the Association of American Geographers" 2009, Vol. 99 (5).

McLaren P., Objection Sustained: revolutionary pedagogical praxis as an occupying force, "Policy Futures in Education" 2012, Vol. 10, No. 4.

McLaren P., Revolutionary Critical Pedagogy for a Socialist Society: A Manifesto, “The Capilano Review” 2012, Vol. 3 (13).

Melvin N.J., Conflict in Southern Thailand: Islamism. Violence and the State in the Patani Insurgency, SIPRI Policy 
Paper No. 20, September. Sweden: CM Gruppen, Bromma 2007.

Ministry of Education, Office of the Minister Newline, 1 April, 2015, retrieved on 22 July, 2015 http://www.moe. go.th/websm/2015/apr/116.html.

Moenjak T., Worswick C., Vocational Education in Thailand: A Study of Choice and Returns, "Economics of Education Review" 2003, Vol. 22.

Nitjarunkul K., Sungtong E., Placier P., Challenges of Educators in the Context of Education Reform and Unrest: A Study of Southern Border Provinces in Thailand, 'Asian Social Science" 2014, Vol. 10 (18).

Pimpa N., Suwannapirom S., Thai students' choices of vocational education: marketing factors and reference group, "Springer Science+Business Media. Educ Res Policy Prac" 2008, Vol. 7.

Phuangchan S., Sungtong E., Vanitsuppavong P., Choosuwan R., Management of Vocational Education Development of Special Administrative Development Zone in Southern Border Provinces, "Academic Services Journal Prince of Songkla University" 2015, Vol. 26 (2).

Sangboonnum C., Vocational Education Development: Lessons from Thailand. Ministry of Education, Thailand 2013, http://yangon.sites.unicnetwork.org/files/2013/05/ Voc-Edu_thailand_Ms_-Churairat-Sangboonnum-_.pdf. Suthieat T. (2008), Attitudes toward conflict behavior of vocational students (Unpublished master's thesis), Thammasat University, Bangkok, Thailand 2018. Retrieved May 1, 2015, http://tdc.thailis.or.th/tdc/basic.php.

The Basic Education Core Curriculum, 2008, academic. obec.go.th/web/doc/d/147.

Wisetsri P., Conflict between vocational students from differ- 
ent institutions (Unpublished master's thesis), 2011, Kasetsart University, Bangkok, Thailand. Retrieved May 1, 2015, http://tdc.thailis.or.th/tdc/basic.php.

Wonacott M., Vocational Education Myths and Realities. The ERIC Clearinghouse on Adult, Career, \& Vocational Education Myths and Realities Series: Benefits of Vocational Education, 2000, Retrieved on December 31, 2015, http://www. raisingspecialkids.org/_media/uploaded/j/0e1833985_jobvocationaleducationmythsandrealities.pdf.

UNESCO, Higher Education and Technical \& Vocational Education Training, 2011, http://www.unescobkk.org/ education/resources/resources/education-system-profiles/thailand/higher-tvet/.

UNESCO, Lifelong Learning. Unesco Institute of Lifelong Learning, 2013, Retrieved on 19 August, 2015, http:// uil.unesco.org/home/programme-areas/lifelong-learning-policies-and-strategies/news-target/lifelong-learning/9bf043146eaa0985e05daa9e12135f5b/.

UNESCO, Education for Peace and Sustainable Development. Concepts, Clarity and Cohesion, A Set of Papers Commissioned by MGIEP, 2014.

United Nations, A New Global Partnership: Eradicate Poverty and Transform Economies Through Sustainable Development. The Report of the High-Level Panel of Eminent Persons on the Post-2015 Development Agenda, 2013.

United Nations General Assembly Thematic Debate on Education in Emergencies, 18 March 2009, retrieved on 22 July, 2015, http://www.ineesite.org/en/education-in-emergencies/un-education/ga-debate.

Uwanno B., Conflict in Thailand: Causes, impact, and solution, 2010, http:// www.oknation.net/blog/nhongkampangdin/2010/03/28/entry-1. 
Vocational Education Commission, Dropout Problems of Students in Vocational education Report, Thai 2014. Yasin R.M., Nur Y.F.A., Ridzwan C.R., Ashikin H.T., Bekri R.M., Current Trends in Technical and Vocational Education Research: A Meta-Analysis, "Asian Social Science" 2013, Vol. 9 (13).

Yusef I., The Southern Thailand Conflict and the Muslim World, "Journal of Muslim Minority Affairs" 2007, Vol. 27 (2). Tuntivivat S., The Inter-Relationship between Violence and Education amidst Armed Conflict in Southern Thailand, "Journal of Aggression Conflict and Peace Research" 2016, No. 4.

\begin{abstract}
Vocational education is a major tool to sustain peace. The purpose of this research is to investigate the underlying conditions influencing the decisions of students to pursue vocational education for sustainable peace in southern Thailand. This qualitative case study involved document reviews, site observations, focus groups and face-to-face interviews with thirty-one key informants, including students, parents, teachers, guidance counsellors, and principals from six vocational colleges in the five provinces of the special development zone in southern Thailand, consisting of Satun, Yala, Pattani, Narathiwat, and four districts in the upper southern province of Songkhla. The study found that ethno-religious conflict, social environment, public policy intervention, student choice and expectation, as well as role of vocational education in the local community, and collaboration with Malaysia and Indonesia were underlying conditions influencing vocational education for sustainable peace in southern Thailand. The paper also offered some policy implications on vocational education for sustainable peace.
\end{abstract}

Keywords: Vocational Education, Sustainable Peace, Ethno-religious Conflict, Youth Empowerment, Ethnic Minority 


\author{
Vanessa Tinker \\ Collegium Civitas, Department of International Relations, Warsaw
}

\title{
The Role of Education in Turkey's Intractable Conflict and Failed Peace Process
}

\section{Introduction}

Hopes for ending three decades of intractable conflict, ${ }^{1}$ which has impeded the country's modernization and democratization efforts, and for resolving the Kurdish Question were dashed in 2015 when the peace process collapsed, and violence renewed between the Republic of Turkey, led by the Justice and Development Party (Adalet ve Kalkınma Partisi, AKP), and the Kurdistan Workers' Party (Kurdish: Pariya Karkerên Kurdistan, PKK) referred to for the remainder of this paper as AKP and PKK respectively. The Kurdish Question, Christofis posits, "emerged as the central outcome of the homogenizing Kemalist nation-building process, the principal aim of which was to 'Turkify' the disparate identities within the newly created state."2 Savron

1 The term intractable conflict is often used to describe contemporary intra-state conflicts that Bar-Tal and Rosen describe "as lasting at least 25 years and as being fought over goals that are perceived of as existential; they are violent, perceived as unsolvable, of a zero-sum nature, and preoccupying society members greatly; and the parties involved invest much in their continuation (2007: 557).

2 N. Christofis, The State of the Kurds in Erdoğan's 'New' Turkey, "Journal of Balkan and the Near Eastern Studies" 2019, No. 21, Vol. 3, p. 251. 
points out, "The Kurdish population experienced political and economic exclusion with severe restrictions imposed on their identity and civic rights. Kurds were deprived of freely expressing their culture, language and traditions and, worse, their very existence was denied." In response, a number of Kurdish rebellions broke out in the 1920s and 1930s that were brutally quashed by the Turkish army. Then, in 1984, the Kurdish guerrillas entered in violent clashes with the Turkish army that have been ongoing ever since resulting in 40,000 deaths, nearly a million displaced persons, high levels of trauma and significant economic costs. ${ }^{4}$

Given the complex social, political, economic, cultural, psychological, and security implications it is apparent that a holistic approach is needed, one that addresses the different dimensions of the conflict and seeks to challenge nad transform existing worldviews from a culture of conflict to a culture of peace, ${ }^{5}$ if there is any future hope of a new peace process. Of the many socializing agents needed to transform a society to a culture of peace (i.e. political, societal, cultural, mass communication, leadership, and elites' participation), this article focuses on one of them - education.

3 A. Savran, The Peace Process between Turkey and the Kurdistan Workers' Party, 2009-2015, "Journal of Balkan and Near Easter Studies" 2020, No. 22, Vol. 6, p. 778.

4 Y. Ensaroğlu, Turkey's Kurdish Question and the Peace Process, "Insight Turkey" 2013, No. 15, Vol. 2; A.Villellas, Turkey and the Kurdish question: Reflecting on peacebuilding, "Quaderns de Construccio de Pau" 2011, No. 22.

5 UN states that, "The culture of peace is based on the principles established in the Charter of the United Nations and on the respect for human rights, democracy and tolerance, the promotion of development, education for peace, the free flow of information and the wider participation of women as an integral approach to preventing violence and conflicts, and efforts aimed at the creation of conditions for peace and its consolidation (A/Res/52/13, 15 January 1998, para. 2). 
Literature and research analysing the "peace" 6 process have identified several factors that contributed to its failure, ranging from Erdoğan's domestic political priorities, the Turkish state's fear of Syrian Kurdish autonomy, regional developments, local dynamics in south eastern Turkey and missteps taken during the peace process. ${ }^{7}$ However, scant attention has been paid to the role of education in Turkey's intractable conflict and failed peace process. This paper seeks to address the overlooked and yet crucial dimension.

Before turning to the case of Turkey, this paper first provides the framework for analysing the role of education in intractable conflicts and examines the ways it can inhibit or contribute to peace processes, referred to by Bush and Sal-

6 It should be noted here that there remains no consensus as to what the official name of this process is called. For example, the AKP has largely referred to this process as a "solution process" while most other parts of civil society have called it the "peace process". This is in part because there remain different conceptualizations of peace. Traditionally, peace referred to the absence of war and direct violence. Johan Galtung, often referred to as the father of peace studies, expanded the definition of peace by introducing the distinction between negative and positive peace. Negative peace refers to the absence of direct or physical violence (i.e. war, gang attacks, sexual assault, random killing, and all other forms of physical harm). Positive peace represents the existence of social and cultural structures that contribute to the well-being of all citizens. Both definitions of peace represent Galtung's unique distinction of different types of violence, which include direct violence (verbal, physical, and violence harming the body, mind, or spirit), structural violence (political, repressive, economic, exploitative; supported by structural penetration, segmentation, fragmentation and marginalization), and cultural violence (as embedded in religion, law, ideology, language, art, empirical/formal science, cosmology and disseminated and sustained in schools, universities, media) (see Galtung 1996).

7 See for example G. Lindenstrauss, Back to Square One? The Collapse of the Peace Process with the Kurds in Turkey, "Strategic Assessment" 2016, No. 18, Vol. 4; M. Hoffman, The State of the Turkish-Kurdish Conflict, "Center for American Progress" 2019; A. Savran, The Peace Process between Turkey and the Kurdistan Workers' Party, 2009-2015, "Journal of Balkan and Near Easter Studies" 2020, No. 22, Vol. 6. 
tarelli as the positive and negative faces of education. ${ }^{8}$ Using this lens, the paper then examines the case of Turkey seeking to understand the role education has historically played in the intractable conflict between the Government and the PKK. Throughout the Republic of Turkey's history and even until now, this paper argues that education has been used as a political tool by the various governments to transform society according to their different agendas. This paper begins with a historical analysis of education first under Mustafa Kemal Atatürk, the founder of the modern Republic of Turkey, and then examines the educational policies of his successors. As this paper demonstrates, since the foundation of the Republic the education system has contributed to the intractable conflict with the PKK by promoting a narrow, exclusive, and discriminatory vision of the Turkish nation.

After providing a historical review of Turkey's education system, the paper then shifts its focus to the AKP, which has governed Turkey since 2002. This paper underlines how under the AKP, the education system has undergone constant changes structurally and ideologically. As Karapehlivan discusses, "Education policies under the AKP rule have been shaped by an amalgamation of neoliberalism, conservatism and Islamism." ${ }^{9}$ In return, these changes have significantly impacted all aspects of society, including the peace process. Despite adopting and supporting a number of peace education-related initiatives (i.e. human rights, democracy, citizenship, and conflict resolution skills elective courses

8 K.D. Bush, D. Saltarelli, The Two Faces of Education in Ethnic Conflict, New York 2000.

9 F. Karapehlivan, Constructing a "New Turkey" through education. An overview of the education policies in Turkey under the AKP rule, "Heinrich Böll Stiftung" 2019, par. 
and/or programs at the primary, secondary, and tertiary level), this paper argues that they were not given adequate attention or support and failed to be included as part of the infrastructure of the peace process, representing a missed opportunity for social transformation towards a culture of peace.

The paper concludes by arguing for a major overhaul in Turkey's education system, needed if there is to be any future prospects for a new and sustainable peace process. Instead of using education as a tool to promote a narrow, exclusive and discriminatory vision of the Turkish nation, this paper contends peace education is needed as a tool for social transformation and creating a culture of peace instead of a culture of violence. Drawing from and applying BarTal and Rosen's framework to the case of Turkey, this paper outlines the necessary socio-political conditions needed to successfully integrate and mainstream peace education in Turkey. Provided the current socio-political conditions may not be ripe for mainstreaming, this paper suggests resuming and strengthening current peace education initiatives and introducing new ones with the support of international, regional, and local stakeholders.

\section{The Positive and Negative Faces of Education}

Education represents one of the key institutions in creating the modern state, in terms of its role in developing new and competent members of society, as well as acting as a major socializing agent through its transmission of knowledge largely carried out through the standardization of curriculum that reproduces a society's ideology and normative sys- 
tem. The educational system also serves as a link between the state and society by creating a common civic identity, while protecting and promoting localized identities. The importance and far-reaching impact of the educational system helps explain why it remains central in domestic politics of many nations.

However, mounting evidence by researchers and practitioners has shown that education can also play a destructive role by contributing to the outbreak and development of violent conflicts. ${ }^{10}$ An in-depth study by Bush and Saltarelli examines and highlights the positive and negative faces of education in relation to ethnicity and conflict, looking at the role of schools in intensifying social divisions, and expediting the outbreak of political violence. ${ }^{11}$ A report prepared by the World Education in Dakar (UNESCO, 2000) found that the content, structure and delivery of education may themselves serve as a catalyst of violent conflicts by reinforcing social fissures. ${ }^{12}$ In countries such as Lebanon, Northern Ireland, Mozambique, and Bosnia and Herzegovina, for example, it was reported that education was, and in the case of Bosnia and Herzegovina, is still being used as a weapon in cultural repression, to manipulate history for political purposes, and reinforce segregation, inequality, and stereotyping. ${ }^{13}$

10 S. Tawil, H. Alexandra, Education, Conflict and Social Cohesion, Geneva 2004.

11 K.D. Bush, D. Saltarelli, The Two Faces of Education in Ethnic Conflict, New York 2000.

12 UNESCO, World Directory of Peace Research and Training Institutions, Paris 2000.

13 See for example S. Tawil, H. Alexandra, Education, Conflict and Social Cohesion, Geneva 2004; World Bank, Reshaping the Future: Education and Post-Conflict Reconstruction, Washington DC 2005; R. Toè, 
Research on countries emerging from violent conflicts has shown that education systems play a negative role and undermine peace processes by reinforcing social divisions that served as the deepest cause of the violent conflict to begin with. ${ }^{14}$ Alternatively, studies have also recognized the positive and strategic role of education by preventing the relapse of conflict and assisting in peace processes. ${ }^{15}$ With this growing awareness the international community along with many countries currently in and/or emerging from violent conflicts has sought to adopt and support a number of peace education-related projects (e.g. human rights, democracy, citizenship, and conflict resolution skills courses) and mainstream them into formal education systems since it is assumed that they will assist in peace-building efforts by dampening the impact of conflict, fostering an ethically tolerant climate, desegregating minds, improving linguistic tolerance, promote a sense of inclusive citizenship, assist in the disarmament of history, educate on how to become peacemakers and show ways to prevent conflicts. ${ }^{16}$ Peace education has also been

Bosnia's Segregated Schools Perpetuate Ethnic Division, "Balkan Transitional Justice", 15 July 2016; Perry, V., The Myth of Incremental Education Reform in BiH, „Democratization Policy Council”, 3.02.2021.

14 A. Smith, and T. Vaux, Education, Conflict, and International Development, London 2003; A. Smith, The Influence of Education on Conflict and Peace Building, "Background Paper Prepared for the Education for All Global Monitoring Report 2011: The Hidden Crisis - Armed Conflict and Education", Paris 2010.

15 M. Fitzduff, I. Jean, Peace Education: State of the Field and Lessons Learned From USIP Grantmaking, Washington DC 2011; S. Fountain, Peace Education in UNICEF, "Working Paper Series, Programme Division, Education Section", New York 1999; K. Tomlinson, and P. Benefield, Education and Conflict: Research and Research Possibilities, "National Foundation for Educational Research" 2005.

16 V. Tinker, Peace Education as a Post-Conflict Peacebuilding Tool, "All Azimuth" 2016, No. 5, Vol. 1. 
regarded as a means of spreading Western-core values and beliefs of democratic governance, free market economics and human rights through discourses implanted into curriculums, teacher instruction, and the structures in educational institutions. ${ }^{17}$ Finally, peace education has been regarded as crucial in linking the grassroots to the overall policies of sustainable peace through normative links to both the top levels of elites and bottom level grassroots. ${ }^{18}$

After examining the potential negative and positive roles of education in intractable conflicts and peace processes, the paper adopts and applies this framework to analyse the case of Turkey. In this next section, the paper analyses the role education historically played in the intractable conflict between the Government and PKK.

\section{Education as Part of the Modernization Project of the Turkish Republic}

In the case of Turkey, education has served as a powerful tool to transform and reform the public and private lives of citizens to create a modern Turkish society out of a multi-ethnic Ottoman empire. Formal education in Turkey was and remains highly centralized, with the State playing an active role in what is taught and how it is taught throughout the country. In its formative years, Mustafa Kemal Atatürk, the founder of the modern Republic of Turkey and

17 O. Richmond, The Transformation of Peace, Houndsmill 2007.

18 M. Fitzduff, I. Jean, Peace Education: State of the Field and Lessons Learned from USIP Grantmaking, Washington DC 2011; V. Perry, S. Keil, The OSCE Mission in Bosnia and Herzegovina: Testing the Limits of Ownership, "Nationalities Papers: The Journal of Nationalism and Ethnicity" 2013, No. 41, Vol. 3. 
his successors sought to modernize the education system. Karapehlivan explains, "education had three important roles to fulfil, namely the implementation of the modernisation project, the formation of the nation-state and the achievement of the economic development." ${ }^{19}$ Establishing secular education was critical to the development of the Republic of Turkey and defining what it meant to be a Turkish citizen, portrayed as modern, Western, Turkish, and obedient. ${ }^{20}$ In what İnce refers to as the "official citizenship cult text" - Vatandaş İçin Medeni Bilgiler (Civic Information for the Citizen), it provides insight into how Atatürk and other Republican elite interpreted the Turkish nation, described as unified politically, linguistically, territorially, racially, historically, and morally. ${ }^{21}$

In the early years of the Republic of Turkey, efforts were underway to strike a balance between creating a distinct Turkish identity and culture on the one hand, while embracing universal and western norms on the other. Although the education system made references to universal principles of human rights, democracy, and citizenship, Çayır and Gürkaynak posit it largely was interpreted within a parochial, duty-based, nationalistic and militaristic framework. ${ }^{22}$

19 F. Karapehlivan, Constructing a "New Turkey" through education. An overview of the education policies in Turkey under the AKP rule, "Heinrich Böll Stiftung", 2019, par. 2.

20 K. Çayir, İ. Gürkaynak, The State of Citizenship Education in Turkey: Past and Present, "Journal of Social Science Education" 2008 No. 6, Vol. 2; B. İnce, Citizenship Education in Turkey: Inclusive or Exclusive, “Oxford Review of Education" 2012, No. 28 Vol. 2; F. Karapehlivan, Constructing a "New Turkey" through education. An overview of the education policies in Turkey under the AKP rule, „Heinrich Böll Stiftung”, 2019.

21 B. İnce, Citizenship Education in Turkey: Inclusive or Exclusive, "Oxford Review of Education" 2012, No. 28, Vol. 2, p. 119.

22 K. Çayir, and İ. Gürkaynak, The State of Citizenship Education 
Furthermore, the education system followed a policy of uniformity, ignoring lingual, ethnic and cultural diversity of the Kurdish as well as other minorities. ${ }^{23}$ As Ince points out, many other predominantly Muslim ethnic and linguistic communities, such as Lazes, Romas, Circassians and Arabs, also reside in Turkey, along with the largest religious minority group - Alevis, and non-Muslim minorities such as Jews, Armenians and Geeks. ${ }^{24}$ To create a modern homogeneous nation-state out of the multi-ethnic Ottoman Empire, Ince argues citizenship education was the vital part of the Republic's project. ${ }^{25}$ Ince demonstrates this by citing the slogan used by the Republican Peoples Party (Cumhuriyet Halk Partisi, CHP) 'one language, one culture, one ideal'. It remained the sole political party ruling the Republic of Turkey till 1946. ${ }^{26}$ The education system also instilled a sense of fear of external enemies. Earlier civic education textbooks for example, and even up until the 1980s, "inculcated the 'Sèvres Syndrome', which refers to the conviction that Turkey is surrounded by enemies intent on dividing it, à la Treaty of Sèvres, which was imposed on the Ottoman government by the victorious Western powers at the end of the First World War." ${ }^{27}$

in Turkey: Past and Present, "Journal of Social Science Education” 2008, No. 6, Vol. 2, p. 51.

23 K. Çayir, İ. Gürkaynak, The State of Citizenship Education in Turkey: Past and Present, "Journal of Social Science Education" 2008, No. 6, Vol. 2; K. Nurcan, Discrimination Based on Colour, Ethnic Origin, Language, Religion and Belief in Turkey's Education System, Istanbul 2015.

24 İnce, Citizenship Education in Turkey: Inclusive or Exclusive, "Oxford Review of Education" 2012, No. 28, Vol. 2, p. 116.

25 Ibidem.

26 Ibidem, p. 119.

27 Ibidem. 
Throughout the history of the education system in Turkey, it has gone through a number of transitions as various governments have used it as a political tool to further their different agendas. In the formative years, the Republic of Turkey sought to eradicate the dual structure of education that included both secular and religious educational institutions by establishing the Law of Unification of Instruction passed in 1924, which abolished all religious instruction in state schools placed under the control through the Ministry of National Education. ${ }^{28}$ Soon after that, significant reforms followed, such as the introduction of co-education and the Latin alphabet. The education system sought to create citizens to be "secular", "modern" and those devoted to "Atatürk's" principles. ${ }^{29}$ Textbooks emphasized national unity and solidarity as the basis of "Turkishness". However, the issue of whether Turkish citizenship was based on legal-political or ethno-cultural terms was and continues to be contested. ${ }^{30}$ In either case, as this section has highlighted, the political notion of citizenship was exclusionary and differential, following a series of homogenizing policies that ignored the existence of any lingual, ethnic and cultural diversity. In the case of Kurdish, they were not recognized

28 F. Karapehlivan, Constructing a "New Turkey" through education. An overview of the education policies in Turkey under the AKP rule, "Heinrich Böll Stiftung" 2019, par. 2.

29 A.G. Altinay, The Myth of the Military-Nation: Militarism, Gender, and Education in Turkey, New York 2004; K. Çayir, and İ. Gürkaynak, The State of Citizenship Education in Turkey: Past and Present, "Journal of Social Science Education" 2008, No. 6, Vol. 2; K. Nurcan, Discrimination Based on Colour, Ethnic Origin, Language, Religion and Belief in Turkey's Education System, Istanbul 2015.

30 K. Çayir, İ. Gürkaynak, The State of Citizenship Education in Turkey: Past and Present, „Journal of Social Science Education” 2008, No. 6, Vol. 2. 
as a distinct ethnic group and the Kurdish language was deemed as a degenerated dialect of Turkish. ${ }^{31}$

The Republic of Turkey did make positive advances in the 1950s towards democratization, when transitioning from a single party to a multi-party system, and these changes were reflected in the education system, which sought to introduce courses on democratic citizenship. However, the secularization process of education was disrupted in 1950 when the conservative Democratic Party (DP) came into power. It sought to gradually reverse the secular educational reforms by re-opening and increasing the number of Imam Hatip Schools (referring to Imam and preacher schools). As Karapehlivan explains, Imam Hatip Schools were developed as an alternative to the secular education system, thereby re-establishing a dual structure (secular and religious) education system. ${ }^{32}$ He maintains the hegemonic battle between the secular and religious factions continues to play out in the present education system. ${ }^{33}$

From 1950s to the beginning of 1971, regulations concerning citizenship were gradually liberalized and encouraged the spirit of freedom and solidarity that promoted active citizenship. This was reflected in the push for democratic citizenship education and observed in civic textbooks, which, as Ince argues, "emphasised democracy and citizenship rights more than they did in the previous

31 B. Can, F. Gök, S. Şimșek, The Role of Teachers in Building Societal Peace / How is the Kurdish Issue Projected onto School?, Istanbul 2013.

32 F. Karapehlivan, Constructing a "New Turkey" through education. An overview of the education policies in Turkey under the AKP rule, "Heinrich Böll Stiftung" 2019, par. 3.

33 Ibidem, par. 6. 
period". ${ }^{34}$ As democratic citizenship education gained momentum, for the first time textbooks discussed the rightsbased understanding of citizenship with its universal connotations.

These positive advancements, however, were short-lived and impeded by the military in 1971, when it stepped in and sought to reintroduce the pre-1960 discourse in the education policy of "upholding Turkish nationalism" and respecting Turkish values. ${ }^{35}$ Ensaroğlu argues that "The Republic embraced the Turkish identity as a primary source of unity and sought to subdue all non-Turkish elements through denial." ${ }^{36}$

This negative trend was further exasperated following the coup d'état of 12 September 1980, which reaffirmed the perception of threats deriving from internal and external enemies in the education system. ${ }^{37}$ Kurdish people came to be identified as an internal enemy and a threat to the livelihood of Turkey with their claims of cultural, lingual, and identity rights, as well as demands for autonomy and selfdetermination. ${ }^{38}$ The State feared that PKK demands would lead to Kurdish secession and that by recognising the Kurdish identity, it would undermine the Kemalist interpreta-

34 İnce, Citizenship Education in Turkey: Inclusive or Exclusive, "Oxford Review of Education" 2012, No. 28, Vol. 2, p. 122.

35 K. Çayir, İ. Gürkaynak, The State of Citizenship Education in Turkey: Past and Present, "Journal of Social Science Education" 2008, No. 6, Vol. 2.

36 Y.Ensaroğlu, Turkey's Kurdish Question and the Peace Process, “Insight Turkey" 2013, No. 15, Vol. 2, p. 8.

37 İnce, Citizenship Education in Turkey: Inclusive or Exclusive, "Oxford Review of Education" 2012, No. 28, Vol. 2.

38 N. Christofis, The State of the Kurds in Erdoğan's 'New' Turkey, "Journal of Balkan and the Near Eastern Studies" 2019, No. 21, Vol. 3, p. 253. 
tion of a unitary state. In response to Kurdish demands, the Turkish military responded with violence and/or ideological repression mechanisms, such as denying them of their human rights in terms of ethnic identification and the ability to learn in their mother tongue. It was within this context that the PKK was born, recruiting its leadership and membership from among the disenfranchised and served as a catalyst to spur what would become a three-decade intractable conflict with the Government in Turkey.

The 1980 military coup also signified the beginning of the neoliberal era in Turkey's history as well as a new official ideology referred to as the Turkish-Islamic Synthesis. According to Karapehlivan, the new ideology combined Turkish nationalism and Islam that changed in emphasis depending on the needs of the Government as evident in educational policies. ${ }^{39}$ This development was apparent in the1982 Constitution, which outlines in Article 24 a new course called 'Religious Culture and Moral Knowledge' to be taught in primary and secondary schools from a predominantly Sunni Islamic perspective. ${ }^{40}$ In civic education textbooks published after 1980, Ince argues how the orthodox understanding of Islam became one of the defining characteristics of the nation, how duties were once again given greater weight than rights, how critical thinking is nowhere to be found, or any discussion on the importance of citizenship participation. ${ }^{41}$ Ince explains, "The state uses

39 F. Karapehlivan, Constructing a "New Turkey" through education. An overview of the education policies in Turkey under the AKP rule, „Heinrich Böll Stiftung” 2019, par. 6.

40 Ibidem"

41 İnce, Citizenship Education in Turkey: Inclusive or Exclusive, "Oxford Review of Education" 2012, No 28. Vol. 2, p. 124. 
civic education as a tool to develop 'self-sacrificing' 'good citizens', who should always be alert for 'enemies' and ready to protect the unity of the nation" and argues, "This has burdened young citizens with a great responsibility and fosters xenophobia." ${ }^{42}$

In the 1990s, Turkey became increasingly engaged in the global economy and implemented several education reforms as an effort to join the European Union (EU) when recognised as a EU candidate in 1999. Additionally, Turkey made huge strides in aligning its legal structure in conformity with international treaties and human rights laws. These reforms were reflected in the education system with a number of courses offered on human rights, democracy, and citizenship education. A number of these themes were also integrated into the school curriculum. Although they represented important steps in the development of democracy and human rights culture, they still failed to address the deep-rooted issues within society, thereby inhibiting the prospects of creating a culture of peace. Furthermore, İnce suggests that courses such as Citizenship and Human Rights were implemented not because of Turkey's changing moral or ethical principles, but because they served as a means to boost the Country's international reputation..$^{43}$ And despite these promising advancements, the education system, as this next section will demonstrate, continues to promote the exclusive conceptualisation of Turkish national identity and citizenship.

42 Ibidem, p. 125.

43 Ibidem. 


\section{Education under the AKP}

Since the AKP came to power in 2002, the education system in Turkey has undergone radical structural and ideological changes. Scholars suggest that AKP's education reforms have sought to 'Islamise Turkey' by constructing a new national identity and producing 'pious generations. ${ }^{\text {'4 }}$ Although the advancement of promoting a conservative religious ideology dates back as early as to the 1950s, AKP helped accelerate these efforts with the aim of replacing the Kemalist and secular foundations of the education system and replacing them with a new founding ideology. ${ }^{45}$

Under AKP's rule, educational reforms initially sought to align with EU standards and neoliberal policies consisting of revisions in primary school curriculum content, textbooks, pedagogical approaches and installing an assessment system that followed a constructivist, student-centred, competency-based curriculum approach. ${ }^{46}$ However, as Sen and Starkey point out, power struggles often played out within the Ministry of National Education (MoNE) amongst different actors involved in curriculum reform including the Council of Europe (CoE) officials, the proponents of the CoE's internationalist model, secular nationalists, Islamist

44 A. Sen, H. Starkey, Citizenship Education in Turkey: From Militant Secular to Islamic Nationalism, London 2019; A. Kaya, Islamisation of Turkey under the AKP Rule: Empowering Family, Faith and Charity, "South European Society and Politics" 2015, Vol. 1, No. 20.

45 F. Karapehlivan, Constructing a "New Turkey" through education. An overview of the education policies in Turkey under the AKP rule, "Heinrich Böll Stiftung" 2019, par. 6.

46 Ibidem. 
nationalists. ${ }^{47}$ As demonstrated, curriculum reforms such as those made in the Citizenship and Human Rights Education textbook, ended up being subverted to promote militaristic nationalistic content instead. Human rights and democracy courses have often been presented in the education system from a statist perspective rather than from a human rights-based approach that embraces a universalistic vision. ${ }^{48}$ Citizenship, for example, is often conceptualized according to nationalistic, militaristic, and particularist elements. And democracy remains conceptualized as a voting process, one that does not encourage active citizen participation but rather focuses on voting under times of elections. The state in fact is presented as a metaphysical institution which cannot be criticized. Criticizing the state and/or the official ideology is equated with the strategies of anti-systematic movements. ${ }^{49}$ Turkish education promotes unreflective patriotism which glorifies the existing system. It encourages passive citizenry burdened with duties to protect the national unity and the indivisibility of the country. ${ }^{50}$ As the study has highlighted, despite calls for critical and reflective thinking in schools, tolerance, respect for human rights, citizens' rights and freedoms, there remain many contradictory elements in textbooks such as the emphasis on duties over rights, the absence of any discussion of other ethnic and religious minorities living in Turkey or making mention of the active participation of citizens aside from voting to note just a few.

47 A. Sen, H. Starkey, Citizenship Education in Turkey: From Militant Secular to Islamic Nationalism, London 2019.

48 Ibidem.

49 Ibidem.

50 Ibidem. 
In addition to the curriculum challenges in Turkey's education, the current pedagogical approaches in Turkey remain largely mechanistic, focussed on the passive reception of knowledge and then disseminating it to students. Although some efforts have been made to introduce student-centred learning as previously noted, research suggests the style of teaching remains teacher-centred with little feedback and input from the students. ${ }^{51}$ When addressing sensitive topics such as the Kurdish Question, the Turkish-Armenian controversy, gender discrimination, religion, the Kemalist ideology and so forth, a study by Can, Gök, and Şimşek found that teachers have either avoided the topics completely or reinforced the normative framework provided by the State system, thereby reinforcing the deep-rooted issues that spurred the conflict in the first place..$^{52}$ Other obstacles included the lack of trust towards the "other", unequal representation and reputation of different identities, cultures, and languages. ${ }^{53}$ There remains extensive pedagogical and psychological damage that still needs to be addressed.

Alongside these reforms, in 2009 the AKP initiated the first official attempt at finding a political solution to the Kurdish Question, to finally bring an end to the intractable conflict. This first peace initiative, referred to as the Kurdish Opening, initially granted greater cultural and linguistic rights to the Kurdish, but did not go far enough to bring about any significant results to transform the deep-rooted causes of the conflict..$^{54}$ This soon became apparent when

51 B. Can, F. Gök, S. Şimșek, The Role of Teachers in Building Societal Peace / How is the Kurdish Issue Projected onto School?, Istanbul 2013.

52 Ibidem.

53 Ibidem.

54 N. Christofis, The State of the Kurds in Erdoğan's 'New' Turkey, 
the Kurdish Opening abruptly ended in 2011 because of "political crises and a lack of commitment." 55 As noted, "while the AKP government has been more open-minded than any previous government in Turkish history regarding the Kurds, these gestures have been systematically presented as 'charity', or 'gifts, of the state's paternalists policy, rather than the genuine recognition of the Kurdish people and their identity. ${ }^{56}$ This has been apparent in a number of Government education initiatives such as the first newly established Mardin Artuklu University (MAU) that launched an academic institution called the 'Institute of Living Languages in Turkey' offering courses in Arabic, Assyrian, and Kurdish culture, history and languages. It represented the first official institution in Turkey to offer a degree in Kurdish. However, as noted:

From the day it was launched, the fate of the Kurdish Culture and Language (or "Kurdology"), the Program at MAU was tied to the political process known as the Kurdish opening - or democratic opening - in Turkey... [and reflected] the broader political framework for the so-called Kurdish question in the country and reveal[ed] how the basic right to education in Kurdish was turned into a political tool in the hands of the government. ${ }^{57}$

To serve as another illustration, in their study, Can, Gök, and Şimşek cite how Kurdish was offered as an elective for

"Journal of Balkan and the Near Eastern Studies" 2019, No. 21, Vol. 3, p. 254.

55 A. Savran, The Peace Process between Turkey and the Kurdistan Workers' Party, 2009-2015, "Journal of Balkan and Near Easter Studies" 2020, No. 22, Vol. 6, p. 778.

56 N. Christofis, The State of the Kurds in Erdoğan's 'New' Turkey, "Journal of Balkan and the Near Eastern Studies" 2019, No. 21, Vol. 3, p. 254.

57 N.O. Gündoğan, Kurdology in Turkey: Barometer of the "Peace Process" (Part 1), "Jadaliyya", 2.11.2020. 
two hours once a week arguing how this was far from satisfactory. ${ }^{58}$ They also identified other obstacles including: the lack of qualified teachers to teach Kurdish, lack of communication between parents and students about the elective courses, and/or an unwillingness of school administration to open elective courses voiced by teachers and parents. ${ }^{59}$ Teachers interviewed in the study complained that the teachers' training system was not sufficient in providing skills for dealing with problems based on social conflict and it did not provide an intercultural pedagogical training. ${ }^{60}$ Furthermore interviewees stated that the Ministry of Education was insufficient and failed to provide skills that would empower them in terms of conflict resolution, peace-building, and reconciliation.

From 2013 to 2015, the AKP intensified its efforts to resolve over three decades of fighting with the PKK. Unlike the AKP's previous negotiations with the PKK, which had largely been conducted in secret, the Peace Process turned into a public one, which the Kurdish side had demanded from the onset. Although the Peace Process was relatively inclusive, "it was elite-led with civil society and women largely excluded despite some 'breakfast meeting' with different social groups and the dedication of the Wise Men Commission (a group of notable Turkish figures tasked with explain[ing] the process to the public and gathering their views)." ${ }^{61}$ As Savran correctly points out, the Peace Process

58 B. Can, F. Gök, S. Şimşek, The Role of Teachers in Building Societal Peace / How is the Kurdish Issue Projected onto School?, Istanbul 2013.

59 Ibidem, p. 15.

60 Ibidem, p. 22.

61 A. Savran, The Peace Process between Turkey and the Kurdistan Workers' Party, 2009-2015, "Journal of Balkan and Near Easter Studies" 2020, No. 22, Vol. 6, p. 778. 
would have been more secure, had simultaneous dialogue taken place at all levels of society. ${ }^{62}$ Furthermore, this paper contends that peace education should have been included and prioritized as part of the infrastructure of the Peace Process to assist with the peacebuilding process. Despite adopting and supporting several peace education-related initiatives (i.e. human rights, democracy, citizenship, and conflict resolution skills elective courses and/or programs at the primary, secondary, and tertiary level), they were not given adequate attention or support and were not included in the infrastructure of the peace process, representing a missed opportunity for social transformation and the creation of a culture of peace.

Ultimately, after the Peace Process collapsed, the AKP has continued with its efforts de-secularise the education system such as reintroducing religious holidays to the school calendar, increasing the number of Imam Hatip Schools, offering more religious electives while removing other nonreligious ones. ${ }^{63}$ And although religious education courses claim objectivity, Karapehlivan argues they are taught from a Sunni Islam interpretation with little reference to other world religions. ${ }^{64}$ Additionally, students coming from other faiths often are forced to take these religious courses by law, thereby facing new exclusionary practice. ${ }^{65}$

62 Ibidem.

63 B. Can, F. Gök, and S. Şimşek, The Role of Teachers in Building Societal Peace / How is the Kurdish Issue Projected onto School?, Istanbul 2013, p. 22.

64 Ibidem.

65 A. Gürcan, The Problems of Religious Educatoin in Turkey: Alevi Citizen Action and the Limits of ECtHR, "Sabanc1 University IPC-Mercator Policy Brief" 2015. 
The process of de-secularizing Turkey's education system received further impetus following the military coup attempt 15 July 2016, whereby in 2017 a new curriculum was introduced. Reportedly important historical events and names of founders of the Republic have been replaced with Islamized ones, promoting Muslim scientist and increasing the religious content in the curriculum. ${ }^{66}$ Additionally, Karapehlivan shares how the new curriculum has introduced "15 July Victory of Democracy" as a new subject symbolizing "a new phase in the imposition of a new form of Turkishness, an Islamized version of the national identity and the creation of a pious generation, one of the AKP's key strategic projects since the party's third term in power since 2011. ${ }^{167}$ Another important element of the new curriculum he mentions is "the education of values" intended to strength national values and Islamic morality, when in reality he argues it translates into more religious and conservative content and curriculum based on a single interpretation of Sunni Islamic teaching rather than offering different perspectives. ${ }^{68}$ As this paper has discussed, these radical changes to the educational system with Islamic overtones have had a significant impact on Kurds as well as other minority groups, such as Alevis and non-Muslims. It is apparent that education under the AKP continues - although from a conservative religious ideology this time - to follow the trend of promoting a narrow, exclusive, and discriminatory vision of the Turkish nation.

66 F. Karapehlivan, Constructing a "New Turkey" through education. An overview of the education policies in Turkey under the AKP rule, "Heinrich Böll Stiftung" 2019, par. 18.

67 Ibidem.

68 Ibidem. 
Following this analysis, it is apparent that Turkey's education system has historically served as a catalyst in the intractable conflict between the Government of Turkey and the PKK specifically, and the Kurdish population more generally, and this paper argues that this continues to be the case. Furthermore, this studyhas illustrated how, despite a number of reforms and introduction of human rights, democracy, and citizenship educational courses, the education system continues to inhibit the prospects of social transformation and the establishment of a culture of peace. It is therefore apparent that Turkey's educational system is in need of peace education. As the paper formally stated, peace education can serve as a powerful tool for social transformation by challenging dominant repertoires which support a culture of conflict. Peace education can also serve as the beginning of reconciliation, which consists of mutual recognition and acceptance, mutual trust, and positive attitudes.

Before implementing peace education programs, however, an influential study by Bar-Tal and Rosen suggest that a number of conditions first have to be met. ${ }^{69}$ The following section draws exclusively from this study and reviews its recommendations in establishing peace education programs, all of which can serve as the useful framework for policy makers and educators in decisions relating to the mainstreaming of peace education in the educational system in Turkey.

69 D. Bar-Tal, Y. Rosen, Peace Education in Societies Involved in Intractable Conflicts: Direct and Indirect Models, "Review of Education Research" 2009, No. 9, Vol. 2. 


\section{Conditions for Successful Peace Education}

Bar-Tal and Rosen (2009) suggest that before implementing a peace education program, socio-political and educational conditions need to be met for mainstreaming peace education successfully. ${ }^{70}$ Concerning the socio-political conditions, their study suggests the following: 1 ) a process of peace with the rival is underway; 2 ) a large majority of society supports the peace process; 3 ) there is ripeness for reconciliation, referring to the readiness of society to hear the message of peace education which is not the same as supporting a peace process. It also refers to a society's willingness to change their worldview which includes collective memory and ethos of the conflict; and 4) peace education is formally supported by the government (i.e. the president) as a peace-orientated policy. ${ }^{71}$ Each of the four conditions outlined are thought to create the necessary social climate for the implementation of peace education. However, when all four social conditions are met, they do not assure the successful implementation of peace education in an education system.

For this reason, the Bar-Tal and Rosen outline a number of educational conditions regarded as necessary for the implementation of peace education. They include: 1) the Ministry of Education's support, since they represent the highest educational authority, and have a greater potential of rallying support of leaders and teachers; 2 ) the peace education policy is decisive and well-defined with details on how to

70 Ibidem, p. 561.

71 Ibidem. 
carry out peace education which may imply major changes to the educational system. The study therefore suggests developing a short-term and long-term educational policy, reflected in new curriculum, new textbooks, development of new programs, new training of curricula of teachers, school principals and staff; 3) peace education is backed up by authorities, which have the infrastructure and resources to implement peace education. ${ }^{72}$ They argue that implementation requires the availability of experts and professionals who can realize the institutionalization of peace education in schools. They also stress the need of constant evaluation to find out which programs are efficient.

In the event the above conditions do not exist, Bar-Tal and Rosen suggest adopting either indirect or direct models of peace education. They outline a number of themes to help educators and practitioners implement peace education programs, even in unlikely scenarios. In the case that the socio-political conditions do not allow for direct reference to the intractable conflict, they suggest using five themes relevant to peace-making, such as - reflective thinking, tolerance, ethno-empathy, human rights (those inherent in our nature and that we can't live without), and conflict resolution (the ability to solve conflicts peacefully; the understanding of conflict and assisting individuals in developing non-violent approaches. ${ }^{73}$ These themes are thought to encourage openness, criticism, scepticism, exposure to, and consideration of alternative ideas, sensitivity towards human rights, empathy towards other groups, and knowledge and skills of conflict resolution, all of which may lead to di-

72 Ibidem, p. 562.

73 Ibidem. 
rect forms of peace education in the long-run. Furthermore, they argue that they contribute towards the consolidation of democracy, and humanism, and thus should be part of every educational system. ${ }^{74}$

If, however, the conditions are ripe, Bar-Tal and Rosen suggest adopting direct peace education that deals with the following five areas concerning the culture of conflict: conflict and peace, peace process, the presentation of the rival, the history of the conflict (the formation of a new collective memory), and new emotions, all of which allows for the construction of a new ethos of peace that makes it possible for a culture of peace to evolve ${ }^{75}$ All five of these dispositions are deemed essential to peace education in the regions of intractable conflict, regarded as having a unique quality and potential contribution to the student outlook required for fostering the cognitive, attitudinal, emotional, and behavioural changes in societies engaged in intractable conflicts. $^{76}$

Each of these models is regarded as applicable in any context given that they are general and adaptable. And while the themes are constant, Bar-Tal and Rosen argue that the content, pedagogy and methods must be adapted to the particular case of educators. They emphasize that it is essential to be aware of the socio-political conditions when launching a peace education program that either will facilitate or hamper peace education. Either way they stress that peace education can flourish under any condition - including vio-

74 Ibidem, p. 564.

75 D. Bar-Tal, Y. Rosen, Peace Education in Societies Involved in Intractable Conflicts: Direct and Indirect Models, "Review of Education Research" 2009, No. 9, Vol. 2, p. 567.

76 Ibidem. 
lence - because the themes support humanism and democracy: core values shared by many societies. ${ }^{77}$

\section{Conclusion}

This paper has sought to contribute to the literature and research covering different aspects of the peace process which collapsed between the Government of Turkey and the PKK. It has identified education as an overlooked dimension in the peace process and sought to illustrate why it is vital to pay attention to the role of education for any future prospects of a new peace process. This paper discussed how education can contribute to intractable conflicts. It also considered the ways education can inhibit or enhance peace processes in countries currently in and/or emerging from violent conflicts. Specifically, this paper examined the case of Turkey, analysing the role the education system has played in the intractable conflict between the Government and the PKK. And despite several reforms and introduction of human rights, democracy, and citizenship courses, my study has illustrated how education undermined the peace process and continues to reinforce the social divisions that has served as the deepest cause of the intractable conflict, inhibiting the prospects for social transformation from a culture of conflict towards a culture of peace.

Finally, the paper examined the prospects of adopting and mainstreaming peace education as a tool for social transformation, after outlining the necessary socio-political and educational conditions needed. However, it was apparent, owing to using Bar-Tal and Rosen's framework, that Turkey has yet

77 Ibidem. 
to satisfy all four of the advised socio-political conditions. Although the Government and a large majority of society previously supported the peace process, there remains a lack of willingness to change the worldview which includes the collective memory and ethos of the conflict.

While Turkey has made positive advancements in the education reform and received support from the Ministry of Education on many education initiatives, this study has illustrated that policies adopted are often not implemented in practice. Perhaps part of the problem derives from the lack of a comprehensive educational plan, which includes both short and long-term objectives in terms of strategies to transition towards a culture of peace. As was pointed out, there also remains an inadequate number of teachers' training programs to cover new curriculum and pedagogical approaches. Turkey's education system has therefore yet to meet the necessary educational conditions for the successful mainstreaming of peace education.

Nevertheless, all hope is not lost as Turkey already has experience with peace education-based programs which have been piloted or offered as electives in primary and secondary education. Furthermore, there are currently peace education programs running at the tertiary level, such as the MA Peace and Conflict Studies program at the Social Sciences University of Ankara (previously hosted at Hacettepe University), MA in Conflict Analysis and Resolution at Sabancı University, as well as elective Peace Education courses offered to undergraduates at Kocaeli University, not to mention workshops and projects which have been supported in the past by international and regional organisations, such as the EU and UN. This paper suggests promoting these programs and initiating new ones with the backing of inter- 
national, regional, and local stakeholders. The hope is that peace education-based programs will gain momentum and endorsement that may assist in laying the foundation necessary for the mainstreaming of peace education in Turkey's education system, leading to the sustainable and long-term social transformation and creating a culture of peace.

\section{Bibliography}

Altinay A.G., The Myth of the Military-Nation: Militarism, Gender, and Education in Turkey, New York 2004.

Bar-Tal D., Rosen Y., Peace Education in Societies Involved in Intractable Conflicts: Direct and Indirect Models, "Review of Education Research" 2009, No. 9, Vol. 2.

Barkey H.J., Turkey's Kurdish Question, Lanham 1998.

Beriker-Atiyas N., The Kurdish Conflict in Turkey: Issues, Parties, and Prospects, "Security Dialogue" 1997, No. 28, Vol. 4. Bush K.D., Saltarelli D., The Two Faces of Education in Ethnic Conflict, New York 2000.

Can B., Gök F., Şimşek S., The Role of Teachers in Building Societal Peace / How is the Kurdish Issue Projected onto School?, Istanbul 2013.

Çayir K. Gürkaynak I, The State of Citizenship Education in Turkey: Past and Present, "Journal of Social Science Education” 2008, No. 6, Vol. 2.

Christofis N., The State of the Kurds in Erdoğan's 'New' Turkey, "Journal of Balkan and the Near Eastern Studies" 2019, No. 21, Vol. 3.

Danesh H.B., Towards an Integrative Theory of Peace Education, "Journal of Peace Education" 2006, No. 3, Vol. 1. Ensaroğlu Y., Turkey's Kurdish Question and the Peace Process, "Insight Turkey" 2013, No. 15, Vol. 2. 
Fitzduff M., Jean I., Peace Education: State of the Field and Lessons Learned From USIP Grantmaking, Washington DC 2011.

Fountain S., Peace Education in UNICEF, "Working Paper Series, Programme Division, Education Section” New York 1999.

Galtung, J., Peace by Peaceful Means, London 1996.

Gündoğan N.O., Kurdology in Turkey: Barometer of the "Peace Process" (Part 1), "Jadaliyya", 2.11.2020, https:// www.jadaliyya.com/Details/41947.

Gürcan A., The Problems of Religious Educatoin in Turkey: Alevi Citizen Action and the Limits of ECtHR, "Sabanc1 University IPC-Mercator Policy Brief” 2015, https:// ipc.sabanciuniv.edu/Content/Images/CKeditorImages/20200323-14031185.pdf.

Hoffman M., The State of the Turkish-Kurdish Conflict, "Center for American Progress" 2019, https://www.americanprogress.org/issues/security/reports/2019/08/12/473508/ state-turkish-kurdish-conflict/.

İnce B., Citizenship Education in Turkey: Inclusive or Exclusive, "Oxford Review of Education" 2012, No. 28, Vol. 2. Kandiyoti D., Emanet Z., Education as a Battleground: The Capture of Minds in Turkey, "Globalizations" 2017.

Karapehlivan F., Constructing a "New Turkey" through education. An overview of the education policies in Turkey under the AKP rule, "Heinrich Böll Stiftung" 2019, https://tr.boell.org/ en/2019/10/01/constructing-new-turkey-through-education.

Kaya A., Islamisation of Turkey under the AKP Rule: Empowering Family, Faith and Charity, "South European Society and Politics" 2015, No. 20, Vol. 1. 
Lindenstrauss G., Back to Square One? The Collapse of the Peace Process with the Kurds in Turkey, "Strategic Assessment" 2016, No. 18, Vol. 4.

Nurcan K., Discrimination Based on Colour, Ethnic Origin, Language, Religion and Belief in Turkey's Education System, Istanbul 2015.

Perry V., The Myth of Incremental Education Reform in BiH, "Democratization Policy Council", 3.02.2021, http:// www.democratizationpolicy.org/the-myth-of-incremental-education-reform-in-bih/.

Perry V., Keil S., The OSCE Mission in Bosnia and Herzegovina: Testing the Limits of Ownership, "Nationalities Papers: The Journal of Nationalism and Ethnicity" 2013, No. 41, Vol. 3.

Richmond O., The Transformation of Peace, Houndsmill 2007. Salomon G., Nevo B., Peace Education: The Concept, Principles, and Practices around the World, New York 2002. Savran, A., The Peace Process between Turkey and the Kurdistan Workers' Party, 2009-2015, "Journal of Balkan and Near Easter Studies” 2020, No. 22, Vol 6.

Sen A. Starkey H. Citizenship Education in Turkey: From Militant Secular to Islamic Nationalism, London 2019. Smith A., The Influence of Education on Conflict and Peace Building, "Background Paper Prepared for the Education for All Global Monitoring Report 2011: The Hidden Crisis - Armed Conflict and Education", Paris 2010.

Smith A., Vaux T., Education, Conflict, and International Development, London 2003.

Smith D. (2000), Trends and Causes of Armed Conflict, "Berghof Handbook for Conflict Transformation", Berlin 2000. Stetter S. (2020), What Foster and What Hampers Sustainable Peace Education? Policy Insights, Practical Experi- 
ences and Recommendations from Europe and Beyond, Report for the Project "Mapping Sources of Mutual Distrust in Palestinian-Israeli Relations", Munich 2020.

Tawil S., Alexandra H., Education, Conflict and Social Cohesion, Geneva 2004.

Tinker V., Peace Education as a Post-Conflict Peacebuilding Tool, "All Azimuth" 2016, No. 5, Vol. 1.

Toè R., Bosnia's Segregated Schools Perpetuate Ethnic Division, "Balkan Transitional Justice", 15.07.2016.

Tomlinson, K. and Benefield, P., Education and Conflict: Research and Research Possibilities, "National Foundation for Educational Research” 2005.

Ünal F., Comparing Human Rights and Citizenship Education in Primary Education in Turkey with International Conventions, "World Applied Sciences Journal" 2011, No. 18 , Vol. 8.

UNESCO, World Directory of Peace Research and Training Institutions, Paris 2000.

Villellas A. Turkey and the Kurdish question: Reflecting on peacebuilding, "Quaderns de Construcció de Pau 22" 2011, No. 22.

World Bank, Reshaping the Future: Education and Post-Conflict Reconstruction, Washington DC 2005.

\begin{abstract}
Hopes of ending three decades of intractable conflict which has impeded the country's modernization and democratization efforts and resolving the Kurdish Question were dashed in 2015, when the peace process collapsed and violence renewed between the Republic of Turkey, led by the Justice and Development Party (AKP) and the Kurdistan Workers' Party (PKK). Literature has covered different aspects of Turkey's peace process and identified reasons for its collapse,
\end{abstract}


but has paid scant attention to a crucial dimension - education. This paper seeks to address this overlooked and yet vital dimension by first providing the framework to understand the role of education and its peace-building or peace-destroying potential. Following this discussion, the paper turns to the case of Turkey seeking to understand the role education has historically played in the country's ongoing intractable conflict, while also taking into consideration the broader political, economic, and social context. It then examines the structural and ideological reforms of education under the AKP, arguing that they failed to adequately address the Kurdish Question and the deep-rooted causes of the intractable conflict, which consequently undermined the peace process. The study then considers the current state of Turkey's education system contending that it continues to perpetuate the intractable conflict. Finally, the paper concludes by underlining the necessity of peace education as a tool for social transformation and creating a culture of peace, outlining the socio-political and educational conditions needed to successfully integrate and mainstream it.

Keywords: Peace, Peace Process, Peace Education, Education in Turkey, Culture of Peace, Social Transformation 


\section{Kishu Daswani}

Government Law College, Mumbai and the St. Xavier's College, Mumbai

\section{The Citizenship (Amendment) Act 2019, India: A Crisis of Statelessness*}

\section{Introduction}

The controversial Citizenship (Amendment) Act, 2019, ('CAA') has been seen as exclusionary, discriminatory and plain neglectful of the considerable Muslim population that India is home to. This paper explores the tenuous ways in which it has radically changed the nature of citizenship laws in India. It then focuses on its socio-political necessity, brought about by illegal mass migration in Assam. More worryingly, the CAA introduces religion as a qualifier to Indian citizenship in an unprecedented departure from the laws hitherto formulated.

This exclusionary slant that citizenship laws have taken in India casts aspersions not only on independent India's secular roots, but also on the basis of granting citizenship as originally envisioned by the framers of the Indian Constitution. This paper considers how the CAA, accompanied by its data-collection exercise, the National Register of Citizens ('NRC') will trigger a crisis of statelessness for India's Muslims, many of whom have been living in India for decades. It

\footnotetext{
* This paper reflects the position of law as on $10^{\text {th }}$ December 2020.
} 
argues that the CAA will be used as a religio-political sieve to exclude Indian Muslims from the newly drawn boundaries of citizenship.

Part I of this paper traces India's complicated history with citizenship, contextualizing the shift in citizenship law from a predominantly jus soli conception, to a jus sanguinis application until the CAA emerges. Part II explains the introduction of the CAA as a solution for the Assam NRC, even as it introduces religion as a qualifier to citizenship. Part III illustrates how the CAA strips Indians of their rights in three principal ways: by rendering a large religious minority effectively stateless; by denying them basic human rights enshrined as Fundamental Rights in the Constitution and by disparately disadvantaging women. Part IV considers the jurisprudence of other regional courts of human rights in viewing nationality as a human right, which the CAA fails to do entirely. Part V concludes by reiterating how the CAA violates the idea of Indian secularism by introducing religion into citizenship resulting in a crisis of statelessness for Indian Muslims.

\section{Tracing the History of Citizenship in India}

Given that the Indian people gained the right to citizenship when they won their independence from colonial British rule, equality is both the premise and promise of Indian citizenship. ${ }^{1}$ Since citizenship does not exist in an unchanging static space, ${ }^{2}$ the current dilemma facing Indian citizenship

\footnotetext{
N. Jayal, Citizenship and Its Discontents, Cambridge 2013, p. 12.

2 J. Shklar, American Citizenship: The Quest for Inclusion, Cambridge 1991.
} 
today is intrinsically linked with the historical challenges of its past. The granting of citizenship in India has been commandeered by several (often conflicting) motivations. When the Republic of India first emerged, in the 1950s citizenship of India was a right of any person born in India and was granted on the jus soli principle. Starting from the 1970s, as the socio-political landscape of the country changed, the elements of jus sanguinis citizenship, or citizenship based on the basis of blood/descent began to take root as an additional requirement to the mere territorial birth of an individual seeking citizenship. Both principles are well recognized by countries internationally. The CAA upsets this justiciable balance by granting citizenship not only based on these well recognized principles, but also by introducing a previously unnecessary criterion for the granting of citizenship - RELIGION.

\section{A. The Secular Foundations of Citizenship and the Constitution}

The Constituent Assembly Debates are the evidence of the fact that secularism was infused into the very heart of the Indian Constitution. ${ }^{3}$ In the postcolonial era, secularism was not to be a copy pasted from the annals of its Western tradition; instead its practice and promotion was to account for the peculiarities of Indian life and its diverse religions. ${ }^{4}$ In the development of the standard of Indian secularism

3 Constituent Assembly Debates, 11.08.1949, Vol. IX, Part 1.

4 S. Sathe, Secularism: Law And The Constitution Of India With Special Reference To Judicial Activism (1999), [in:] Selected Works Of S.P. Sathe Volume 3: Social Justice And Legal Transformation, ed. Sathya Narayan, New Delhi 2014, pp. 117, 126. 
(entirely different from the wall of separation between State and Church adopted by its American counterpart), State intervention was deemed necessary because religions form the entire social behaviour of the Indian people, as a result of which secularism could only exist when some line was drawn between what was religious and what was temporal. ${ }^{5}$ It should come as no surprise to the unacquainted reader that the Indian State has always, and at times with good reason, been embroiled with religion, simply because social life, even after all these years is ordered this way.

India's independence from British rule on $15^{\text {th }}$ August 1947 came at the cost of partitioning the country into secular India and Islamic Pakistan (a country then with a divided land mass one to the east and one to the west of India). The birth of these two sovereign nations saw close to a million people being killed and 15 million displaced in the riots that followed the partition. ${ }^{6}$ Those times, which scarred the whole generation with traumatic memories, raised several issues. With millions of Hindus, Muslims, Sikhs displaced on either side of the western and eastern borders of the Indian sub-continent, citizenship was a contentious issue.

Indian citizenship was predominantly based on the jus soli doctrine. Citizenship would be granted to any person born in India on or after $26^{\text {th }}$ January $1950,{ }^{7}$ the date of adoption of the Constitution. When East Pakistan seceded

5 Ibidem, p. 38.

6 W. Dalrymple, 'The Great Divide: The violent legacy of Indian Partition, “The New Yorker", 22.06.2015, https://www.newyorker.com/magazine/2015/06/29/the-great-divide-books-dalrymple [access: 10.12 .2020 ].

7 Citizenship Act, 1955, s 5. It is worth noting that in 1955 the act provided that if a person was born outside India, such a person could also claim Indian citizenship if his father was an Indian citizen at the time of such birth. 
to become Bangladesh in 1971, illegal mass migration into the tiny state of Assam prompted the revision of citizenship law introducing an additional, mandatory and a much more prominent requirement of parental birth as per the jus sanguinis principle. This marked the first departure from the Constituent Assembly's notion of jus soli citizenship in 1949.

\section{B. Citizenship as a Remnant of Partition: Adhering to the Jus Soli Principle}

It is very evident from the Constituent Assembly debates of $1949^{8}$ that religion and status of parental birth were both considered and then specifically excluded as a criterion for granting citizenship. The Constituent Assembly remained staunchly impartial, but not neutral to the effect of religion on citizenship, in keeping with India's secular outlook. Parliamentarian P.S. Deshmukh's amendment proposal that all Hindus and Sikhs in the world who were not already citizens of another State should be entitled to Indian citizenship under Article 5 was resoundingly rejected by the Constituent Assembly. ${ }^{9}$

Although an individual's religion was not considered for the purpose of granting citizenship in the early days, the markers of religious differences were inadvertently sprinkled in the Constitution. Article 6 referred to 'refugees' or those migrating to India from Pakistan before July 1948, (implying Hindus) and remained largely unremarkable. Article 7 came to denote 'migrants' or those who had migrated from India

8 Constituent Assembly Debates, 11-12.08.1949, Vol. IX, Part 1.

9 Ibidem. 
to Pakistan, but subsequently returned to India under a permit of resettlement issued by the Indian government (generally implying Muslims, to the extent that Hindu or Sikh returnees were labeled non-Muslim migrants). ${ }^{10}$ Despite the ill-concealed religious identities of the displaced that shone through with the use of either refugee or migrant, citizenship was never denied or granted on the basis of religion alone. Forged documentation, property tangles and divided loyalties swayed governments and courts on either side of the border, but citizenship remained an exercise in pursuance of the jus soli principle.

\section{Unrest in Assam: Shifting Loyalties to the Jus Sanguinis Principle}

In 1949, P.S. Deshmukh also suggested the inclusion of Indian parentage as a qualifier to obtaining Indian citizenship, indicating a clear slant in favour of the jus sanguinis principle in his amendment proposal. ${ }^{11}$ As mentioned earlier, this was rejected and the Constitution proceeded to grant citizenship in accordance with the principle of jus soli. As independent India grew into a country in its own right, the allure of the jus sanguinis principle became increasingly harder to resist. Several reforms to the Citizenship Act, 1955 thereafter, cemented the jus sanguinis principle as the new basis of granting citizenship in India.

Understandably, this sort of fundamental change occurred over several decades. The conflict between the two halves of East and West Pakistan finally culminated in the

10 N. Jayal, Citizenship and Its Discontents, Cambridge 2013.

11 Constituent Assembly Debates, 11.08.1949, Vol. IX, Part 1. 
creation of independent Bangladesh on the eastern side of India. The humanitarian crisis that preceded the conflict in 1971 resulted in almost ten million refugees crossing over to India. ${ }^{12}$ Most of these migrants arrived in the tiny state of Assam in the northeastern corner of the country. The indigenous people of Assam fearing the dilution of their ethnic culture had long protested the inundation of their land by the refugees from east Pakistan (now Bangladesh).

The protests came to a head, and the Assam Accord was signed in 1985 between the Central government and the protestors. This prompted the first major restructuring of the Citizenship Act, 1955. Clause 5 of the Assam Accord classified foreigners into three distinct categories: those who had entered Assam before 1 January 1966 and would be recognised as citizens of India; those who arrived in Assam between 1 January 1966 and 24 March 1971 would be disenfranchised and required to register themselves as 'foreigners' under the Registration of Foreigners Act, 1939; and those who had entered Assam after 24 March 1971, would be declared as illegal immigrants. In this respect, the precedent of using a cut-off date, ${ }^{13}$ to determine citizenship for immigrants entering the country was introduced in Assam for the first time. A second less subtle mandatory condition, that would have certainly won P.S. Deshmukh's approval, was the requirement for those born after the respective cut-

12 J. Chatterji, Of Graveyards and Ghettos: Muslims in Partitioned West Bengal, 1947-67, [in:] Living Together Separately: Cultural India in History and Politics, eds. M. Hasan, A. Roy, India 2005, 228 as cited in H. Roy, Partitioned Lives: Migrants, Refugees and Citizens in India and Pakistan, 1947-65 "University of Dayton History Faculty Publications" 2012, Vol. 3, https://core.ac.uk/download/pdf/232825741.pdf [access: 10.12.2020].

13 Citizenship Act, 1955, s 3. 
off dates to prove that at least one of their parents was an Indian citizen at the time of their own birth. ${ }^{14}$ This marked a distinct shift to the jus sanguinis regime in Indian citizenship.

These changes in Assam are telling in the broader context of the National Register of Citizenship (NRC), a statewide census that was rejuvenated by the Assam Accord for the people of Assam specifically in 1986, and for the rest of India in 2004. ${ }^{15}$ Although the underlying objective was to stall the influx of illegal immigrants, the process of detecting and deporting foreigners was never properly enforced, culminating in a colossal litigation before the Supreme Court of India in 2015 when the process was finally expedited. ${ }^{16}$ Under the court's watchful eye, ${ }^{17}$ when the NRC was finally conducted in Assam in August 2019, 19,06,657 individuals were left off the list of citizenship. ${ }^{18}$ These 19,06,657 'noncitizens' posed a precarious problem for the central government - one that had to be resolved quickly and efficiently.

14 Citizenship Act, 1955, s 3(c)(ii).

15 A. Roy, Ambivalence of Citizenship in Assam (2016), 51(26-27) "Economic and Political Weekly", pp. 45-51.

16 Assam Sanmilita Mahasangha v. Union of India (2015), 3 SCC 1.

17 Assam Sanmilita Mahasangha v. Union of India (2019), 9 SCC 79; Assam Public Works v. Union of India, (2017) SCC Online SC 1885; Assam Public Works v. Union of India, (2018) SCC Online SC 3366; Assam Public Works v. Union of India, (2018) 9 SCC 229; Assam Public Works v. Union of India, (2018) SCC Online SC 1014; Assam Public Works v. Union of India (2019), 9 SCC 70.

18 Assam Final NRC List Released: 19,06,657 People Excluded, 3.11 crore make it to Citizenship List, "India Today", 31.08.2019, https://www. indiatoday.in/india/story/assam-final-nrc-list-out-over-19-lakh-peopleexcluded-1593769-2019-08-31 [access: 10.12.2020]. 


\section{Religion Dives into Citizenship: The Beginning of the CAA}

It was in light of the NRC exercise in Assam, and the staggering number of individuals it left off the citizenship roster, that necessitated the expeditious implementation of the CAA. The NRC itself has been deemed full of anomalies, ${ }^{19}$ which are yet to be rectified more than a year after its publication. ${ }^{20}$ Scholars theorise that the principal purpose of the NRC exercise in Assam was to strip the Bengali Muslims of the right to vote. ${ }^{21}$ Statistically speaking, disenfranchising two million people (who were expected to be only Muslims) from the broad 26 million people who reside in Assam would have added a distinctly religious flavour to citizenship requirements in the current Hindu majoritarian political scenario of the country. ${ }^{22}$ However, to the surprise of the political landlords of the 19,06,657 individuals left off the citizenship roster, not all turned out to be Muslims-indigenous people, tribal groups and many of the Gorkha people of Assam, also found themselves on the list. ${ }^{23}$ This was the greater political problem that begged instant resolution.

19 S. Tharoor, Battle of Belonging, India 2020.

20 A. Saikia, In the North East, the Citizenship Amendment Act has activated a fresh wave of Nativist Sentiment, Scroll India. India, 8.12.2020, https://scroll.in/article/979452/in-the-north-east-the-citizenship-amendment-act-has-activated-a-fresh-wave-of-nativist-sentiment [access: 10.12.2020].

21 S. Tharoor, Battle of Belonging, India 2020.

22 Ibidem.

23 G. Das, Gorkhas Excluded from NRC in Assam say they wont go to Foreigners Tribunal, “The Wire”, 25.09.2019, https://thewire.in/rights/ nrc-assam-gorkha-bgp [access: 10.12.2020]. 
The CAA effectively relaxes citizenship norms for persons belonging to six non-Muslim religious minorities (Hindus, Sikhs, Buddhists, Jains, Parsis and Christians) of three Muslim-majority countries (Pakistan, Bangladesh, Afghanistan) who may have entered India illegally before 31 December $2014 .{ }^{24}$ It enables such individuals to obtain citizenship in India, either by registration or naturalization, despite their illegal entry into the country. This is the first time in the complex history of citizenship in India that religious groups have been so specifically named in legislation-marking the certain introduction of religion as a qualifier to citizenship. The CAA thus acts as a religious-political sieve, to save the non-Muslim individuals who are unable to establish citizenship under the requirements of the NRC, while rendering Muslims on the list stateless. This exclusionary bias towards Muslim immigrants has been building up ever since the right-wing government came into power. For instance, on $15^{\text {th }}$ December 2014, five years before the CAA, long term visas were granted to Pakistani Hindus, Sikhs, Christians and Buddhists, with no mention of Muslims, Jains and Parsis. ${ }^{25}$ On $22^{\text {nd }}$ October 2018, these rules were amended to the effect that only Hindus, Sikhs, Buddhists, Jains, Parsis and Christians from Pakistan, Bangladesh and Afghanistan are eligible to apply for long term visas, excluding only Muslims.

These relaxations for certain religions to the exclusion of others are not limited to the CAA alone. For instance, the penalty for overstaying visa permits in India has been re-

24 CAA, s 2.

25 R. Chitra, P. Sinha, Before CAA, a String of Government Orders made it Impossible for Muslim Migrants to get Citizenship, "The Times of India”, 22.01.2020, https://timesofindia.indiatimes.com/india/before-caastring-of-government-orders-made-it-impossible-for-muslim-migrantsto-get-indian-citizenship/articleshow/73516606.cms [access: 10.12.2020]. 
laxed for Hindus, Sikhs, Buddhists, Jains, Parsis and Christians from Pakistan, Bangladesh and Afghanistan, while the same penalty for Muslims appears disproportionately exacerbated. ${ }^{26}$ Consider the following table. ${ }^{27}$

Table. Penalty on Non-Extension on Short Term Visa/LTV on Time

\begin{tabular}{|l|c|c|}
\hline Period of Overstay & $\begin{array}{c}\text { For Hindus, Sikhs, Buddhists, Jains, Parsis } \\
\text { and Christians }\end{array}$ & For Muslims \\
\hline $1-90$ days & INR 100 & USD 300 (INR 21,300) \\
\hline 90 days -2 years & INR 200 & USD 400 (INR 28,500) \\
\hline More than 2 years & INR 500 & USD 500 (INR 35,600) \\
\hline
\end{tabular}

Interestingly, despite the CAA's dominant object of the abating of religious persecution, ${ }^{28}$ the phrase "religious persecution" does not feature in the final text of the act. The CAA also introduces additional conditions, ${ }^{29}$ and reduces the naturalization requirements from 11 years to five years for individuals who fulfill the requirements of Section 2.30 What is even more alarming are the two most immediate consequences of introducing religion into the fold of cit-

26 S. Bagchi, India's New Visa Penalties Discriminate on Religious Lines, say Bangladesh Officials, “The Hindu”, 10.12.2019, https://www. thehindu.com/news/national/change-in-visa-penalty-irks-bangladesh/ article30260941.ece [access: 10.12.2020].

27 Ministry of Home Affairs, Long Term Visas, No. 25022/62/2020F-1, Foreigners Division, Ministry of Home Affairs, Government of India, (13 August 2020) https://www.mha.gov.in/sites/default/files/ AnnexVILongTermvisas20082020.pdf [access: 10.12.2020]; Ministry of Home Affairs, Long Term Visas, Foreigners Division, Ministry of Home Affairs, Government of India, 1 February 2018, https://www.mha.gov.in/ PDF_Other/AnnexVI_01022018.pdf [access: 10.12.2020]; Staff, Not Just CAA, Indian Banks and Visa Penalty Rules Discriminate against Foreign Muslims, “The Wire”, 21.12. 2019, https://thewire.in/government/ caa-controversy-property-bank-rules [access: 10.12.2020].

29 Citizenship Act, 1955, s 6B.

30 CAA, s 5. 
izenship via the CAA: first, the strain of burden of proof rests with the individual and second, as is the case in Assam, the disenfranchised have been lodged in detention camps.

\section{A. Elusive Proof and Documented Citizenship: No Papers, No Life}

The procedural challenge with the CAA is that in a stark reversal of Indian evidence law, the burden of proving citizenship lies with the disenfranchised and not the State alleging illegality. ${ }^{31}$ Indian citizenship law has historically expected incoming immigrants to prove their citizenship, ${ }^{32}$ so much so that when central legislation attempted to place the burden of disproving citizenship on the government, ${ }^{33}$ the Supreme Court was quick to strike it down. ${ }^{34}$ In 2006, the central government tried to work around this particular proposition of law, by deferring the question of determining citizenship to the tribunal, which would first determine if there were sufficient grounds for proceedings against a foreigner suspected not to be a citizen of India. ${ }^{35}$ The Supreme Court, however, struck down this procedure and reverted to its long held position of expecting individuals to prove citizenship. ${ }^{36}$

As mentioned earlier, the NRC in Assam led to the disenfranchisement of almost two million persons. This group of people who could not claim citizenship of India included

31 Indian Evidence Act, 1872, s 101.

32 Registration of Foreigners Act, 1939, s 4; Foreigners Act, 1946, s 9.

33 Illegal Migrants (Determination by Tribunals) Act, 1983.

34 Sarbananda Sonowal v. Union of India (Sonowal I) (2005) 5 SCC 665.

35 Foreigners (Tribunals for Assam) Order, 2006.

36 Sarbananda Sonowal v. Union of India (Sonowal II) (2007) 1 SCC 174. 
members of all communities. The application of the CAA to people who have immigrated from specified countries and belong to the specified communities would result in them getting the protection of citizenship whilst leaving the Muslim minority out. Similarly, an all India NRC would result in the disenfranchisement of a significant portion of Indians entirely. ${ }^{37}$ Many of those disenfranchised will be genuine Indian citizens who may very well land up in the excluded list merely because they do not have the necessary documents to prove their citizenship - a proposition entirely probable and distinctly possible in a country like India. This is especially so with the central government decreeing that the common documents that a typical Indian would have, such as voter identity cards, passports and even the nationwide social security documentation, the Aadhar, cannot be used to prove citizenship. ${ }^{38}$ Although those excluded in an NRC due to lack of adequate documentation would include Muslim and non-Muslim minorities, the CAA would then step in to 'save' the non-Muslim minorities. ${ }^{39}$

This ambivalence with documentation is not new in Indian citizenship. In the post-partition years of conflicted citizen-

37 G. Bhatia, A Little Brief Authority': Chief Justice Ranjan Gogoi and the Rise of the Executive Court, "Indian Constitutional Law and Philosophy”, 17.11.2019, https://indconlawphil.wordpress.com/2019/11/17/a-littlebrief-authority-chief-justice-ranjan-gogoi-and-the-rise-of-the-executivecourt/ [access: 10.12.2020].

38 S. Shakil, Aadhar, Voter ID Card, Passport, not proof of Citizenship: Government Officials, "New Indian Experss", 21.12.2019, https://www. newindianexpress.com/nation/2019/dec/21/aadhaar-voter-id-card-passport-not-proof-of-citizenship-government-officials-2079070.html [access: 10.12.2020].

39 A. Chandrachud, Secularism and the Citizenship Amendment Act, New Zealand India Research Institute for India: Seventy Years of the Republic at the University of Wellington, Victoria 2020, p. 25. 
ship, courts were often confronted with the evidentiary value of documents, and were largely sensitive to the plight of the times - the possession of a Pakistani passport did not instantly disallow Indian citizenship ${ }^{40}$ and the possession of an Indian passport was not conclusive proof of Indian citizenship. ${ }^{41}$ As a consequence, however, the relationship between documents and citizenship in India is inverse - the possession of citizenship did not necessarily enable the acquisition of documents certifying it, just as possessing the 'correct' documents was often used to authenticate claims to citizenship. ${ }^{42}$ The duty of drawing out these post-partition citizenship claims often fell to the courts. Given this predilection, scholars have pushed for judicial scrutiny over judicial deference in the context of the CAA ${ }^{43}$ simply because documentation has never been a particularly reliable measure of citizenship in India. Effectively, with the CAA-NRC in play, that portion of the Indian Muslims who do not have documents to prove citizenship will be rendered a people without land.

\section{B. Discrimination in Assam: The Disenfranchised in Detention Camps}

One of the most troubling consequences of the NRC exercise in Assam has been the incarceration of the disenfranchised in public detention camps. Records indicate that Assam has six

40 State of Andhra Pradesh v. Abdul Khader, AIR 1961 SC 1467.

41 Razia Begum \& Ors. v. State \& Ors., 2008 SCC Online Del 933.

42 N. Jayal, Citizenship and Its Discontents, Cambridge 2013, p. 71.

43 G. Bhatia, The Citizenship Amendment Act Challenge: Three Ideas, "Indian Constitutional Law and Philosophy", 21.01.2020, https:// indconlawphil.wordpress.com/2020/01/21/the-citizenship-amendmentact-challenge-three-ideas/ [access: 10.12.2020]. 
detention camps, concealed within jails making them virtually indistinguishable, with over 1,100 individuals incarcerated. ${ }^{44}$ The incarcerated languish here in squalor, often with little or no resources to pursue legal defenses, even where they may have mistakenly been declared as 'illegal migrants. ${ }^{\text {'5 }}$ In many ways, the Foreigners Tribunals that decide the fate of those who were unable to meet the citizenship requirements under the NRC in Assam, are not only short of mature and judicially trained officers, but also operate in openly hostile and arbitrary ways, following governmentally supplied targets of maximizing the number of people they must deem 'foreigners.' ${ }^{46}$

Just as the amendments to the granting of long-term visas preceded the amendments to CAA as seen earlier, in the same way, changes to the Foreigners Act, 1946 and the Passport (Entry Into India) Act, 1950, preceded the changing understanding of who constitutes a 'foreigner.' In 2015, changes made to these legislations allowed persons of the six minority communities that would later appear in the CAA - Hindus, Sikhs, Buddhists, Jains, Parsis and Christians - to enter India from Bangladesh and Pakistan without valid travel documents. ${ }^{47}$ In the present scenario, this implies that foreigners identified by

44 N. Siddiqui, Inside Assam's Detention Camps: How the Current Citizenship Crisis Disenfranchises Indians, "Economic and Political Weekly" 2020, Vol. 55 (7).

45 Ibidem.

46 H. Mander, A Flawed Process that Pleased None "The Hindu", 2.09.2019, https://www.thehindu.com/opinion/op-ed/a-flawed-processthat-pleased-none/article29317452.ece [access: 10.12.2020]; L. Verghese, and S. Naik, Caught in a Bureaucratic Web, “The Hindu”, 5.03.2020, https://www.thehindu.com/opinion/op-ed/caught-in-a-bureaucraticweb/article30983165.ece [access: 10.12.2020].

47 G. Devy, An Epistemic Change? Reading the CAA-NRC Protests, "Economic and Political Weekly" 2020, Vol. 55 (6). 
the NRC exercise in Assam who happen to be Hindus, Sikhs, Buddhists, Jains, Parsis or Christians from Bangladesh or Pakistan, cannot be thrown into detention camps as illegal immigrants, simply because exemptions have already been carved out for them. The combination of these acts goes to ensure that foreigners who remain against whom punitive action can be taken will be only from the Muslim community.

\section{Stripping People of their Rights}

The long-term fallout of the CAA-NRC is significant: first, it portends a crisis of statelessness where Indian Muslims are concerned; second, it signifies a complete disregard for human rights not only in international law, but also in the Constitution itself in which several of these human rights inhere; third, it disproportionately disadvantages women who find themselves left off the citizenship roster.

\section{A. Creating a Crisis in Statelessness}

India is not a state party to the 1955 Convention Relating to the Status of Stateless Persons, the 1961 Convention on the Reduction of Statelessness, the 1951 Convention Relating to the Status of Refugees or the 1987 Convention against Torture and Other Cruel, Inhuman or Degrading Treatment or Punishment. India's inability to pass any concrete refugee rights protection legislations leaves its overall policy wanting. ${ }^{48}$ It's recalcitrance in ratifying these conventions

48 The Protection of Refugees and Asylum Seekers Bill, 2015; the National Asylum Bill, 2015; the Asylum Bill, 2015. 
arise from an apprehension of undermining its sovereignty - justified either because the refugee protection program was always intended to be restrictive, ${ }^{49}$ or as a consequence of colonial hangover, ${ }^{50}$ or more aggressively because scholars argue that the Refugee Convention has been repeatedly violated by countries of the Global North. ${ }^{51}$

In light of the Indian concern of protecting its sovereignty, it is worthwhile to revisit the evolving notion of sovereignty as responsibility. ${ }^{52}$ By linking sovereignty to legitimacy, the notion of a constitutive human rights-based concept of popular sovereignty ${ }^{53}$ (as opposed to the traditional idea of state sovereignty) is gaining appeal in international law. ${ }^{54}$ This implies a shift of focus from the effective control of territory by the sovereign to the nature of control exercised. Of course, a more radical interpretation of this implies that sovereignty is conditional on whether the state fulfills its responsibilities or fails to accord decent treatment to the extent that if it fails to do so, it invites international intervention. ${ }^{55}$ Building on

49 J. Bhabha, Internationalist Gatekeepers: The Tension between Asylum Advocacy and Human Rights, "Harvard Human Rights Journal" 2002, pp. 155, 167.

50 M. Weiner, Rejected Peoples and Unwanted Migrants in South Asia, "Economic and Political Weekly" 1993, Vol. 134 (38).

51 B. Chimni, The Geopolitics of Refugee Studies: A View from the South, "Journal of Refugee Studies" 1998, Vol. 11 (4) pp. 447-448.

52 C. Phuong, International Protection of Internally Displaced Persons, Cambridge 2005, p. 214.

53 M. Reisman, Sovereignty and Human Rights in Contemporary International Law "American Journal of International Law" 1990, Vol. 84, pp. 866-870.

54 T. Franck, Fairness in International Law and Institutions, Oxford 1995, pp. 83-139.

55 F. Deng, Protecting the Dispossessed: A Challenge for the International Community, Washington D.C. 1993. 
the apprehension that CAA is only a fraction of the larger problem, ${ }^{56}$ the human rights context addressed below portend exactly what is to come.

\section{B. Embedding Human Rights in the Constitution of India}

The CAA is a significant erosion of the substantive equality promised under the Constitution. Interestingly, the human rights of equality, dignity, including the right to nationality are not obscure commitments made in the context of international law, but are fundamental rights enshrined in the fold of the Constitution. The Constitution promises to all people, not just citizens, equality and equal protection of the law by way of Article 14. This would imply that all persons equally placed would have equal protection of the laws A person who seeks to receive Indian citizenship under the new law must establish the following:

1) that he has been in India prior to 31 December 2014,

2) that he is either a Hindu, Buddhist, Sikh, Parsi, Jain or Christian and,

3) that he has migrated from Bangladesh, Pakistan or Afghanistan.

Though the raison d'étre of the act is to grant citizenship to the persons of the six communities who have been victims of religious persecution in the specified three Islamic nations, nowhere does it require the individual seeking citizenship to prove that he was religiously persecuted. Needless to say, this also paves the way of granting citizenship

56 A. Chandrachud, Secularism and the Citizenship Amendment Act, New Zealand India Research Institute for India: Seventy Years of the Republic at the University of Wellington, Victoria 2020. 
for economic migrants as long as they belong to the specific communities. While granting citizenship, the CAA refers to only the six non-Muslim minorities, and excludes other minorities, such as Jews, Shias, Ahmadiyas or even atheists and agnostics, who may face similar dangers in their home countries; it ignores refugees from other neighboring countries like Bhutan, Myanmar, Nepal and Sri Lanka; its cut-off date of 31 December 2014 undermines its ostensibly humanitarian objective. Indian legal scholars have not only questioned the constitutionality of the CAA according to the obvious inconsistencies, but have also acknowledged the potential damage caused by restricting the scope of the CAA to those escaping religious persecution only, as well as relaxing the naturalization time line from 11 years to five years. ${ }^{57}$ The act raises questions such as why people escaping other kinds of persecution are not covered; why only specific religions are covered; whether religious persecution has ceased in the three countries post the cutoff date; or is it that a person who has escaped religious persecution and entered India beyond this date is not meritious of the alleged benevolent cover provided by this act?

In Indian jurisprudence, for a law to pass the muster of the equality promised by Article 14 it must satisfy the test of reasonable classification: there must be intelligible differentia between the group that is meted out differential treatment, and the rest, and there must be a rational nexus between such differentia and the purpose of the legislation itself. ${ }^{58}$ A bare reading of the CAA suggests that there is no such intelligible differentia behind the inclusion of the

57 Ibidem.

58 State of West Bengal v Anwar Ali Sarkar, AIR 1952 SC 75. 
six non-Muslim minorities, and there is the exclusion of other minorities who may want to seek refuge in India as well as the specific inclusion of the three Islamic countries of Pakistan, Bangladesh and Afghanistan and the exclusion of India's other non-Muslim neighbouring countries. ${ }^{59}$ Strangely enough the act starts with the gross assumption that non-Muslims must necessarily have been persecuted in theocratic Islamist nations like Pakistan, Bangladesh and Afghanistan. Religious persecution is not a by-product of Islamic nations alone, just as religious persecution is not the sole danger refugees flee from. Interestingly enough, in an early post-partition case of citizenship for a man torn between India and Pakistan, the Supreme Court had remarked on the constitutional prescription of a date to determine citizenship, which could change the lives of ordinary people entirely. ${ }^{60}$ In this vein, when the object of the CAA itself is discriminatory, the discrimination cannot be justified on the grounds that there is a rational nexus that the legislation seeks to achieve. ${ }^{61}$

Indian constitutional jurisprudence has developed the test of manifest arbitrariness in order to shift the constitutional lens in equality claims from reasonable classification to disadvantage. ${ }^{62}$ In recent times, it has been used to

59 V. Kannan, Constitutionality of the Citizenship Amendment Act - A Rejoinder, "Indian Constitutional Law and Philosophy", 3.01.2020, https://indconlawphil.wordpress.com/2020/01/03/guest-post-the-constitutionality-of-the-citizenship-amendment-act-a-rejoinder/ [access: 10.12.2020].

60 Shabbir Hussain v State of Uttar Pradesh AIR 1952 All 257.

61 Subramanium Swamy v Central Bureau of Investigation (2014) 8 SCC 682; Deepal Sibal v Punjab University 1989 AIR 903.

62 E. P Royappa v. State of Tamil Nadu (1974) 4 SCC 3 par. 85; Indian Express Newespapers (Bombay) (P) Ltd. v. Union of India (1985) 1 SCC 641 par. 75. 
decide equality claims on the issues of homosexuality, ${ }^{63}$ and the peculiar practice of triple talaq in India, ${ }^{64}$ indicating that manifest arbitrariness is really used in instances of disparate impact and discrimination. ${ }^{65}$ One reading of the principle suggests that in order to identify disadvantage and disparate impact, constitutional courts all over the world consider whether legislations differentiate between groups according to those personal characteristics that they either have no control over or can only change at great personal cost. ${ }^{66}$ Citizenship, at least as envisioned by the CAA, falls foul of such a reading, as refugees seeking its protection have little to no control over their minority status, their countries of origin or the existence of the cutoff date.

Even for those who argue that the right to citizenship itself is not a fundamental right, and that Parliament has the power to determine the contours of Indian citizenship, ${ }^{67}$ it must be noted that such power is subject to the inherent limitations of the Constitution. Indian constitutional jurisprudence is peculiar in that no law can amend the basic

63 Navtej Singh Johar v. Union of India, Writ Petition (Criminal) No. 76 of 2018 (Nariman J).

64 Shayara Bano v. Union of India (2017) 9 SCC 1, par. 100. (J. Nariman).

65 D. Gandhi and S. Raveen, Rethinking Manifest Arbitrariness in Article 14 Part II Disparate Impact and Indirect Discrimination, "Indian Constitutional Law and Philosophy", 21.05.2020, https://indconlawphil. wordpress.com/2020/05/21/guest-post-rethinking-manifest-arbitrariness-in-article-14-part-ii-disparate-impact-and-indirect-discrimination/ [access: 10.12.2020].

66 G. Bhatia, The Citizenship Amendment Act Challenge: Three Ideas, "Indian Constitutional Law and Philosophy", 21.01.2020, https:// indconlawphil.wordpress.com/2020/01/21/the-citizenship-amendmentact-challenge-three-ideas/ [access: 10.12.2020].

67 Constitution of India, art. 11. 
structure of the Constitution. ${ }^{68}$ Secularism forms a cornerstone of this basic structure, even before it was formally enshrined in the Preamble of the Constitution. ${ }^{69}$ Indian secularism is unique in that it is not neutral to religion, but rather impartial to all religions. Political secularism, as one scholar puts it, is nothing more than a basic symmetry of treatment of different religious communities. ${ }^{70}$ Here, it is the commitment to secularism enshrined in the Indian Constitution and in Indian constitutional jurisprudence ${ }^{71}$ that ensures that the Parliament simply does not have the untrammelled power of promulgating amendments as exclusionary as the CAA. However, in the Indian constitutional system the only mechanism to enforce this inherent limitation of secularism rests with the courts, thus calling for judicial scrutiny of the constitutionality of the CAA.

\section{Holding a Mirror to Gender Rights: A Crisis in the Making}

A significantly sidelined consequence of the CAA-NRC exercise will be the disparate impact it will have on disenfranchised women in the country. Women in rural India, who are likely to be disenfranchised under the new regime, are even less likely to be able to produce official documentation

68 Keshavanada Bhartai v Union of India, 1973 4 SCC 225.

69 Constitution of India, Preamble.

70 A. Sen, The Argumentative Indian: Writings on Indian History, Culture and Identity, New York 2006.

71 S. Sathe, Secularism: Law And The Constitution Of India With Special Reference To Judicial Activism (1999), [in:] Selected Works of S.P. Sathe Volume 3: Social Justice And Legal Transformation, ed. Sathya Narayan, New Delhi 2014. 
than their male counterparts. ${ }^{72}$ As many as $87 \%$ of Indian women do not own land or property, ${ }^{73}$ making it difficult for them to procure any form of documentation, let alone meeting the complicated requirements of the NRC. The lack of literacy and agency often leave women in a lurch even without the CAA-NRC. Marriage and the consequent migration in a patriarchal system often leads to misplaced documents. Consider the shortfall of women voters in the recent 2019 general election - of the recorded 451 million women voters that should have been on the electoral rolls as per the 2011 census (projected to 2019), only 430 million women appeared according to the data released by the Election Commission. ${ }^{74}$ This meant a staggering 21 million women were never registered to vote, translating to about 38,000 missing voters from every single constituency in India. ${ }^{75}$ Data gaps like this simple statistics exist throughout the Indian bureaucratic system, which the CAA-NRC exercise systematically exploits to disadvantage women.

There arises the overwhelming urgency to balance gender inequalities even as a statelessness crisis looms overhead, simply because Indian Muslim women are at further risk as they fall into more than one disadvantaged group.

72 S. Lahiri, We are Seeing for the First Time, a Sustained Countrywide Movement led by Women, “The Wire”, 8.03.2019, https://thewire.in/ women/caa-nrc-protests-women [access: 10.12.2020].

73 D. Shandilya, Above All, Owning Property gives Abused Women the Option to Leave "The Wire", 8.03.2019, https://thewire.in/gender/ women-property-rights-womens-day [access: 10.12.2020].

74 P. Roy, 21 Million Women are denied the Right to Vote because their Names aren't on Voter's List, “The Logical Indian”, 17.04.2019, https:// thelogicalindian.com/story-feed/awareness/women-denied-vote/?infinitescroll=1 [access: 10.12 .2020$]$.

75 Ibidem. 
Citizenship, commonly understood as full membership in the community, was based on the threefold dimensions of civil, political and social rights and obligations. ${ }^{76}$ In the European context, this meant viewing these threefold dimensions of civil, political and social rights as interdependent, ${ }^{77}$ even as structural and institutional constraints limited women's political and economic agency in comparison with their male counterparts. ${ }^{78}$ Active citizenship requires material conditions that support and enable women's participation in the public and political sphere. ${ }^{79}$ For women, active citizenship requires their participation not in unobtrusive gender-neutral ways, but as women allowing for their differences to be recognised as integral and relevant to the community. ${ }^{80}$ For women to be able to do so, it is crucial for citizenship to accommodate both individual equality and collective difference. ${ }^{81}$ This is especially true for minority women, who require specific sets of rights, which recognise the historical forms in which their oppression and exclusion have been constructed. ${ }^{82}$

76 T. Marshall, Citizenship and Social Class, Cambridge 1950, pp. 8, $10-11$.

77 E. Meehan, Citizenship and the European Community, London 1993.

78 E. Tastsoglou, Dobrowolsky A. (eds.), Women, Migration and Citizenship: Making Local, National and Transnational Connections, Aldershot 2006.

79 J Pettman, Globalisation and the Gendered Politics of Citizenship, [in:] Women, Citizenship and Difference, eds. N. Yuval-Davies, P. Werbner, London 1999.

80 S. Castles, A. Davidson, Citizenship and Migration: Globalization and the Politics of Belonging, New York 2000.

81 E. Isin, P. Wood, Citizenship and Identity, London 1950.

82 W. Kremlicka, Multicultural Citizenship: A Liberal Theory of Minority Rights, Oxford 1995. 
The crisis of statelessness will affect Indian Muslim women in two stark ways - not only will it strip them of their identity entirely, but also the lack of documentation will raise the questions as to the adequacy of the data that may be available. In simpler terms, if a crisis of statelessness erupts, it may become difficult if not impossible to assist and trace the women who will be disenfranchised by the CAA-NRC.

\section{The Right to Nationality in International Law and Regional Courts}

The renowned scholar Oppenheim observes that although the conferment and deprivation of nationality is entirely within the exclusive competence of the states, the abuse of such a right gives rise to a claim in international law. ${ }^{83} \mathrm{Na}$ tionality generally refers to the legal relationship between an individual and the state, and may be closer to how the CAA seeks to deny its Indian Muslim population, while citizenship indicates the faculty to exercise political rights. ${ }^{84} \mathrm{Re}-$ gional courts of human rights have evolved different expositions of nationality as a human right that forms instructive reading in the context of CAA.

In Ochieng v. Tanzania, ${ }^{85}$ the African Court of Human and People's Rights reached the conclusion that nationality can only be deprived in accordance with international law by

83 L. Oppenheim, International Law: A Treatise, vol. 1, London 1937, p. 280.

84 D. Ruban, Nationality and Political Rights, [in:] The Changing Role of Nationality in International Law, eds. S. Forlati, A. Annoni, New York 2013, p. 117.

85 Anudo Ochieng Anudo v. United Republic of Tanzania, App. No. 012/2015, African Court on Human and Peoples' Rights, 22.08.2018. 
way of the four-pronged test of proportionality. In reaching its conclusion, the Court considered evidentiary value of allegedly false documents in a stark parallel to the overwhelming string of fabricated documents in post-partition India. In a similar case, Penessis v. Tanzania ${ }^{86}$ the Court unearthed the right of nationality as a fundamental aspect of the dignity of the human person in accordance with international law, adopting a position that went beyond its judgment in Ochieng. What remains infinitely more interesting is its understanding of the burden of proof in citizenship claims - the Court held that the burden of proof is shared and that the Court must effectively assess the circumstances with a view to establishing the facts. ${ }^{87}$ This implies that the individuals who assert a particular nationality bears the onus of proving so, but having discharged the duty prima facie, the burden shifts to the state to prove otherwise. ${ }^{88}$ This provides an interesting counter-parallel to the Indian scenario, where claims to citizenship have generally been heard before the courts of land, and not eradicated entirely in one fell swoop by national legislation. Admittedly, the reliance on the courts too is fading in light of the new regime, as scholar Gautam Bhatia observes how high courts have disaggregated multiple evidence of citizenship (with no claims to fabrication) placing an absolute burden of proving citizenship on individuals. ${ }^{89}$

86 Penessis v. United Republic of Tanzania, App. No. 013/2015, African Court on Human and Peoples' Rights, 28.11.2019.

87 Ibidem, 93, 95.

88 Ibidem, 96.

89 G. Bhatia, Proving Citizenship: Lessons from the African Court of Human and Peoples Rights, "Indian Constitutional Law and Philosophy", 25.02.2020, https://indconlawphil.wordpress.com/2020/02/25/provingcitizenship-lessons-from-the-african-court-on-human-and-peoplesrights/ [access: 10.12. 2020]. 
Moreover, regional courts have found that the denial of the right to nationality may give way to the denial of other human rights. The European Court of Human Rights, in Genovese v Malta ${ }^{90}$ albeit in the context of citizenship for a child borne of wedlock, came to the conclusion that the denial of citizenship raised may cause issues with the implementation of the underlying treaty of the European Convention on Human Rights, because of its impact on the private life of an individual, which embraced all aspects of a person's social identity. This link of citizenship with social identity retraces the earlier discussion on citizenship and is especially poignant for women in India as their identities are inextricably linked to the social markers surrounding them. In Hoti v. Croatia, ${ }^{91}$ for instance, where the European Court of Human Rights retraced nationality as a human right for a Kosovo-born national effectively rendered stateless, it reflected on the complications of the split of the former Yugoslavia before reaching its conclusions. Regional courts have also linked the right of citizenship with non-discrimination, in that there is also a general customary international law standard that prohibits the exercise of discrimination by states in determining citizenship..$^{92}$

The cultural intricacies of the cases before other regional courts of human rights distinguish them from the Indian perspective. The CAA is also baffling because it neglects an entire subset of the population rather than disadvantag-

90 Genovese v Malta, App. No. 53124/09 (ECtHR, 11.10.2011) 33-4. This case, however, did not concern a person who would otherwise be stateless.

91 Hoti v. Croatia, App. No. 63311/14, EctHR, 26.04.2018.

92 S. Forleti, Nationality as a Human Right, [in:] The Changing Role of Nationality in International Law, eds. S. Forlati, A. Annoni, New York 2013, p. 25. 
ing individuals. Yet international law recognizes that when the deprivation of nationality is pursued on the grounds of religion or ethnicity it can possibly amount to persecution under refugee laws. ${ }^{93}$ The CAA thus destroys the right to nationality as envisioned in an international context, on a far more alarming and large-scale level.

\section{Concluding Remarks}

The paradox of the CAA lies in the fact that although it was purportedly enacted to save non-Muslim religious minorities from religious persecution in Muslim-majority countries, it instantly becomes a persecutory legislation for Indian Muslims. It presents a precarious challenge to both national and international law. At the national level, it indicates a turn that citizenship law has never taken before in India, that remains for all intents and purposes manifestly against the secular spirit and the basic structure of the Constitution. At the international level, it is likely to trigger a crisis of statelessness as has never been seen before if the Assam NRC is replicated at the pan-India level. Undoubtedly, the degree of this sort of religious discrimination has not escaped international scrutiny: lawmakers of 'S \& D Group' of the European Parliament have drafted a scathing resolution against the CAA, calling it capable of triggering the largest statelessness crisis in the world. ${ }^{94}$

93 Haile v. Holder, Attorney General, 591 F.3d 572, United States Court of Appeals for the Seventh Circuit, 6.01.2010, pp. 4-5.

94 M. Jay, 154 European Union lawmakers draft Stunning Anti-CAA Resolution, "National Herald India", 25.01.2020, https://www.nationalheraldindia.com/india/154-european-union-lawmakers-draft-stunning-anti-caa-resolution [access: 10.12.2020]. 
The CAA also raises its own concerns of majoritarianism when it comes to its actual implementation in India. It looks increasingly likely that the CAA shall be used as a religiouspolitical sieve to flush out Muslims from their non-Muslim counterparts from the lot of the disenfranchised who are left off the NRC roster of citizenship.

The cause for alarm is not just in the intended short-term and long-term consequences of the CAA, but in just how unprecedented a crisis it is about to unfurl. If a significant section of the Indian Muslims are indeed disenfranchised, the true impulse of the crisis promises to be far more divisive and discriminatory than it appears to be at the moment. No country will be willing to accept the disenfranchised population and their only visible future will be the detention camps which will naturally result in a new ecosystem of human rights abuse. In any case, there are enough red flags at both the national and international level to indicate that the CAA is both flagrantly unconstitutional, and shockingly violative of human rights. Its implementation would leave several Indian Muslims as a stateless people without land.

\section{Bibliography}

\section{Books}

Castles S., Davidson A., Citizenship and Migration: Globalization and the Politics of Belonging, New York 2000.

Chandrachud A., Republic of Religion: The Rise and Fall of Colonial Secularism in India, India 2020.

Chatterji J., Of Graveyards and Ghettos: Muslims in Partitioned West Bengal, 1947-67, [in:] Living Together Separately: Cul- 
tural India in History and Politics, eds. M. Hasan, A. Roy, India 2005.

Forleti S., Nationality as a Human Right, [in:] The Changing Role of Nationality in International Law, eds. S. Forlati, A. Annoni, New York 2013.

Franck T., Fairness in International Law and Institutions, Oxford 1995.

Isin E., Wood P., Citizenship and Identity, London 1950.

Jayal N., Citizenship and Its Discontents, Cambridge 2013.

Kremlicka W., Multicultural Citizenship: A Liberal Theory of Minority Rights, Oxford 1995.

Marshall T., Citizenship and Social Class, Cambridge 1950.

Meehan E., Citizenship and the European Community, London 1993.

Oppenheim L., International Law: A Treatise, Vol. 1, London 1937.

Pettman J., Globalisation and the Gendered Politics of Citizenship, [in:] Women, Citizenship and Difference, eds. N. Yuval-Davies, P. Werbner, London 1999.

Phuong C., International Protection of Internally Displaced Persons, Cambridge 2005.

Ruban D., Nationality and Political Rights, [in:] The Changing Role of Nationality in International Law, eds. S. Forlati, A. Annoni, New York 2013.

Sathe S., Secularism: Law And The Constitution Of India With Special Reference To Judicial Activism (1999), [in:] Selected Works Of S.P. Sathe Volume 3: Social Justice And Legal Transformation, ed. Sathya Narayan, New Delhi 2014.

Sen A., The Argumentative Indian: Writings on Indian History, "Culture and Identity" New York 2006.

Shklar J., American Citizenship: The Quest for Inclusion, Cambridge 1991. 
Tastsoglou E., Dobrowolsky A. (eds.), Women, Migration and Citizenship: Making Local, National and Transnational Connections, Aldershot 2006.

Tharoor S., Battle of Belonging, India 2020.

\section{Journal Articles}

Bhabha J., Internationalist Gatekeepers: The Tension between Asylum Advocacy and Human Rights, "Harvard Human Rights Journal" 2002.

Chandrachud A., Secularism and the Citizenship Amendment Act, New Zealand India Research Institute for India: Seventy Years of the Republic at the University of Wellington, Victoria 2020.

Chimni B., The Geopolitics of Refugee Studies: A View from the South, "Journal of Refugee Studies" 1998, Vol. 11 (4).

Devy G., An Epistemic Change? Reading the CAA-NRC Protests, "Economic and Political Weekly" 2020, Vol. 55 (6).

Reisman M., Sovereignty and Human Rights in Contemporary International Law "American Journal of International Law" 1990, Vol. 84.

Roy A., Ambivalence of Citizenship in Assam, "Economic and Political Weekly" 2016, Vol. 51.

Siddiqui N., Inside Assam's Detention Camps: How the Current Citizenship Crisis Disenfranchises Indians, "Economic and Political Weekly" 2020, Vol. 55 (7).

Weiner W., Rejected Peoples and Unwanted Migrants in South Asia, "Economic and Political Weekly" 1993, Vol. 134 (38).

\section{Online Resources}

Assam Final NRC List Released: 19,06,657 People Excluded, 3.11 crore make it to Citizenship List, "India Today", 
31.08.2019, https://www.indiatoday.in/india/story/assamfinal-nrc-list-out-over-19-lakh-people-excluded-1593 769-2019-08-31.

Bagchi S., India's New Visa Penalties Discriminate on Religious Lines, say Bangladesh Officials, "The Hindu", 10.12.2019, https://www.thehindu.com/news/national/ change-in-visa-penalty-irks-bangladesh/article30260941. ece.

Bhatia G., A Little Brief Authority': Chief Justice Ranjan Gogoi and the Rise of the Executive Court, "Indian Constitutional Law and Philosophy", 17.11.2019, https:// indconlawphil.wordpress.com/2019/11/17/a-littlebrief-authority-chief-justice-ranjan-gogoi-and-the-riseof-the-executive-court/.

Bhatia G., Proving Citizenship: Lessons from the African Court of Human and Peoples Rights, "Indian Constitutional Law and Philosophy", 25.02.2020, https://indconlawphil.wordpress.com/2020/02/25/proving-citizenship-lessons-from-the-african-court-on-human-andpeoples-rights/.

Bhatia G., The Citizenship Amendment Act Challenge: Three Ideas, "Indian Constitutional Law and Philosophy", 21.01.2020, https://indconlawphil.wordpress.com/2020/ $01 / 21 /$ the-citizenship-amendment-act-challenge-threeideas/.

Chitra R., Sinha P., Before CAA, a String of Government Orders made it Impossible for Muslim Migrants to get Citizenship, “The Times of India”, 22.01.2020, https:// timesofindia.indiatimes.com/india/before-caa-string-ofgovernment-orders-made-it-impossible-for-muslim-migrants-to-get-indian-citizenship/articleshow/73516606. cms. 
Dalrymple W., The Great Divide: The violent legacy of Indian Partition, “The New Yorker”, 22.06.2015, https:// www.newyorker.com/magazine/2015/06/29/the-greatdivide-books-dalrymple.

Das G., Gorkhas Excluded from NRC in Assam say they wont go to Foreigners Tribunal, "The Wire”, 25.09.2019, https:// thewire.in/rights/nrc-assam-gorkha-bgp.

Gandhi D., Raveen S., Rethinking Manifest Arbitrariness in Article 14 Part II Disparate Impact and Indirect Discrimination, "Indian Constitutional Law and Philosophy", 21.05.2020, https://ind conlawphil.wordpress. com/2020/05/21/guest-post-rethinking-manifest-arbitrariness-in-article-14-part-ii-disparate-impact-and-indirectdiscrimination/.

Jay M., 154 European Union lawmakers draft Stunning Anti-CAA Resolution, "National Herald India", 25.01.2020, https://www.nationalheraldindia.com/india/154-european-union-lawmakers-draft-stunning-anti-caa-resolution. Kannan V., Constitutionality of the Citizenship Amendment Act - A Rejoinder. "Indian Constitutional Law and Philosophy”, 3.01.2020, https://indconlawphil.wordpress. com/2020/01/03/guest-post-the-constitutionality-ofthe-citizenship-amendment-act-a-rejoinder/.

Lahiri S., We are Seeing for the First Time, a Sustained Countrywide Movement led by Women, “The Wire”, 8.03.2019, https://thewire.in/women/caa-nrc-protests-women.

Mander H., A Flawed Process that Pleased None, "The Hindu", 2.09.2019, https://www.thehindu.com/opinion/oped/a-flawed-process-that-pleased-none/article29317452. ece.

Roy H., Partitioned Lives: Migrants, Refugees and Citizens in India and Pakistan, 1947-65, "University of Dayton 
History Faculty Publications" 2012, 3, https://core.ac.uk/ download/pdf/232825741.pdf.

Roy P., 21 Million Women are denied the Right to Vote because their Names aren't on Voter's List, "The Logical Indian", 17.04.2019, https://thelogicalindian.com/story-feed/ awareness/women-denied-vote/?infinitescroll $=1$.

Saikia A., In the North East, the Citizenship Amendment Act has activated a fresh wave of Nativist Sentiment, "Scroll India", 8.12.2020, https://scroll.in/article/979452/in-thenorth-east-the-citizenship-amendment-act-has-activated-a-fresh-wave-of-nativist-sentiment.

Shakil S., Aadhar, Voter ID Card, Passport, not proof of Citizenship: Government Officials, "New Indian Experss", 21.12.2019, https://www.newindianexpress.com/nation/2019/dec/21/aadhaar-voter-id-card-passport-notproof-of-citizenship-government-officials-2079070.html. Shandilya D., Above All, Owning Property gives Abused Women the Option to Leave "The Wire", 8.03.2019, https:// thewire.in/gender/women-property-rights-womens-day. Verghese L., Naik S., Caught in a Bureaucratic Web "The Hindu", 5.03.2020, https://www.thehindu.com/opinion/ op-ed/caught-in-a-bureaucratic-web/article30983165.ece.

\footnotetext{
Abstract

In theory, India is a secular democracy. ${ }^{95}$ In practice, it is becoming decidedly less so. The controversial Citizenship (Amendment) Act, $2019^{96}$ enacted by the right-wing government has been seen as

95 A. Chandrachud, Republic of Religion: The Rise and Fall of Colonial Secularism in India, India 2020.

96 Citizenship (Amendment) Act, 2019 (hereinafter 'CAA'). Notified to be in effect from $10^{\text {th }}$ January 2020.
} 
exclusionary, discriminatory and plain neglectful of the considerable Muslim population that India is home to. This paper explores the tenuous ways in which it has radically changed the nature of citizenship laws in India. It then focuses on its socio-political necessity, brought about by illegal mass migration in Assam. More worryingly, the CAA introduces religion as a qualifier to Indian citizenship in an unprecedented departure from the laws hitherto formulated.

This exclusionary slant that citizenship laws have taken in India casts aspersions not only on independent India's secular roots, but also because of granting citizenship as originally envisioned by the framers of the Indian Constitution. This paper considers how the CAA, accompanied by its data-collection unit, the National Register of Citizens ('NRC'), will trigger a crisis of statelessness for a certain sector of India's Muslims, many of whom have been living in India for decades. It argues that the CAA will be used as a religious-political sieve to exclude Indian Muslims from the newly drawn boundaries of citizenship.

Keywords: Citizenship, statelessness, human rights, nationality, India, religion, and secularism 


\section{Dickson Ogbonnaya Igwe}

National Open University of Nigeria

\section{Conflict of Interests and Demilitarisation Process against Insurgency in sub-Saharan Africa}

\section{Introduction}

For the purposes of this paper, a militarized society has one or more of the following characteristics:

- The military controls or strongly influences government policies and actions;

- There is a strong military ethos and military ideals are dominant;

- Security is viewed as fundamentally a military matter and military imperatives dominate the security agenda;

- The use of force or the threat to use force is high on the list of possible responses to any disputes which may arise.

To demonstrate the above points is a Nigerian scenario that point to militarised contexts and the consequences. The dreaded terrorists group Boko Haram also known as jama, atulahlus Sunnah Lidda, awatiwal jihad has unleashed terror in many parts of Nigeria, particularly the north eastern parts. In these northern parts, Adamawa state which happens to be very close to the Boko Haram's den of Sam- 
bisa forest suffered heavily, about seven local government areas of the state such as Madagali, Michika, Mubi north and south, Maiha, Gombi and Hong local governments fell under the occupation of the terror group. The occupation of the seven local government areas was not without social and economic meltdown, leading to breach or dislocation of intergroup relations, security, and losses of lives and property running to millions of Naira. Boko Haram expanded terror activities to all corners of northern Nigeria, not only in Hong. They bombed churches, mosques and motor parks; raided banks, police stations and prison yards. They conducted targeted assassinations of law enforcement agents as well as Christian and Muslim clerics; extort money and kidnapped people for ransom, burnt down schools and public buildings; abducted school girls and murdered school boys; and targeted foreign construction workers and medical personnel for kidnapping and murder ${ }^{1}$.

\section{Statement of Problem}

The choice of militarisation ${ }^{2}$ of the north-eastern Nigerian state involving Nigerian and regional forces to subdue violent Boko Haram insurgency affecting the area has created mix reaction and a lot of untold hardship ${ }^{3}$ accelerating underdevelopments in the area. Researchers have written articles on the

1 I. Mantzikos, "A report on the Boko-Haram attacks in Nigeria and neighboring countries: A chronology of attacks": perspectives on terrorism, 8.12.2014.

2 P.J. Peter, The Dangerous 'Pragmatism' of Al-Qaeda in the Islamic Maghreb, "Journal of the Middle East and Africa” 2012, Vol. 2, p. 1.

3 A. Salkida, Counting the cost of Boko Haram crisis, http:// desertherald.com/counting-the-cost of Boko Haram-Crisis/ [access: 9.11.2018]. 
activities of Boko Haram and military expenditure therein as there affect the social, economic, political, and religious relations of the people in the areas occupied by the Boko Haram ${ }^{4}$ but there is no or less available research works conducted on the possibility of demilitarisation using human security strategy effects to regain public confidence in the system to discourage insurgency and accelerate the socio economic life of many communities that experienced firsthand atrocities by the terrorists group, and that void is what this study intends to fill. To identify the socio-economic effects of militarisation against Boko Haram insurgency in Nigeria, cluster sampling is used where online opinion poll is conducted in areas assumed to suffer the brunt of the insurgents acts much, areas such as Chibock, Mubi, Biu, Garaha, Mararaban-Mubi and Hong town were respectively selected.

The central point of this article is that there are alternatives which are far more cost effective than the current military approach to security in most African security architecture. The adoption of such alternatives would allow some degree of demilitarization to occur. Demilitarization, then, first means a significant and sustained reduction in the power and influence of the military indicated by reductions in military expenditure, military personnel and force projection. Force projection refers to the effectiveness or capacity of a military which, it should be noted, could increase at the same time as personnel numbers fall, if men are replaced by heavy weapons 5 . Second, demilitarization is a process of

4 W. Morgan, Number of Nigerians displaced by Boko-Haram increases to 2.1 million, www.ibtimes.com/ international-organisationfor-migration2083797 [access: 9.04.2017].

5 D.G. Pruitt, J.Z. Rubin, Social Conflict: Escalation, Stalemate, and Settlement, New York 1986, p. 213. 
working towards a society which emphasizes the nonviolent resolution of conflicts, human development, personal and social justice.

\section{Literature Review}

\section{Levels and trends of militarization since 1990}

Military expenditure (milex) in the 44 or so sub-Saharan African (SSA) countries fell in real terms by 30.5 per cent between 1990 and 1999. As a proportion of GDP, this amounted to an un-weighted average of 3.0 per cent in 1990 and 2.6 per cent in $1998^{6}$. As a proportion of central government expenditure (CGE), the un-weighted means were 11.8 per cent (median 8.6) in 1990 and 8.5 per cent (median 6.8) in the late 1990s.

Full-time members of the armed forces of SSA totaled 958,500 in 1985 and 1,455,000 in 1999. In 1999, there were also some 3000,000 reservists and $238,10 \mathrm{C}$ in paramilitaries ${ }^{7}$ (IISS 2000). According to the Bonn International Centre for Conversion's (BICC) Conversion Survey 2000, military personnel in SSA countries fell by 17 per cent between 1990 and 1998 to 1.2 million. In terms of force projection, the number of heavy weapons (armored vehicles, artillery, combat aircraft, and major fight ships) fell by 35 per cent between 1990 and 1998 to 11,500 .

It might be tempting to interpret these figures as representing significant demilitarization during the 1990s. However, the changes were concentrated in particular countries.

6 Stockholm International Peace Research Institute, Military expenditure, "SIPRI. Yearbook 2000" 2000.

7 International Institute for Security Studies, The military balance 2000/2001, IISS, London 2000. 
Milex reduction in South Africa and Ethiopia exceed the total SSA reduction. Almost 70 per cent of the reduction in heavy weapons was made by South Africa, Angola and Ethiopia. And Ethiopia's reduction in military personnel exceeded the figure for the whole region. South Africa, it might be noted, has begun a major military expansion since late 1999. There is little evidence, then, of any purposeful or sustained demilitarization in SSA, even though the trends seem to be in the right direction. The financial and other resources allocated to the military are logically distinct from war and its broader costs to society.

According to the Stockholm International Peace Research Institute (SIPRI) definition, there were 10 major armed conflicts' in SSA during 1990 and 1991'; this number fell progressively to three in 1996 but then rose to 10 in 1998 and 1999. Most of these involved a struggle for the control of government and very few occurred between countries ${ }^{9}$. More pessimistically, the International Institute for Strategic Studies reported that 'armed conflict of some form' occurred in three quarters of SSA countries in the year ending August, 2000. 'battle -related deaths', which include civilians as well as military personnel, were estimated at less than 20,000 in each of 1997 and 1998, and around 75,000 in 1999, of which 45,000 occurred in Ethiopia/Eritrea. These figures, it should be noted, are modest compared with potential deaths of the 30 million or so Africans infected with HIV/AIDS. It should be noted, however, that many more civilians die from famine and disease which occur and /or go untreated as a result of

8 International Institute for Security Studies, The military balance 2000/2001, London 2000.

9 Stockholm International Peace Research Institute, Military expenditure, SIPRI Yearbook 2000, Oxford 2000. 
war. One estimate puts the number of war - related deaths in the DRC between 1988 and 2001 at 2.5 million $^{10}$.

\section{The potential benefits of the military}

A military has potential benefits to its society and a list of these is presented in Table 1 there is no doubt that these benefits have occurred in some countries at some periods of time and that it is possible to organize a military in ways which increase such benefits. The fundamental benefit which justifies the maintenance of a military force is security from external attack; the other tasks which it may perform must be regarded as non-core functions. It is possible to argue an opposite case for many of these potential benefits, particularly numbers 2, 3 and 4. Benefits 5-10 inclusive are subject to a different question. The military may indeed provide jobs, encourage modernization and so on but it may do so at a high cost and/or at a lower level of effectiveness than some alternative approach. This simply because "Might make war". The importance of comparing the cost effectiveness of the military in achieving such benefits with that of alternative ways of achieving them is a key concern to scholarship.

\section{Theoretical Framework}

Human Security Theory simply posit that since sustainable development is inevitable to guarantee sustainable security, zero conflict and war, policy thrust must focus on human capital, capability and capacity that unleash potentials for

10 International Rescue Committee, Mortality study, eastern Democratic Republic of Congo, www.their.Org/mortality/cfm [access: 9.03.2002]. 
sustainable creativity, innovation and social capital ${ }^{11}$. This theory contrast Might Make War theory (MMW), in this context, reflects the militarization approach fast becoming obsolete, ineffective and capital intensive as opposed to human security approach. As a framework to this article, MMW is a derivative of power cannon "power corrupt but absolute power corrupt absolutely" It postulates that the realization of might by a group or individual compels its exercise if not to test it, it will be to sustain it or even to expand it and all these interfere with peacebuilding process and social harmony ${ }^{12}$. This contrasts the emerging human security paradigm suggesting human capital development and empowerment as more innovative security option that discourage conflict and accelerates coexistence, peace and progress.

However, to a large extent, the military is the power house of any sovereign state. It has in principle, the monopoly of formal coercion. Exercise of might by the military whether to contain external aggression or internal conflict is considered legitimate. This is not withstanding any moral persuasion from culture in society. Products of military might easily and regularly contravene cultural nuances and prescriptions generating basis for war between formal and informal establishments.

The insistence of societies to domesticate military might as a product of society that also funds it has created space for antagonism, mistrust, fear, power thirsty godfatherism, gunrunning, blotted cost of governance, ethnicity, corruption

11 L.J. Siegel, Criminology: Theories, Pattern and Typoligies, $11^{\text {th }}$ ed. Belmont, CA: Wadsworth Cengage Learning.-states, 19.08.2007.

12 D.O. Igwe, L.A., Abubakar, Gender and Peace Process in Nigerian Security Architecture, "African Journal for Security and Development" 2019, Vol. 2, No. 4, pp. 97-109. 
and political brigandage. To this end, several reasons have been proffered as to why militarisation is a desirable social phenomenon.

\section{Seven reasons for demilitarization in SSA}

\section{The nature of warfare has changed}

Almost all armed conflicts now occur within countries rather than between them, typically between government forces and groups wishing to secede or take over government. This categorization does not do justice to the diversity which is characteristic of recent armed conflicts within sub-Saharan African (SSA) countries as manifest is some of the Africa's new wars ${ }^{13}$. These armed conflicts involve militias, armed civilians, and guerrillas as well as regular soldiers; small arms are the major cause of battle deaths; and as many as 90 per cent of casualties are civilians, who die largely from the hunger and disease which occur as a result. One implication of this is that official milex data, by reporting central government expenditure only, usually underestimates the share of national resources being allocated to military activities.

Mention should be made of the deterrent effect of military forces which underpins the first three benefits. Undoubtedly, the presence of strong military forces has, at certain times and places deterred a potential aggressor from attacking. The most often cited evidence is the 'long postwar peace' between the US and the USSR where the possession nuclear arsenals,

13 D.O. Igwe, Social Conflict, Security and Peace Building in the Information Communication Age, "Chorzowskie Studia Polityczne Journal" 2013, Vol. 6, No. 1, pp. 247-260. 
it is argued, restrained each side because of the fearful consequences of nuclear war. There are, however, strong reasons to believe that such a belief is too simplistic. That is the possession of nuclear arsenals may have played little or no part in the absence of war. As Robert Johansen argues, 'the historical evidence does not support the notion that either of the two superpowers intended deliberate, large-scale military aggression' ${ }^{14}$. More broadly, he found few pacifying or stabilizing consequences from continued military preparations, especially in the longer term. Johansen concluded that 'military buildups' decrease international security because they underpin and legitimize an obsolescent, war-prone international system.' For a devastating critique of nuclear deterrence by the former head of US air force and naval forces between 1991 and 1994, see Butler ${ }^{15}$.

\section{The meaning of security has changed}

Related to the changed nature of wars, the traditional definition of security-focusing on protection against external military threats to nation states - has become increasingly less relevant. Proponents of a new way of thinking about security suggest that the type and source of threats now facing developing countries are much wider and more complex. For example, the United Nations Development Programme argues for a redefinition which focuses on human security, under which it identifies seven aspects - economic, food,

14 J. Robert, Do preparations for war increase or decrease international security?, [in:] The long postwar peace, ed. C. Kegley, Harper Collins 1991.

15 L. Butler, The false god of nuclear deterrence, „Global Dialogue” 1999, Vol., 1, No. 2, pp. 74-81. 
health, environmental, personal, community and political security ${ }^{16}$. It estimates that a person in a developing country is 33 times more likely to die as a result of structural violence or 'social neglect' (e.g. preventable disease and malnutrition) than as a result of an inter-country war. Our way of thinking about security, then needs to move from an emphasis on territorial security based on a strong military towards broader human security, based on improving levels of human development.

\section{Military expenditure retards economic growth and development}

The key question for the economist is the net effect of milex on economic growth. Early research on the relationship between military expenditure and economic growth in developing countries led ${ }^{17}$ to conclude that military expenditure promoted economic growth, principally by enhancing human capital. Benoit's methods were too simple to handle a relationship as complex as that between milex and economic growth. Subsequent research, of increasing econometric sophistication, has almost always reached the opposite conclusion. In economic terms, military expenditure has no value:

Whatever else can be said for it, military activity does not grow food, it does not produce clothing, it does not produce clothing, it does not build housing, and it does not

16 United Nations Development Programme, Annual, Human Development Report, New York, 1994.

17 E, Benoit, Growth and defense in developing countries, „Economic Development and cultural change" 1978, Vol. 26, No. 2, pp. 271-280. 
keep people amused? Nor does it create the kind of machinery, equipment and facilities that can be used to \{produce such goods and services\}. Military activity may have other kinds of value, but it has no economic value because it does not directly contribute to material wellbeing ${ }^{18}$.

Milex does not provide a stream of returns in the future, as does government expenditure on education, health and infrastructure. As such, it reduces government saving and thereby reduces the resources available for government investment; economic growth is thus retarded. This negative effect is generally so large as to completely overwhelm any positive effects. For an extensive review of the research on this issue.

A related question is whether high military expenditure encourages private investment - both domestic and foreign - or retards it. Presumably, if investors perceive a strong military as producing a stabilizing or growth-enhancing influence on the economy, thus making high returns more likely, high milex will encourage investment. Alternatively, they may view the military as a stabilizing influence and likely to engage in coups, in which case they will invest elsewhere. As a generalization, the level of milex appears to have no significant effect on private investment in SSA; other determinants are much more important.

A second way in which military expenditure may negatively affect economic growth is via government expenditure tradeoffs. Whilst studies have often been inconclusive, it is obvious that military expenditure has opportunity costs and may constrain more productive government expendi-

18 J. Dumas, The role of demilitarization in promoting democracy and prosperity in Africa, [in:] Arming the South, eds. J. Breuer, J. Dunne, London 2002, pp. 15-33. 
tures. A third way in which military expenditure may hinder economic growth is via debt. In the 1970s and 1980s, military imports by developing countries were the equivalent of a quarter of new foreign debt incurred.

Economic growth is generally accepted as making development (and the opposite side of the coin, poverty reduction) easier to achieve, but it is clearly not a sufficient condition for development. Economic growth is a means to an end, the end being development or poverty reduction. There are two main views concerning the most effective way of reducing poverty. The current orthodoxy is to encourage economic growth by minimizing government involvement in the economy and maximizing the role of the private sector.

While the initial beneficiaries will be business people, benefits are expected to permeate throughout society and thus reduce absolute poverty. The opposite view, with links to the 'basic needs' needs' approach of the 1970s is based on the belief that even rapid growth may make little or no difference to the lives of the poor. This approach favours the direct provision of basic goods and services to low income people. Government expenditure choices - on basic consumption goods and services or on expenditures like education with long term investment effects - are therefore crucial $^{19}$.

Military expenditure works against both approaches to poverty reduction. As we have seen, it has a negative effect on economic growth via reduced savings and it leaves fewer financial resources for a government to directly meet the needs of the poor. Insofar as it hinders government from

19 D.O. Igwe, Inclusive Education and Criminality: A Challenge to the National Open University of Nigeria, „Chorzowskie Studia Polityczne Journal” 2014, Vol. 8, No. 1, pp. 219-235. 
tackling poverty, it may increase the potential for internal insecurity.

If war breaks out, the effect on countries' economies can be huge. The war of 1980-1988 is estimated to have cost Iran some \$US622 billion and Iraq some \$US352 billion which were the equivalent of nine and ten year worth of GDP respectively. The Sri Lankan civil war was estimated to have cost half a percentage point of economic growth (about 10 per cent less than otherwise) per annum between 1983 and $1922^{20}$. For a comprehensive review of the links between armed conflict and poverty in SSA, see Luckham et $\mathrm{al}^{21}$.

Finally, the military uses resources, both human and physical, which would have positive social rates of return in other uses. These include skilled labour and land. In late 1999, for example, the South African National Defense Force controlled almost 500,000 ha of state land, or about 0.4 per cent of the country's land area ${ }^{22}$.

\section{The military negatively affects human rights}

The first way in which the military affects human rights relates to its negative effects on development, as just discussed. In the words of Scheetz, "In the name of self-determination

20 G. Harris, The incompatibility of peacemaking and military power, „South African Journal of International Affairs” 2001, Vol. 8, No. 1, pp. 67-74.

21 R. Lukham, I. Ahmed, R. Muggah, S. White, conflict and poverty in Sub-Saharan Africa: an assessment of issues and evidence, „Institute of Development Studies" 2001 No. 128.

22 P. Batchelor, J. Cock, P. Mckenzie, conversion South Africa in the 1990s: defense downsizing and human development challenges, Group for Environmental Monitoring and Bonn International Centre for Conversion, Johannesburg-Bonn, 2000. 
and liberty, an astounding quantity of military weapon systems have been purchased around the world yet these military expenditures consistently impede economic development"23. These nations appear to be denying their people basic economic rights in the name of military preparedness to protect the right to self-determination and freedom.

Second, there is the opposite side of the coin to benefit, where government may use the military, or the military may take it on themselves, to attack those perceived to be opponents of the government. Of the many examples which could be cited are two recent events in Nigeria reported ${ }^{24}$ by Human Rights Watch. The first occurred in Novembers, 1999 in Bayelsa State following the murder of 12 policemen. Soldiers razed the entire town of Odi and killed as many as 2,000 civilians. No member of the military has been prosecuted for their participation in this action.

The second and similar incident occurred in Benue State and followed the killing of 19 soldiers in the area. More than 200 civilians were massacred ${ }^{25}$ in what Human Rights Watch describes as 'a well-planned military operation' carried out as a reprisal against members of the same ethnic group as those alleged to have killed the soldiers several weeks before. There has been no action against the soldiers responsible or any a strong condemnation of the killings. The Nigerian President's initial comment was that this was the sort

23 T. Scheetz, military expenditure and development in Latin America, [in:] Arming the south, eds. J. Breuer, J. Dunne, London 2002, pp. 51-70 .

24 Human Rights Watch, The destruction of Idi and rape in Choba, December 22, 1999, HRW background report, www.Hrw.org/press/1999 [access: 4.02.2002].

25 Human Rights Watch, Military revenge in Benue: a population under attack, http://hrw.org/reports2002 [access: 4.02.2002]. 
of response which could be expected from soldiers and that they may have been acting in self defense. An enquiry was subsequently set up but its remit is vague and does not include any specific reference to the massacres by the military. The military had not withdrawn from the area by February, 2002 and were involved in the systematic harassment and humiliation of local people.

\section{The effectiveness of the military}

The military is often effective, in the short term, in winning wars but this normally does little to deal with the underlying reasons for the conflict, thus resulting in a likelihood of renewed warfare. In the words of Joan Bondurant, 'violent combat... Has a strikingly low efficiency rating'. Consider four of the major international wars fought over the past two decades - the Iran-Iraq war of $1980-1988^{26}$, the UKArgentine war over the Falklands (1980), the US-Led actions against Iraq following the invasion of Kuwait (1991) and the NATO involvement in Kosovo (1999). The first ended in a stalemate after 500,000 military deaths. Military victories were won in the other three but 'peace' is maintained only by maintaining large and extremely costly military forces in each region.

Ury et al compare three common ways of dealing with disputes - by power, rights and reconciliation of interest on a number of criteria which measure their effectiveness ${ }^{27}$. In terms of costs, satisfaction with the outcome, the effect

26 J. Bondurant, Conquest Of violence, New Jork 1988.

27 W. Ury, J. Brett, S. Goldberg, Getting disputes resolved, San Francisco 1988. 
on the relationship between the parties and the likelihood of recurrence of the conflict, they find power to be the least effective and also the most costly method of dispute resolution. It is interesting to note that, to the military, conflict resolution is equated with peacekeeping ${ }^{28}$. That is, the military focuses on what peace theorists term negative peacestopping the fighting-with little or no thought of dealing with the underlying causes i.e. building positive peace.

\section{There are ethnical, moral and spiritual reasons not to deal with disputes by force}

At the level of the heart, humankind knows that the use of force or the threat to use force is not the appropriate way of dealing with disputes. Among the seven grounds which Glenn Paige advances for the development of 'non-killing' societies' are the strong roots which this has in the spiritual heritage of humankind ${ }^{29}$.'Granted', Paige notes, 'that religions have been engaged to incite and bless unspeakable slaughter. But within each faith the main message has been to respect life and not to kill... The test need not rest only upon selected scriptural passages, but needs to be seen in light of the teachings as a whole, and in the lives of the faithful in each tradition who have found inspiration for a non-killing commitment.' In addition, in its better forms, religion rejects the demonization of the enemy to make them appear more

28 D.O. Igwe, Inclusive Education and Criminality: A Challenge to the National Open University of Nigeria, „Chorzowskie Studia Polityczne Journal" 2014, Vol. 8, No. 1, pp. 219-235.

29 G. Paige, To leap beyond yet nearer bring: from war to peace to nonviolence to no killing, "International Journal of Peace Studies” 1997, Vol. 2, No. 1, pp. 97-108. 
evil, less human and therefore psychologically easier to kill. A related concept is Gandhi's insistence on the need to use moral means in order to achieve moral ends. If violence is used to achieve 'peace,' its use will corrupt the victor so as to make meaningful peace unattainable. Incidentally, in terms of international status among African countries, there is an incompatibility between being regarded as a peacemaker and maintaining a high level of militarization ${ }^{30}$.

\section{There are cost effective alternatives to the military}

The military is not the only way of achieving security and, this book emphasizes, it is no longer a cost effective way of doing so, if it ever was. Eight alternative ways of achieving security are presented in chapters 2 to 9 inclusive, each of which is likely to be more effective and less costly than the current military approach.

\section{Can the military be transformed?}

Yes. The military can be transformed. An entrench system of institutionalisation, constitutionalism and professionalism are pivotal if the military is to be transformed. These tripled strategies connect human security and human rights as fundamental components. In this connection, the question of abuse and subversion of professional mandate are institutionally address instead of personalisation. However, it must be emphasized, when the constitution determines what institutions do, personalisation of conflict and security issues

30 G. Harris, The incompatibility of peacemaking and military power, „South African Journal of International Affairs” 2001, Vol. 8, No. 1, pp. 67-74 . 
will not exist. This can only happen if there are changes in mission statements and the like; it is all about whether the ethos of dealing with conflicts by force has changed. These ethos are tied to the mandate provided by the constitution. Also, notable, are some who would argue that, given its very nature, the military is completely incompatible with democratic principles and cannot be transformed:

People do not ordinarily relish the idea of killing other people... Yet, stripped of the pomp and ceremony, of the uniforms and rituals, that is exactly what militaries are all about. Soldiers must be ready to kill or killed or militaries cannot do what they have been designed to do. Military training... is very much a process of social and psychological conditioning, designed to take away their individuality and train them to do what they are told. There is no room for questioning authority, no place for free and open debate... it is difficult to see how militaries could be effective if they were not authoritarian organizations... It is therefore very difficult for truly democratic political systems to develop and prosper in militarized societies ${ }^{31}$.

To others, it is the type of military which matters, at least in terms of its economic impact. Scheetz argues that the "negative economic impact of military expenditure is the result of a strategically offensive military posture. For mediumsized Latin American countries like Argentina, he argues that such a posture is 'military impossible to sustain, economically ruinous, and diplomatically destructive of regional stability" 32 .

31 J. Dumas, The role of demilitarization in promoting democracy and prosperity in Africa, [in:] Arming the South, Palgrave, eds. J. Breuer, J. Dunne, London 2002, pp. 15-33.

32 T. Scheetz, military expenditure and development in Latin America, [in:] Arming the south, eds. J. Breuer, J. Dunne, London 2002, pp. 51-70 . 
He goes on to argue that there are alternative, lower cost strategies - particularly non-offensive defense - which may make the military a positive influence on economic growth.

There are elements of both these opinions in BICC's peace by peaceful means, in which he argues not for the abolition of the military but to give it new tasks ${ }^{33}$. To Galtung, the military has developed a range of 'very bad habits' but also has virtues such as 'good organization, courage, willingness to sacrifice. The bad habits have to go; not necessarily the military, and certainly not the virtues'. He goes on to recommend some of the alternatives discussed elsewhere in this book - non - offensive defense, the development of the skills of nonviolent conflict resolution and the use of civilian peacekeepers.

Galtung is optimistic that the military can be transformed. The long term goal is the abolition of war as an institution, like the abolition of slavery and colonialism as institutions - an entirely realistic goal, but demanding, difficult - and absolutely necessary'. To others, including a number of the contributors to this book, the military is by definition inherently violent and incapable of transformation.

\section{In conclusion}

This article concludes that militarisation in Sub-Saharan Africa is not by choice but emerges from supportive local concerns connected to external impositions.

33 Bonn International Center for Conversion (BICC), conversion survey, global disarmament, de-military and demolition, BICC, Bonn 2000. 


\section{Recommendation}

Home grown solution has always work perfectly to provide the best value because to every conflict are some contextual nuances. Except these peculiarities are engaged and addressed sustainable peace could elude.

Military action must be the last option particularly only when human security approach is exhausted.

\section{Bibliography}

Batchelor P., Cock J., Mckenzie P., Conversion South Africa in the 1990s: defense downsizing and human development challenges, Group for Environmental Monitoring and Bonn International Centre for Conversion, Johannesburg-Bonn 2000.

Benoit E., Growth and defense in developing countries, „Economic Development and Cultural Change" 1978, Vol. 26, No. 2.

Bondurant J., Conquest of violence, New Jork 1988.

Bonn International Center for Conversion (BICC), Conversion survey, global disarmament, de-military and demolition, Bonn 2000.

Butler L., The false god of nuclear deterrence, „Global Dialogue" 1999, Vol. 1, No. 2.

Dumas J., The role of demilitarization in promoting democracy and prosperity in Africa, [in:] Arming the South, eds. J. Breuer, J. Dunne, London 2002.

Harris G., The incompatibility of peacemaking and military power, "South African Journal of International Affairs" 2001, Vol. 8, No. 1.

Human Rights Watch, Military revenge in Benue: a population under attack, Nigeria 2002, http://hrw.org/reports. 
Human Rights Watch, The destruction of Idi and ra pe in Choba, December 22, 1999, HRW background report, www. Hrw.org/press/1999.

Igwe D.O., Abubakar L.A., Gender and Peace Process in Nigerian Security Architecture, „African Journal for Security and Development" 2019, Vol. 2, No. 4.

Igwe D.O., Inclusive Education and Criminality: A Challenge to the National Open University of Nigeria, "Chorzowskie Studia Polityczne Journal" 2014, Vol. 8, No. 1.

Igwe D.O., Inclusive Education and Criminality: A Challenge to the National Open University of Nigeria, "Chorzowskie Studia Polityczne Journal” 2014, Vol .8, No. 1.

Igwe D.O., Social Conflict, Security and Peace Building in the Information Communication Age, "Chorzowskie Studia Polityczne Journal” 2013, Vol. 6, No. 1.

International Institute for Security Studies, The military balance 2000/2001, London 2000.

International Rescue Committee, Mortality study, eastern Democratic Republic of Congo, 2002, www.their.Org/ mortality/cfm.

Lukham R., Ahmed I., Muggah R., White S., conflict and poverty in Sub-Saharan Africa: an assessment of issues and evidence, Institute of Development Studies, University of Sussex Working Paper No. 128, 2001.

Mantzikos I., "A report on the Boko-Haram attacks in Nigeria and neighboring countries: A chronology of attacks", perspectives on terrorism, 8.12.2014.

Morgan W., Number of Nigerians displaced by Boko-Haram increases to 2.1 million, 2017, www.ibtimes.com/ international-organisation-for-migration2083797 (Retrieved on $9 / 4 / 2017)$. 
Paige G., To leap beyond yet nearer bring: from war to peace to nonviolence to no killing, "International Journal of Peace Studies" 1997, Vol. 2, No. 1.

Peter P.J., (2012) “The Dangerous 'Pragmatism' of Al-Qaeda in the Islamic Maghreb, "Journal of the Middle East and Africa" 2012, Vol. 2.

Pruitt D.G., Rubin J.Z., Social Conflict: Escalation, Stalemate, and Settlement, New York 1986.

Robert J., (1991) Do preparations for war increase or decrease international security?, [in:] The long postwar peace, ed. C. Kegley, Harper Collins 1991.

Salkida A., Counting the cost of Boko Haram crisis, 2018, http://desertherald.com/counting-the-cost-of-BokoHaram-Crisis/.

Scheetz T. (2002) military expenditure and development in Latin America, [in:] Arming the south, eds. J. Breuer, J. Dunne, London 2002.

Siegel L.J., Criminology: Theories, Pattern and Typoligies, $11^{\text {th }}$ edition, Belmont, CA: Wadsworth Cengage Learning.-states (19.08.2007).

Stockholm International Peace Research Institute, Military expenditure, “SIPRI. Yearbook 2000” 2000.

United Nations Development Programme, Annual, human development report, New York 1994.

Ury W., Brett J., Goldberg S., Getting disputes resolved, San Francisco 1988.

\section{Abstract}

Globally, demilitarisation averse to militarisation connects human security (human capital) model as opposed to physical security that dislodge seating government, invade community, colonise or intimi- 
date human society is not strange. However, while in most African societies the citizens and the state grapple with surging insurrection and insurgent, the largely reactionary response away from intelligent based pre-emptive military action has compounded strife and complicated peace process. The economic, social, political and infrastructural cost implication of mismanaging civil unrest by some military establishment is undesirable. Drawing from the foregoing affirm the need for demilitarisation that deepens sustainable human security option. This option explores human capital, capacity and capability to unleash creative engagement and innovative compromise that provides common ground that does no harm to the interest of the contending parties. The military in these jurisdictions is a professional democratic organisation completely subservient to civil rule. Contrasting the case of African society, militarisation is so rooted that their stake in governance is unquestionable and largely compounds and complicates peace process reinforcing insurgency. This has often undermined leadership succession processes setting democracy, good governance and sustainable development in disarray in Sub-Saharan Africa. How? Cost of governance over blotted, entrenched personality politics transforming into godfatherism and surrogate servitude among incumbent and serving public office holders. This negates populist democratic doctrine. Arising from this intelligible disconnect is the concerns to examine the demilitarisation process against Insurgency and conflict of interests in sub-Saharan Africa. Using human security and might make war perspectives and relevant cases content analyses, this article concludes that militarisation in Sub-Saharan Africa is not by choice but emerges from supportive local concerns connected to external impositions.

Keywords: Militarisation, Insurgency, conflict of interests, demilitarisation, Sub-Saharan Africa 